\title{
SPIS TREŚCI
}

\section{Recenzje}

Игорь Н. Данилевский, Историческая текстология: учебное пособие, Москва 2018 (Norbert Mika)

Adam Izdebski, Średniowieczni Rzymianie i przyroda. Interdyscyplinarna historia środowiskowa, Kraków 2018 (Piotr Olinski)

Janusz Bieniak, Zarębowie i Nałęcze a królobójstwo w Rogoźnie, Warszawa 2018 (Marek Smoliński)

Łukasz Ćwikła, Ród Prusów w Łęczyckiem, Sieradzkiem i Sandomierskiem do XVI wieku. Rozsiedlenie - majątki kariery, Łódź 2019 (Sobiesław Szybkowski)

Marek L. Wójcik, Pieczęcie rycerstwa ślaskiego w dobie przedhusyckiej, t. 1-2, Kraków-Wrocław 2018 (Marcin Hlebionek)

Ольга А. Климкович, Формуляр старорусских и старобелорусских деловых документов XIV-XVI веков, Витебск 2015 (Maciej Waraczewski)

The Correspondence of John of Capistrano, t. 1: Letters Related to the History of Poland and Silesia (1451-1456), wyd. Paweł Kras, Halina Manikowska, Marcin Starzyński, Anna Zajchowska-Bołtromiuk [współpr. Maria Koczerska, Marek Daniel Kowalski, Mieczysław Mejor, Letizia Pellegrini, Stephen Rowell, Filippo Sedda], thum. na ang. Stephen Rowell, Warsaw-Lublin 2018 (Anna Skolimowska)

Pontyfikat Erazma Ciołka, wyd. ks. Szymon Fedorowicz, Kraków 2019 (Maria Starnawska)

Gdańska kronika Bernta Stegmanna (1528), koment. i wyd. Julia Możdżeń, współpr. Kristina Stöbener, Marcin Sumowski, Torun 2019 (Piotr Okniński)

Jakub Niedźwiedź, Poeta i mapa. Jan Kochanowski a kartografia XVI wieku, Kraków 2019 (Roman Krzywy)

Lustracja cel i myt małopolskich z 1565 roku, wyd. Bożenna Wyrozumska, współpr. Marcin Starzyński, indeksy oprac. Patrycja Wiencierz, Kraków 2019 (Marek Ferenc)

Lustracja województwa podlaskiego 1602 roku, wyd. Michał Sierba, Warszawa 2017 (Emil Kalinowski) 300

Magdalena Piskała, Polski świat znaków. Studia o herbarzu Szymona Okolskiego, Warszawa 2017 (Jakub Rogulski) .... 303

Agnieszka Pawłowska, Ikonografia godet cechowych na Pomorzu brandenbursko-pruskim, Szczecin 2019 (Tomasz Katuski) 


$\begin{array}{rrrrr}\mathbf{R} & \mathbf{C} & \mathbf{N} & \mathbf{Z} & \mathbf{E} \\ & & & \text { Studia Źródłoznawcze, t. LVIII, 2020 } \\ & & & \text { ISSN 0081-7147 } \\ & & & \text { e-ISSN 2451-1331 }\end{array}$

И[горь] Н. Данилевский, Историческая текстология: учебное пособие, Издательский дом Высшей школы экономики, Москва 2018, ss. 557.

Autor książki jest rosyjskim historykiem, specjalistą w zakresie hermeneutyki źródłowej, znawcą dziejów dawnej Rusi (do końca XVI w.), a zarazem profesorem i kierownikiem Katedry Historii Idei i Metodologii Nauk Historycznych Wydziału Historii Wyższej Szkoły Ekonomicznej w Moskwie, a od 2016 r. członkiem Centralnej Komisji ds. Atestacji przy Ministerstwie Nauki i Szkolnictwa Wyższego Federacji Rosyjskiej, czyli organu przyznającego stopnie naukowe i tytuły w tym kraju. Pracę magisterską pt. Metoda datowania faktów historycznych obronił w 1975 r. na Państwowym Uniwersytecie w Rostowie. W 1981 r. został kandydatem nauk historycznych na Państwowym Uniwersytecie im. Michaiła W. Łomonosowa w Moskwie, broniąc dysertację pt. Chronologia źródet pisanych a metoda datowania faktów historycznych. Stopień naukowy doktora nauk historycznych uzyskał w 2004 r. na podstawie pracy pt. Podstawy hermeneutyki studiowania tekstów latopisarskich. Wymiernym owocem jego zaangażowania na polu naukowym i znakomitego warsztatu pisarskiego jest ponad 170 publikacji, w tym kilkanaście pozycji książkowych, przyjmowanych w środowisku historycznym w Rosji (choć nie tylko) z niesłabnącym zaciekawieniem i uwagą.

Zainteresowania Autora koncentrują się wokół badań nad tekstami literackimi doby panowania dynastii Rurykowiczów na Rusi: przede wszystkim dawnych latopisów, sprawozdań z przebiegu wydarzeń dziejowych, różnego rodzaju pouczeń, utworów hagiograficznych, traktatów teologicznych itp. Na podkreślenie zasługuje fakt, że Autor jest przedstawicielem nowej rosyjskiej szkoły historycznej, w miarę odważnie dystansującej się od zakorzenionych w literaturze naukowej mitów i stereotypów, niekiedy sięgających jeszcze średniowiecza, które następnie usiłowano podsycać w czasach carskich, a nawet w poprzedniej formacji społeczno-ustrojowej, żeby nie powiedzieć w obecnej dobie. Ostrożny krytycyzm wspomnianego Badacza wobec zideologizowanych i przesiąkniętych pisarskimi emocjami staroruskich utworów dał jemu i jego uczniom perspektywy bardziej obiektywnej, a co za tym idzie ciekawszej interpretacji dziejów swojej ojczystej ziemi.

Recenzowana książka składa się z przedmowy, wstępu, trzech rozdziałów podzielonych na siedem części, krótkiego podsumowania odnoszącego się do wykorzystywanych w procesie rekonstruowania wydarzeń historycznych informacji naukowych, czternastu dodatków czy też aneksów zawierających treści odnoszące się do dziejów dawnej Rusi, trzech wykazów: źródeł historycznych, literatury przedmiotu, specjalistycznych terminów i nazw, a także indeksu osób. Jej recenzentami byli dwaj znani naukowcy rosyjscy: profesor Jewgenij W. Anisimow (kierownik naukowy Instytutu Piotra Wielkiego przy Wydziale Programów Naukowych Sankt Petersburga, a zarazem kierownik naukowy Międzynarodowego Historyczno-Kulturowego Uniwersytetu dla Rodaków Mieszkających za Granicą z siedzibą w Sankt Petersburgu) oraz doktor nauk historycznych Olga I. Togojewa - pracownik naukowy Instytutu Historii Powszechnej Rosyjskiej Akademii Nauk w Moskwie.

Autor sięgnął po 94 edycje źródłowe i ponad 750 opracowań naukowych. O wyjątkowym charakterze publikacji Igora N. Danilewskiego nie decyduje jednak liczba wykorzystanych przez niego przekazów i prac historycznych, ale treść recenzowanej książki, którą śmiało można nazwać nowatorską w swojej koncepcji na tle historiografii rosyjskiej. Po raz pierwszy w tym kraju tekstologia historyczna została zaprezentowana jako odrębna metoda badań i podniesiona do rangi samodzielnej dyscypliny. Książka ma służyć jako jej podręcznik. Autor szczegółowo omawia zagadnienia teoretyczne związane z definiowaniem wykorzystywanego materiału historycznego jako subiektywnego źródła informacji retrospektywnych. Usiłuje także przedstawić czytelnikowi podstawowe terminy prezentowanej przez siebie dyscypliny i uzmysłowić, czym różni się tekstologia historyczna od klasycznej tekstologii filologicznej, widocznej m.in. w pracach Aleksieja A. Szachmatowa, Nikołaja P. Lichaczewa, Michaiła D. Prisełkowa, Jakowa S. Lur’iego, a spośród współczesnych lub niemal współczesnych: Dmitrija S. Lichaczewa lub Andrieja L. Nikitina. Rosyjski naukowiec stara się także pokazać praktyczne stosowanie procedur tekstologicznych w odniesieniu do różnych źródeł historycznych, jak również prześledzić ścisły związek między przedmiotem swoich badań a naukami pomocniczymi historii. Konieczne - w jego rozumieniu - staje się oddzielenie faktów historycznych od „opakowania”, w którym były podawane na kartach średniowiecznych i wczesnonowożytnych źródeł, a którym to „opakowaniem" była wszechobecna ideologia, głównie religijna. Wszak twórcy ówczesnych przekazów rekrutowali się głównie spośród przedstawicieli stanu duchownego i dobrze znali teksty biblijne, podobnie jak pisma Ojców Kościoła. Oczywiście religijny podtekst nie był jedynym czynnikiem, który towarzyszył staroruskim autorom (latopisarzom, hagiografom) w procesie tworzenia źródła. Wpływ na ich pisarstwo miały również prywatne przekonania i poglądy polityczne, balast osobistych doświadczeń, a także otoczenie, w którym działali. 
Szczególne miejsce w recenzowanej książce zajmuje fragment, liczący aż czternaście aneksów, zawierający tekstologiczną analizę epizodów historycznych odnoszących się do dziejów dawnej Rusi. Na ich przykładzie rosyjski historyk ukazuje, jak można stosować wprowadzoną przez siebie metodę badań. Aneksy dotyczą takich zagadnień (kazusów) jak: 1) wschodniosłowiańskie „związki plemienne”, 2) słowiańskie, po kądzieli, pochodzenie pierwszych władców ruskich, 3) ,przeklęty” książę Światopełk a Antychryst, 4) Ewangeliarz Ostromira, 5) tzw. Izbornik Światosława z 1076 r., 6) problem trębaczy w Latopisie radziwiłłowskim, 7) postać Kuzmiszcza (Kuźmy) Kijanina, 8) Słowo o wyprawie Igora - wiarygodność przekazu, 9) bitwa nad Kałką w 1223 r., 10) zmagania wojenne nad Newą w 1240 r., 11) zbrojne starcie na jeziorze Pejpus w 1242 r. - mit lodowego pobojowiska, 12) bitwa na Kulikowym Polu w 1380 r., 13) św. Siergiej Radoneżskij, 14) oprycznina Iwana Groźnego a „nowa” Golgota. Czytając wspomniane wyżej kazusy, można stwierdzić, że Autor profesjonalnie poradził sobie z ich wnikliwą interpretacją, dając czytelnikowi możliwość szerszego spojrzenia na prezentowany problem. Nie oznacza to naturalnie, że podana przez rosyjskiego historyka wykładnia jest jedynie słuszna i rości sobie pretensje do ostatecznego podsumowania zagadnienia.

Dla przykładu, można polemizować, czy wzmiankowana w Powieści minionych lat, a także w zależnych od niej ruskich latopisach, „пустыня межю Ллхъ1 и Чехы”, gdzie po wypędzeniu z Rusi w 1019 r. miał umrzeć „przeklęty” książę Światopełk, zięć Bolesława Chrobrego, jest tylko literacką metaforą pobożnego prawosławnego kronikarza, oznaczającą ponure miejsce wygnania i ostatniego spoczynku grzesznego władcy na niepoświęconej, ,pustej” ziemi, gdzieś na antypodach nieznanego mu świata? Warto wspomnieć o najnowszych ustaleniach polskich i czeskich badaczy (Marek Mika, Šárka Bělastová), którzy wyraźnie wskazują, że we wczesnym średniowieczu polsko-czeskie pogranicze było pozbawionym osadnictwa pustkowiem. Rozciągające się na tym terenie Sudety stanowiły rozległe pasmo wysokich, skalistych wzniesień, które tylko w dolnych partiach porastały gęste puszcze, zresztą również niezamieszkałe lub rzadko zamieszkałe przez człowieka. Tak w każdym razie opisują ten teren kronikarze, na czele z Gallem Anonimem. Pomocne w ustaleniu faktycznego stanu rzeczy mogą być ponadto prowadzone od wielu już lat badania archeologiczne po obu stronach polsko-czeskiej granicy. Występujące punktowo na tym obszarze wyziewy z wód termalnych, nasączone siarczanami i innymi ulatniającymi się związkami chemicznymi, wydzielają niekiedy nieprzyjemny zapach. Stąd może zapiska we wspomnianej już Powieści minionych lat, że wokół grobu księcia Światopełka unosi się „смрадъ золъ”. Niekoniecznie więc musi tutaj chodzić o alegoryczne ukazanie śmierdzącej woni unoszącej się z piekielnych otchłani, gdzie przebywa po śmierci wspomniany wyżej ruski władca, stylizowany na biblijnego Antychrysta, jak zdaje się proponować Autor recenzowanej pracy.

Igor N. Danilewski do każdego z poruszanych problemów stara się podchodzić rzetelnie. Przeprowadza rzeczową krytykę źródeł i ukazuje poglądy różnych historyków na to samo zagadnienie. Pozwala mu na to jego głęboka erudycja i wnikliwość prowadzonych badań. Swoje opinie wyraża zaś nad wyraz ostrożnie. Tak m.in. przedstawia się kwestia bitwy na Kulikowym Polu w 1380 r., wokół której już w średniowieczu narosło wiele legend, a która dla Rosjan jest podobnym symbolem, jak dla Polaków Grunwald. Podchodząc do problemu, Autor stara się nie tyle ustalić fakty związane z tym wydarzeniem, ile oddzielić je od towarzyszącej im ideologii, jakże potrzebnej Moskwie w dobie podporządkowywania poszczególnych księstw ruskich i zmagań z tatarskim jarzmem. Stąd sięga po źródła historyczne zredagowane w różnych krajach i kręgach społecznych, których narracja nie zawsze jest ze sobą spójna, a która stanowiła i stanowi dla badaczy podstawę do formułowania najprzeróżniejszych poglądów, niejednokrotnie ze sobą sprzecznych. Stosując proponowaną przez siebie metodę badań, Autor usiłuje przybliżyć okoliczności powstania konkretnego przekazu, postać jego twórcy, zasób posiadanej wiedzy, społeczny wydźwięk, jaki średniowieczny pisarz chciał osiągnąć, redagując swoje dzieło, a nawet różnice w treści zachowanych manuskryptów tego samego utworu. Biorąc pod uwagę wszystkie te czynniki, obraz bitwy na Kulikowym Polu, jaki rysuje się przed oczami czytelnika (badacza) po lekturze recenzowanej publikacji oraz wyobrażenie powstające po przeczytaniu którejkolwiek z klasycznych monografii o wydarzeniach z $1380 \mathrm{r}$. mogą być nieco rozbieżne. Na pewno natomiast pozwala to gruntowniej zgłębić poruszaną problematykę i formułować własne wnioski na ten temat.

Książka - co już powiedziano wcześniej - jest podręcznikiem. Z założenia więc stawia czytelnikowi pytania, zmuszając poniekąd do odpowiedzi na nie, a tym samym do weryfikowania utrwalonych już poglądów, ukształtowanych po lekturze wcześniej przeczytanych dzieł. Takie stawianie sprawy niekoniecznie musi się spotykać z akceptacją całego środowiska historycznego, jest jednak konieczne dla dalszego postępu badań. Pozostaje więc wyrazić nadzieję, że publikacja I.N. Danilewskiego, nowatorska w swym założeniu na tle rosyjskiej historiografii, pobudzi naukowców i studentów zajmujących się badaniami nad dziejami dawnej Rusi do odważnego i kompetentnego podejmowania stawianych przed nimi zagadnień. Z uważnej lektury książki mogą też skorzystać zainteresowani tekstologią historyczną badacze przeszłości innych krajów, o ile tylko znają język rosyjski. Na końcu docenić należy starania Domu Wydawniczego Wyższej Szkoły Ekonomicznej w Moskwie za estetykę książki, wyrazisty druk, dobry papier i twardą okładkę dzieła.

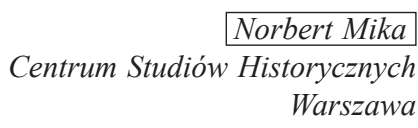




\section{Adam Izdebski, Średniowieczni Rzymianie i przyroda. Interdyscyplinarna historia środowiskowa, Towarzystwo Wydawnicze Historia Iagellonica, Kraków 2018, ss. $259+2$ nlb., 15 ss. tablic}

Historia środowiskowa jest uznawana za dyscyplinę stosunkowo młodą. Nazwa po raz pierwszy została użyta w 1969 r. Swoimi korzeniami sięga ona jednak początków historii jako uniwersyteckiej dyscypliny naukowej. Sposoby traktowania i wykorzystywania przez człowieka środowiska naturalnego wpisują się w jedno z najważniejszych zjawisk cywilizacyjnych i tym samym były one stałym przedmiotem badań historycznych. Pojawienie się historii środowiskowej jako zdefiniowanej odrębnej dyscypliny jest wyraźną reakcją na powstające zagrożenia wynikające ze sposobu traktowania środowiska naturalnego przez człowieka i konieczną refleksją nad postępowaniem człowieka wobec przyrody. W praktyce badawczej jest dyscypliną wymagającą, ze względu na swój interdyscyplinarny charakter. Do najtrudniejszych, a zarazem niezwykle ciekawych należą badania wykorzystujące jednocześnie metody z nauk humanistycznych i ścisłych. Wymaga to zwykle badań zespołowych, niemożliwe jest bowiem wykonywanie tak różnych badań przez przedstawicieli jednej dyscypliny. Uczestnictwo w takich zespołach badawczych pozwala jednak zarówno humanistom, jak i przedstawicielom nauk ścisłych na poszerzanie własnego spektrum naukowego i wykorzystanie tego w swoich badaniach. Jak się wydaje, chętniej czynią to humaniści. Z takim przykładem spotykamy się w przypadku recenzowanej książki Adama Izdebskiego.

Problemem badawczym sformułowanym w recenzowanej monografii jest ustalenie zakresu ciągłości i zmian w systemie społeczno-przyrodniczym Bizancjum w późnym antyku i średniowieczu w odniesieniu do czasów Cesarstwa Rzymskiego. Przyroda jest traktowana nie tylko jako przedmiot działań ludzkich, ale również jako aktywny uczestnik zachodzących zmian, który potrafi wpłynąć na charakter ich przebiegu. Z perspektywy zastosowanych metod na plan pierwszy wysuwa się wielowarstwowa interpretacja różnorodnych źródeł, wśród których źródła pisane są tylko jednym z rodzajów. Stała w toku narracji jest refleksja nad tym, jakie pola interpretacyjne są dozwolone dla poszczególnych grup źródeł i pozyskanych z nich danych oraz jak dalece można je łączyć, formułując ostateczne wnioski. Do najciekawszych wątków recenzowanej monografii należą zagadnienia źródłoznawcze. Szukanie informacji, czy mówiąc językiem nauk ścisłych, gromadzenie danych pozwalających na podawanie ustaleń odnoszących się do zmian środowiskowych na terenach bizantyńskich w znacznej części wykracza poza zakres źródeł wykorzystywanych zwykle przez historyków. Autor wskazuje na możliwości interpretacyjne dzięki wykorzystaniu danych pochodzących ze źródeł przyrodniczych i konfrontowaniu ich ze źródłami pisanymi, archeologicznymi i dotychczasowymi ustaleniami literatury przedmiotu.

Monografia została podzielona na dwie części. Pierwsza może być traktowana jako wprowadzenie do historii środowiskowej, mimo że jest ona w znacznej mierze dostosowana do potrzeb badań dotyczących Bizancjum przedstawianych w drugiej części. W rozdziale pierwszym tej części Autor omówił dorobek historiografii amerykańskiej, co wynika z faktu, że właśnie w Stanach Zjednoczonych została zdefiniowana dyscyplina nazywana historią środowiskową. Jako miejsce jej narodzin A. Izdebski wskazał Uniwersytet Kalifornijski w Santa Barbara i aktywnego tam pod koniec lat 60. XX w. Rodericka Nasha. Omówione zostały najważniejsze książki, które określiły kierunek, w jakim rozwinęła się ta dyscyplina. Są to m.in.: Columbian Exchange Alfreda Crosby'ego, Changes in the Land Williama Cronona oraz Donalda Worstera Dust Bowl. The Southern Plains in the 1930s. Znalazł się w tych pracach opis wielorakich związków i zależności między człowiekiem a przyrodą, pojawiły się silne wskazania na destrukcyjny aspekt aktywności ludzi, a także, co jest bardzo ważne również z perspektywy badań A. Izdebskiego, przyroda stawała się w nich aktywnym uczestnikiem procesu dziejowego. W kolejnych pracach amerykańskich przyroda była opisywana jako ważne źródło energii, co było wyraźnie widoczne zwłaszcza w opracowaniach dotyczących rzek (m.in. Theodore Steinberg, Richard White). A. Izdebski zdefiniował ten zakres tematów badawczych jako badania nad „technologizacją” przyrody. Ważne miejsce w tym nurcie refleksji naukowej zajmowały miasta, co doprowadziło do opracowania tzw. ekobiografii miejskich. Wreszcie Autor wskazał na zainteresowanie historyków amerykańskich dziejami parków narodowych i kwestiami ochrony przyrody, na znaczenie dla kształtowania środowiska przyrodniczego ścierania się różnych kultur w przypadku Ameryki oraz na podjęcie przez historyków amerykańskich zagadnień z historii środowiskowej innych krajów, zwłaszcza Chin i Rosji, a także dawnych wielkich imperiów.

W rozdziale drugim został omówiony dorobek historiografii europejskiej na tym polu. A. Izdebski podkreślił, że jest on zdecydowanie bogatszy i bardziej różnorodny, zarówno pod względem dobieranych zagadnień, jak i stosowanych metod. Wyjaśniając przyczyny tego stanu rzeczy, poza oczywistą różnorodnością wynikającą z narodowych tradycji badawczych i odmiennych doświadczeń historycznych oraz różnic językowych, Autor słusznie wskazał także na inną strukturę europejskiego świata akademickiego w porównaniu ze Stanami Zjednoczonymi. Omówienie dorobku europejskiego zaczął od przedstawienia pokrótce polskiej szkoły Franciszka Bujaka, która miała na celu powiązanie rozwoju gospodarczego ze zjawiskami ekstremalnymi. To sformułowanie jest chyba nieco bardziej adekwatne od użytego przez A. Izdebskiego określenia „katastrofy naturalne" (s. 40), nawet jeśli zostało przejęte bezpośrednio z prac takich autorów wyrosłych w tej szkole jak Antoni Walawender lub Stanisława Namaczyńska. Autor zwrócił przy tym uwagę, mimo wielu zależności, na podstawowe różnice, jakie istnieją między historią środowiskową a geografią historyczną. Rozpoczęcie od wskazania na badania prowadzone w kręgu F. Bujaka należy uznać za w pełni uzasadnione. Wielokrotnie podkreślano nowatorstwo tych badań w skali europejskiej w tamtym czasie. W przypadku Francji zasadniczy wpływ na rozwój historii środowiskowej miała szkoła „Annales”. Szczególną uwagę A. Izdebski poświęcił Fernandowi Braudelowi i jego klasycznemu dziełu Morze Śródziemne i świat śródziemnomorski 
w epoce Filipa II. Wskazał również na dorobek austriacki w ramach Umweltgeschichte oraz skandynawski, natomiast raczej skromnie zostały potraktowane prace niemieckie, całkowicie zaś pominięto inne kraje. Trudno z tego faktu czynić jednak zarzut. Racjonalnym w przypadku ujęcia syntetycznego wydaje się wskazywanie wyłącznie na wiodące osiągnięcia. W dalszej części A. Izdebski skupił się na przedstawieniu początków i dróg rozwoju klimatologii historycznej, omawiając prace klasyków tej dyscypliny, jak Emmanuel Le Roy Ladurie czy Christian Pfister. W tej części znalazło się miejsce na przedstawienie badań klimatologicznych, nad katastrofami oraz środowiskowych w Niemczech, w tym w Darmstadt czy w Lipsku (Gerrit J. Schenk, Dieter Schott, Martin Knoll, Martin Bauch). Jeden akapit został poświęcony badaniom brytyjskim, które wyrosły w wyniku doświadczeń kolonialnych. Porównując dorobek amerykański i europejski historii środowiskowej, A. Izdebski zauważył, że w Stanach Zjednoczonych można mówić o ustalonej tradycji historiograficznej, natomiast w Europie w ramach takiego określenia jest rozumiany raczej zakres zagadnień traktowanych bardzo różnorodnie w ramach różnych dyscyplin i tradycji badawczych. Stałym problemem przy tego rodzaju zarysach jest zdawkowe traktowanie dorobku nauki XIX-wiecznej. Należy zauważyć, że nawet jeśli nie używano wówczas nazwy dyscypliny „historia środowiskowa”, to treści przekazywane w różnych pracach, funkcjonujących na pograniczu historii i geografii, chyba w największym stopniu niemieckich, stanowią ważną tradycję badawczą dla historii środowiskowej.

W rozdziale trzecim Autor skupił uwagę na źródłach. Oczywiste jest, że w ujęciach historycznych dominują źródła pisane. Idąc za pracami Brunona Latoura i jego następców, A. Izdebski podkreślił materialność pracy badawczej. Materiał jest poddawany odpowiedniej procedurze badawczej i prowadzi do określonych wyników. Stosując te ogólne uwagi do nauk historycznych, A. Izdebski każe wciągać w pole badawcze nie tylko dawny tekst, źródło ikonograficzne czy archeologiczne, ale również osady jeziorne czy DNA. Tym samym nakłania do badania przeszłości z wykorzystaniem zarówno zdobyczy i warsztatu nauk historycznych, jak i np. nauk biologicznych. Pamięć o wydarzeniach jest zapisana nie tylko w źródłach pisanych, ale również np. w źródłach pochodzenia biologicznego. I nie chodzi np. tylko o resztki kostne, zresztą problem zwierząt sporadycznie jest poruszany w tej pracy, ale różnego rodzaju inne zachowane źródła, jak pyłki roślinne, słoje drzew, zmiany glebowe itp. Powstający tu problem odpowiednich kompetencji badawczych najczęściej jest rozwiązywany poprzez podejmowanie badań zespołowych, część zaś działań badawczych dotyczy zbudowania dróg komunikowania się i znalezienia wspólnego języka między różnymi dyscyplinami.

W przypadku badań nad zmianami klimatycznymi w czasach historycznych poza źródłami pisanymi i dawnymi seriami pomiarowymi wykorzystuje się również tzw. archiwa natury. Są to informacje zachowane w przyrostach drzew, w osadach jeziornych, morskich, w bagnach, torfowiskach, stalagmitach, lodowcach. Dane tego rodzaju również nie powinny być traktowane jako proste, zobiektywizowane informacje o zjawiskach klimatycznych. Należy uwzględnić wiele czynników, które wpływają na kształtowanie tego rodzaju danych. Wypada podkreślić często wyrażaną przez A. Izdebskiego ostrożność w interpretacji danych pochodzenia biologicznego. Korzystał on z prac zbierających dane odnoszące się do upraw, stanu roślinności, pogody i klimatu dla Bałkanów, Anatolii, Sycylii i Półwyspu Apenińskiego, Grecji, wybrzeża egejskiego dla lat 300-1500 n.e. Uwagi A. Izdebskiego na temat wiarygodności tego rodzaju zapisek i problemów z ich właściwą interpretacją są niezwykle istotne. Mówi on raczej o „przybliżeniach klimatycznych” budowanych na podstawie takich informacji. W żadnej mierze nie faworyzuje danych zbieranych z tzw. archiwów natury. Podkreśla ich wady, nieprecyzyjność chronologiczną, ukazywanie tylko określonego aspektu różnych zmian. Daje też wskazówki dla historyków wykorzystujących takie dane. Jedną z podstawowych zasad jest dotarcie do - jak to określił - „pierwotnej publikacji źródła”. Można przy tej okazji zauważyć, że historycy z natury rzeczy są zdecydowanie bardziej krytyczni również wobec informacji o zjawiskach pogodowych zawartych w źródłach pisanych w porównaniu np. z klimatologami, którzy często traktują różne zapiski historyczne jako niewymagające dodatkowej krytyki źródłowej.

Stosunkowo krótki rozdział czwarty, noszący tytuł System społeczno-przyrodniczy, ma być pewnego rodzaju podsumowaniem uwag zawartych w części pierwszej monografii. W istocie stanowi zdefiniowanie zamierzeń Autora - wykorzystanie bardzo różnych rodzajów źródeł, jak już wiemy, nie tylko pisanych, w celu stworzenia przybliżonego obrazu zmian na badanym obszarze w przeszłości. W rozdziale tym znalazł się podrozdział dotyczący patogentów i badań nad nimi w odniesieniu do przeszłości. Może nieco dziwić umieszczenie tego fragmentu w tym rozdziale, zawierającym ogólne treści.

Część druga dotyczy praktycznego wykorzystania wszystkich wskazywanych wcześniej rodzajów źródeł i metod badawczych w odniesieniu do Bizancjum. Rozdział piąty (czyli pierwszy części II) nosi tytuł Bizancjum z perspektywy historii środowiskowej. Korzystając z wypracowanego w Stanach Zjednoczonych modelu badań, Autor podejmuje po raz kolejny stawiane często zasadnicze pytanie: czy Bizantyńczycy byli Rzymianami? Tym razem zostało ono umieszczone w kontekście środowiskowym. Używając pojęcia „wtórnej natury”, A. Izdebski zastanawia się, na ile system społeczno-przyrodniczy zachował cechy stworzone w okresie Cesarstwa Rzymskiego, na ile zaś uległ zmianom. I w tej części Autor nie stroni od uwag metodologicznych, rozważań nad sposobem wykorzystania źródeł, przedstawiania dotychczasowych badań w ramach różnych szkół badawczych itp. Podstawowym jest założenie, że człowiek swoją obecnością wpływa na przyrodę, a w związku z tym przyroda musi zawierać świadectwa dotyczące tych wpływów. Warto jest więc szukać źródeł w przyrodzie, uznając ten wpływ, należy bowiem stwierdzić, że na podstawie źródeł przyrodniczych można wyciągać wnioski na temat społeczeństw.

W rozdziale szóstym Autor skupił się na podstawie źródłowej do badań nad wschodniorzymskim systemem społeczno-przyrodniczym. W rzeczywistości zawiera on również analizę źródeł i wnioski wypływające z tych źródeł. Na podstawie różnych danych przyrodniczych Autor podjął próbę określenia skali antropopresji, definiowanej jako wpływ człowieka na ekosystem. Pierwszy fragment dotyczy zmian klimatu. Ważnym źródłem służącym porównaniom między różnymi regionami i okresami są w tej części dane palinologiczne, pozyskane w kilku różnych miejscach na obszarze bizantyńskim. Pozwalają 
one na wychwycenie zmian w temperaturze i opadach, nie są jednak źródłami precyzyjnymi. Rekonstrukcje hydroklimatyczne wskazują na wzrost opadów ok. 500 r. w Anatolii (na podstawie stanowisk w Kapadocji i Paflagonii). Okres wilgotny trwał zapewne do drugiej połowy VIII w. Nieco inaczej było na Sycylii, gdzie okres wilgotny narastał już w ciągu wieku V i trwał do początków VIII stulecia. Na Bałkanach rozpoczął się zaś pod koniec VI w. Te regionalne różnice są czymś naturalnym.

Inną grupę danych wykorzystanych w tej części pracy stanowią źródła dendrochronologiczne, pozwalające na pozyskanie danych z dokładnością do jednego roku, a także ze wskazaniem na niektóre sezony. Autor dysponował danymi od końca XI w. Dzięki dwóm rekonstrukcjom z południowo-zachodniej Anatolii wiadomo, że okres pierwszych 150 lat według tych danych cechował się większymi opadami ekstremalnymi, natomiast ok. 1200 r. panował okres suchy (przez ok. 30-40 lat). Inaczej jednak przebiegała podobna rekonstrukcja dla terenu Macedonii.

Liczne są dane pyłkowe dla badanego obszaru. Wykorzystano je z ponad 70 stanowisk. Autor czerpał dane z publikowanych prac zawierających wyniki tego rodzaju badań (w tym również własnych) oraz z dostępnych baz danych. Można dzięki nim wskazywać m.in. na okresy intensyfikacji i słabnięcia określonych rodzajów upraw. Wpływ człowieka zaznaczał się bowiem np. rosnącym udziałem pyłku roślin uprawnych. Wyniki swoich porównań Badacz zestawiał na odpowiednich mapach. Wynika z nich np., że uprawy zbóż wcześnie, już ok. 450 r., wzrastały w Macedonii, ale zdecydowanie później w Grecji - ok. 700 r. Różnice można wskazywać również dla innych prowincji.

Kolejnym zestawem informacji były badania archeologiczne, a zwłaszcza powierzchniowe, pozwalające wyciągać wnioski na temat osadnictwa i jego charakteru na większych obszarach. Trudność w wykorzystaniu wyników badań archeologicznych wynika z ich zróżnicowania metodologicznego, stosowania różnych chronologii, a także np. odmiennego definiowania podstawowego pojęcia - jednostki osadniczej. Uwzględniając te mankamenty, A. Izdebski wskazał na stulecia IV-VII i ok. X-XII jako okresy wzmożenia osadnictwa w południowej Grecji. Po XII w. trend osadniczy wyhamował. Natomiast według danych pyłkowych spadek ten zaznaczył się dla pierwszej połowy XIV w. Ekspansję osadniczą u schyłku starożytności można też dostrzec dla Anatolii i Palestyny. Jednak w okresie późniejszym zmiany kształtowały się inaczej. W Anatolii osadnictwo się konsolidowało, co utrudnia przeprowadzanie porównań. Według niektórych danych archeologicznych intensywniejsze osadnictwo panowało w niektórych miejscach Anatolii ok. X-XI w. lub później. Te rozważania Autor zamknął wnioskami płynącymi z innych badań, opartych na archiwaliach klasztorów Świętej Góry Athos. Wynika z nich, że zintensyfikowanie osadnictwa miało miejsce w XII-XIV w. na Półwyspie Chalcydyckim i w Macedonii.

Ostatni podrozdział rozdziału szóstego, noszący tytuł Człowiek w krajobrazie: gospodarka, jest podsumowaniem tej części. Nowym wątkiem jest wykorzystanie danych dotyczących liczebności monet bizantyńskich znalezionych w ośrodkach miejskich jako wskaźnika rozwoju bądź regresu. A. Izdebski nawiązuje w tym miejscu do badań Cécile Morrisson, która zebrała informacje na temat monet i zestandaryzowała je, aby uzyskać odpowiednią platformę porównawczą. Jej wnioski są - mimo innych uwarunkowań, zależności od aktywności administracji państwowej i różnych zakłóceń wynikających z przemian życia społecznego - w dużym stopniu zbieżne z wynikami uzyskanymi ze źródeł przyrodniczych, wskazującymi na postępującą i ustępującą antropopresję.

Rozdział siódmy, noszący tytuł Przełomy społeczno-gospodarcze i rewolucje ekologiczne, jest próbą odpowiedzi na zasadnicze pytanie w monografii, jak dalece w strukturach Cesarstwa Bizantyńskiego przetrwały ślady Cesarstwa Rzymskiego z perspektywy stanu środowiska naturalnego. Autor wykorzystał przy tym wprowadzone przez Carolyn Merchant pojęcie „rewolucji ekologicznej". Zakłada się, że zmianom stosunków produkcyjnych, prawnych, kulturowych towarzyszą również zmiany w relacjach człowiek-przyroda. W przypadku Bizancjum A. Izdebski analizował dwa przełomowe okresy: połowę VII w. - czas inwazji arabskiej oraz stulecia XI-XII - czyli czas inwazji seldżuckiej w Anatolii i silnych ruchów migracyjnych. Aby uzyskać skalę porównawczą dla przemian, porównywano dłuższe okresy chronologiczne. Odnosząc się do terminu „koniec starożytności”, Autor skupił się na wieku VII. Zastanawiał się nad „reakcjami” przyrody na rozpad świata Cesarstwa Rzymskiego.

Podstawę do wyciąganych wniosków stanowią przygotowane mapy, na których umieszczono wyniki analizy materiałów palinologicznych. W przypadku Bałkanów w okresie upadku Cesarstwa Rzymskiego i w kolejnych wiekach A. Izdebski odnotował stopniowe zanikanie wpływów człowieka, zwłaszcza w centralnych Bałkanach. Autor bardzo ciekawie wyjaśnia tutaj te procesy, uwzględniając próby aktywności na tym terytorium Cesarstwa Bizantyńskiego. Odnotował zasadniczą różnicę między wybrzeżami a wewnętrznymi terytoriami Bałkanów. Wybrzeża wykazują zdecydowanie silniejszą ciągłość z dawnym imperium. Wynikało to zapewne ze stałych kontaktów z centrum Cesarstwa Bizantyńskiego.

Zasadniczy moment przemiany wyznacza granica między dwoma okresami - wiekami V-VI a VII-VIII. Widać zdecydowany zanik aktywności ludzkiej na znacznych połaciach dawnego Cesarstwa Rzymskiego: w Lewancie, Anatolii i Italii. Najwyraźniej na wielu obszarach rozpadł się rzymski system gospodarczy, wojny zaś pogłębiły ten proces. Na niektórych stanowiskach wyraźnie dostrzegalny jest związek między najazdami arabskimi a zanikiem antropopresji (np. jezioro Nar w Kapadocji). Zmiany przyrodnicze na Półwyspie Apenińskim można powiązać z wojną z Ostrogotami. Natomiast silna antropopresja utrzymywała się w VII w. na Sycylii, w południowej Grecji i na części terytoriów zachodnioanatolijskich. Największa ciągłość przyrodnicza występowała na terytoriach egejskich i Sycylii.

Zasadniczy przełom dokonał się w XI w. i wiązał się z inwazją turecką w Anatolii, porównywalną w swoich konsekwencjach z upadkiem Rzymu. Doszło do zaniku aktywności ludzkiej w wielu regionach Anatolii. Autor był w stanie wskazać te zjawiska na podstawie stosunkowo nielicznych przebadanych stanowisk. Może to być podstawą do postawienia zarzutu o wyciąganie wniosków opartych na zbyt skromnej bazie źródłowej. Z drugiej jednak strony uderzająca jest zbieżność między różnymi stanowiskami o silnej antropopresji na obszarach położonych nad wybrzeżem zachodnim a umiarkowaną bądź zanikającą antropopresją wewnątrz Anatolii i na jej wschodnich obrzeżach. Podane w opracowaniu twierdzenia zostaną zweryfikowane przez 
przyszłe badania, w tym rosnącą liczbę danych palinologicznych z różnych stanowisk, ale wiele wskazuje na to, że obecnie formułowane wnioski znajdą potwierdzenie.

Spostrzeżenie dotyczące spadku ludzkiej aktywności w XII-XV w. na zachodnim wybrzeżu zostało sformułowane na podstawie wzrostu udziału pyłków sosny. Ma to też świadczyć o kryzysie w rolnictwie. Z drugiej strony można dyskutować, na ile miarodajne jest słabe zaznaczenie się wzrostu tych pyłków na stanowiskach we wschodniej Anatolii. Należałoby uwzględnić nie tylko łatwość przenoszenia się pyłków sosnowych, ale też ogólny stan roślinności, co nie jest rzeczą prostą. Wydaje się, że więcej mówią zmiany w udziałach pyłku sosny na zachodnim wybrzeżu aniżeli nieznaczne zmiany w głębi Anatolii, które mogą świadczyć o ogólnym słabszym rozwoju tych obszarów przez cały badany okres.

Z kolei w odniesieniu do Anatolii Autor zauważa wzrost aktywności ludzkiej w jej środkowej i wschodniej części począwszy od XII w. Ma to być oznaką przemian gospodarczych, spadku znaczenia dawnych miast, natomiast wzrostu znaczenia ośrodków, które stanowiły bazę wypadową dla nowej kolonizacji i rozwoju rolnictwa. Zjawisko dostrzeżone na podstawie badań archeologicznych i palinologicznych Autor tłumaczy zachodzącymi zmianami społecznymi. Składały się na nie migracje wywołane zagrożeniem tureckim i rozpad bizantyńskiej administracji w Anatolii. Doszło do decentralizacji gospodarki. Wiejskie rezydencje, opuszczone przez arystokrację, zostały zajęte przez nowych mieszkańców, którzy również uprawiali ziemię, lecz jak stwierdzono na podstawie jednego ze stanowisk archeologicznych, zmianie uległa ich kultura materialna. W efekcie widać, że obszary zajęte przez Turków poddane zostały silniejszej antropopresji w XII-XIV w. (Anatolia wschodnia i centralna), natomiast takie rejony jak Bitynia i Pizydia stały się od końca XI w. obszarami częstych działań wojennych, co wpłynęło na zmiany środowiskowe. Podsumowując, Autor stwierdził, że inwazja seldżucka silnie oddziaływała na zmiany społeczne i przyrodnicze znaczących obszarów bizantyńskich, zrywając tym samym ich ciągłość ze światem rzymskim.

Kolejny rozdział dotyczy zmian klimatu. Autor stara się w wyważony i ostrożny sposób analizować możliwości wpływu zmian klimatycznych na społeczeństwo i gospodarkę. W strefie śródziemnomorskiej niezmiernie istotne dla rolnictwa są opady w porze zimowej. Zostały one dosyć dobrze rozpoznane. Ważne były również deszcze wiosenne, które w nadmiarze były szkodliwe dla wielu upraw, jednak zbyt słabe deszcze szkodziły innym uprawom, zwłaszcza oliwkom. Autor korzystając z danych paleoklimatycznych, skupił się na dwóch okresach - późnej starożytności i późnym średniowieczu. Celem była weryfikacja tez wskazujących na duże znaczenie zmian klimatycznych dla upadku Rzymu i Bizancjum. Autor idąc za nowszymi opracowaniami, zwrócił uwagę, że błędne jest mówienie o jednym klimacie śródziemnomorskim, należy bowiem uwzględnić różnice regionalne. Za nieuprawnione uznał również próby ścisłego wiązania zmian klimatycznych z przemianami historycznymi.

Pierwszym analizowanym elementem były opady. Zbierając ustalenia pochodzące z różnych badań, Autor stwierdził, że na terenie Cesarstwa Wschodniorzymskiego doszło do okresu suchego w IV-V w., najsilniejszego w środkowej Anatolii. W wiekach VI-VIII zapanował okres wilgotny. Na podstawie danych z niektórych regionów wydaje się, że do tej zmiany doszło dosyć raptownie. Najdłużej trwał on na Sycylii. Musiało to znacząco wpłynąć na rolnictwo i umożliwiło zwiększenie upraw zboża. Spowodowało zapewne również ekspansję osadnictwa wiejskiego. W przypadku Sycylii mogą to potwierdzać dane pyłkowe ze stanowiska w Lago di Pergusa (wzrost pyłku zboża na niekorzyść oliwki w IV-V w.). W VIII w. trend ten zanikał. Jak zauważył A. Izdebski, na Sycylii najbardziej zaznaczył się wpływ zmiany klimatu na gospodarkę rolną. Natomiast w przypadku wschodniej Anatolii czy Galilei stwierdził, że zmiana krajobrazu poprzedziła zmianę klimatu, czyli trudno wskazywać na wpływ klimatu na środowisko.

W odniesieniu do temperatury Autor skupił się na tzw. późnoantycznej epoce lodowcowej, która zapanowała na kilkadziesiąt lat, począwszy od 536 r. Nie udało się jednak w jednoznaczny sposób stwierdzić, że wpłynęło to na rolnictwo. Ciekawe jest spostrzeżenie, że wahania klimatu trwały najwyraźniej krócej i były mniejsze na obszarze egejskim. A. Izdebski uznał te tereny za społeczno-przyrodniczą oś Cesarstwa Bizantyńskiego o największych cechach trwałości.

Również dla okresu średniobizantyńskiego formułowano wnioski o klimatycznych przyczynach pogorszenia gospodarczego. W tym przypadku A. Izdebski postanowił sprawdzić tezę sformułowaną przez Ronniego Ellenbluma o związku między pogarszaniem się klimatu a osłabieniem Cesarstwa Bizantyńskiego i islamizacją Bliskiego Wschodu. Zwrócił uwagę na brak szerszego wykorzystania źródeł archeologicznych oraz pominięcie rekonstrukcji paleoklimatycznych dla Bliskiego Wschodu w pracy tego badacza. Według danych paleoklimatycznych stulecia VIII-X w Anatolii i na Bałkanach były raczej wilgotne i sprzyjające rolnictwu. Wyraźny był wzrost opadów jesienno-zimowych. Wieki XI i XII okazują się jednak mniej stabilne pod względem klimatycznym. Mogłoby to potwierdzać opinię R. Ellenbluma. Najmniej odpowiednie były warunki pogodowe w drugiej połowie XII w. Jednak trudno jest to powiązać z trendami w rolnictwie. Dane o opadach wiosennych z Macedonii i Tracji również wskazują na ich zmniejszanie się pod koniec XII w. Autor zwrócił jeszcze uwagę na związek między wybuchem wulkanu Samalas w 1257 r. a pogorszeniem się pogody w niektórych częściach Anatolii. W sumie jednak uznał, że próby wiązania zmian klimatycznych ze zmianami w okresie średniowiecza bizantyńskiego przynoszą zdecydowanie mniej zadowalające rezultaty, aniżeli to miało miejsce w przypadku późnego antyku i wczesnego średniowiecza.

Ostatni rozdział, pt. Struktury ciagłości, jest podsumowaniem dotychczasowych badań i sformułowaniem odpowiedzi na postawione na początku drugiej części pytanie. Autor stwierdził, że raczej nie należy mówić o przerwaniu ciągłości stosunków społeczno-przyrodniczych od czasów rzymskich, a raczej o ich terytorialnym kurczeniu się. Obszar egejski kontynuował trendy rozwoju aż po wiek XIII-XIV. Zmiany dotknęły np. Sycylii, co obok przemian społecznych i politycznych wyjaśniają również trendy klimatyczne, czy wielu części Anatolii. Autor zastanawia się nad przyczynami tej ciągłości. Uznaje, że niezwykle ważna była rola samego Konstantynopola. Poza tym nadal stosowano znane sposoby uprawy roli. A. Izdebski zwrócił uwagę na ciągłość infrastruktury rolniczej, a także refleksji teoretycznej. Świadectwem tej ostatniej ma być popularność „Geoponiki”, zbioru wskazówek dotyczących rolnictwa, jej tłumaczeń i zasięgu. Całość zamyka krótkie zakończenie, w którym 
Autor potwierdził swoje spostrzeżenia na temat kurczącej się ciągłości rozwoju rzymskiego systemu społeczno-przyrodniczego na terenach bizantyńskich.

Monografia A. Izdebskiego nie tylko wnosi wiele nowych ustaleń dotyczących momentów przełomowych w dziejach Bizancjum, koryguje dotychczasowe twierdzenia, ale również pokazuje nowe sposoby narracji, dzięki wykorzystaniu różnorodnych rodzajów źródeł, wśród których kluczową rolę odgrywały źródła pochodzenia przyrodniczego.

Piotr Oliński

Instytut Historii i Archiwistyki

Uniwersytet Mikołaja Kopernika

Toruń

\section{Janusz Bieniak, Zarębowie i Nalęcze a królobójstwo w Rogoźnie, Wydawnictwo DiG, Warszawa 2018, ss. $225+7$ nlb., 6 tabl. genealogicznych}

Recenzowana praca jest wynikiem wieloletnich przemyśleń Janusza Bieniaka na temat przyczyn i przebiegu zabójstwa króla polskiego Przemysła II, dokonanego 8 II 1296 w Rogoźnie. Autor skupił się nie tylko na samym zamachu, ale też na dziejach wielkopolskich rodów możnowładczych Zarębów i Nałęczy, i oskarżeniu ich przedstawicieli o udział w uśmierceniu władcy. Z fragmentami dociekań Autora na ten temat mieli okazję zapoznać się uczestnicy i słuchacze sesji genealogicznych organizowanych jeszcze w latach 90. XX w. przez toruńskie środowisko naukowe skupione wokół Janusza Bieniaka, Jana Wroniszewskiego, Jacka Hertla i innych badaczy genealogii, heraldyki i prozopografii. Na szerszą skalę nigdy jednak nie zostały one wcześniej opublikowane.

Praca w dużej mierze jest studium polemicznym. We Wstępie, pięciu rozdziałach zatytułowanych odpowiednio: Rozbieżny werdykt, Sylwetki podsądnych, Świadectwo sprawy, Przebieg wydarzeń, Narodziny oskarżenia oraz w Podsumowaniu Autor przypomniał podstawowe fakty związane z wydarzeniami rogozińskimi. Wskazał też na główne pola dyskusji toczącej się w literaturze wokół tego wydarzenia. Podobnie jak w swych innych publikacjach, nie oparł się pokusie poprawienia przyjętego w historiografii nazewnictwa związanego z pisownią imion czy w tym wypadku nazw rodów. We Wstępie zaproponował zmianę dotychczasowego sposobu zapisu nazwy rodu „Zaremba” na „Zaręba”. Argumentu dostarczyła mu w tym względzie analogia do nazwy Nałęcz, zapisywanej z użyciem samogłoski nosowej „ę” (s. 7 n.). Propozycję tę warto odnotować, choć ocenić mogą ją dopiero językoznawcy lub też historycy języka' ${ }^{1}$.

W rozdziale pierwszym (s. 9-33) J. Bieniak zajął się omówieniem prób ustalenia zleceniodawców morderstwa. Odniósł się przede wszystkim do propozycji Karola Górskiego, Kazimierza Jasińskiego i Edwarda Rymara². Za K. Jasińskim przyjął, że za morderstwo odpowiedzialni byli margrabiowie brandenburscy, wśród nich zaś Askańczycy z linii joannickiej (s. 10). Zmodyfikował przy tym stanowisko K. Jasińskiego w sprawie motywów działania margrabiów. Do tzw. planu morskiego margrabiów, który zakładał dotarcie do Bałtyku i opanowanie Pomorza Gdańskiego, Autor dodał ich dążenia do zajęcia ziem zanoteckich. Wniosek ten nasunął mu się chyba pod wpływem badań E. Rymara, od lat zgłębiającego postępy terytorialne Askańczyków na pograniczu z Pomorzem i Wielkopolską ${ }^{3}$. Tym samym z grona potencjalnych inicjatorów zamachu zostali wykreśleni inni rywale Przemysła II, którzy pojawiali się na łamach literatury przedmiotu . J. Bieniak stanął zdecydowanie wśród tych badaczy, którzy starali się uniewinnić od zarzutu udziału w zamachu na króla polskiego Zarębów i Nałęczy. Jasno w tym fragmencie wskazał, że zamierza iść dalej niż np. broniący Zarębów Władysław Karasiewicz i w ogóle zanegować możliwość udziału w zamachu poddanych Przemysła (s. 11, 16) . Ponieważ śmierć Przemysła II była klęską możnych wielkopolskich, których program polityczny w dużej mierze realizował zamordowany władca, to nikt z przedstawicieli ówczesnej elity władzy (w tym Zarębowie czy Nałęcze) nie mógł być zainteresowany uśmierceniem króla (s. 12).

Pewną część rozdziału pierwszego zajmuje polemika Autora z hipotezami E. Rymara. J. Bieniak sprzeciwił się tezie, że ze względów majątkowych i rodowych tak Zarębowie, jak i Nałęcze przeszli najpierw w XIII, a potem w XIV w. na stronę margrabiów brandenburskich (s. 18 n.). Oprotestował też możliwość respektowania praw nadanych Askańczykom przez cesarza

\footnotetext{
${ }^{1}$ Sceptycyzm wobec propozycji językowej Autora zgłosił już T. Jurek, rec.: Janusz Bieniak, Zarębowie i Nałęcze a królobójstwo w Rogoźnie, Wydawnictwo DiG, Warszawa 2018, s. 232, Rocz. Hist., 85, 2019, s. 147.

${ }^{2}$ K. Górski, Śmierć Przemysła II, Poznań 1929 (nadb. z: Rocz. Hist., 5, 1929, s. 170-200); K. Jasiński, Tragedia rogozińska 1296 r. na tle rywalizacji wielkopolsko-brandenburskiej o Pomorze Gdańskie, Zap. Hist., 26, 1961, nr 4, s. 64-104; E. Rymar, Próba identyfikacji Jakuba Kaszuby, zabójcy króla Przemysła II, w powiązaniu z ekspansją brandenburska na pólnocne obszary Wielkopolski, w: Polska - Niemcy w średniowieczu. Materialy z konferencji naukowej zorganizowanej przez Instytut Historii UAM w dniach 14-16 XI 1983 roku, red. J. Strzelczyk, Poznań 1986, s. $203-224$.

3 Zob. E. Rymar, Próba identyfikacji, s. 212 n.; tenże, Przynależność polityczna wielkopolskich ziem zanoteckich między dolną Drawą i dolna Gwda oraz Wielenia, Czarnkowa i Ujścia w latach 1296-1368, Rocz. Hist., 50, 1984, s. 39-83; tenże, Losy nadnoteckiego pogranicza wielkopolsko-nowomarchijskiego koło Drezdenka (XIV-XVI w.), „Nadwarciański Rocznik Historyczno-Archiwalny”, 12, 2005, s. 15-32; tenże, Jeszcze o datacji i okoliczności zawarcia polsko-brandenburskiego uktadu landsberskiego (gorzowskiego), „Nadwarciański Rocznik Historyczno-Archiwalny”, 18, 2001 , s. 31-43.

${ }^{4}$ Zob. T. Jurek, Dziedzic Królestwa Polskiego książę glogowski Henryk (1274-1309), Poznań 1993, s. 31 n.

${ }^{5}$ W. Karasiewicz, Działalność polityczna Andrzeja Zaręby w okresie jednoczenia państwa polskiego na przełomie XIII/XIV w., Poznań 1961, s. 8-15 i in.
} 
Fryderyka II w 1231 r. i potwierdzonych w 1295 r. przez Adolfa Nassauskiego do zwierzchnictwa nad Pomorzem zarówno przez Przemysła II, jak i polskie możnowładztwo (w tym przez Zarębów i Nałęczy) (s. 21 n.) ${ }^{6}$. Wykluczył, żeby Przemysł II, przejmując Pomorze Gdańskie od Mściwoja II, zaakceptował zobowiązania lenne przyrzeczone wcześniej (w 1269 i 1273 r.) margrabiom brandenburskim przez księcia pomorskiego. Autor w krytyce hipotez swego naukowego oponenta sięgnął jednak do pozaźródłowych argumentów - zwłaszcza przy próbie wskazania na nierówność społeczną dzielącą Przemysła II i Askańczyków brandenburskich (s. 26 n.). Przed deprecjacją roli politycznej i społecznej margrabiów należy się powstrzymać choćby ze względu na to, że zawierali oni układy lenne z teoretycznie wyżej od nich stojącymi w hierarchii feudalnej książętami (w tym pomorskimi). Gryfici podporządkowywali się margrabiom w 1236 i 1250, a Mściwoj II w 1269 i 1273 r. Ówczesną pozycję feudalną margrabiów określają małżeństwa łączące ich z przedstawicielami domów królewskich: Danii, Czech, Węgier i Niemiec czy wielu książęcych (w tym też z Piastami wielkopolskimi). Margrabia Otton III (mając wsparcie książąt saskich i brunszwickich) był w 1256 r. jednym z kandydatów stających do elekcji na króla niemieckiego. Umniejszanie pozycji feudalnej margrabiów nie wydaje się w tym względzie dobrym pomysłem.

Rozdział II (s. 34-134) poświęcono przedstawieniu sylwetek możnych najczęściej podejrzewanych o udział w zamachu (w tym Sędziwoja z Jarocina - z rodu Zarębów i Wincentego z Wielenia - z rodu Nałęczy). Zarysowano tu też historię obu rodów od początków wiadomości o jej przedstawicielach aż po XIV w. Uważam, że jest to jeden z najbardziej wartościowych fragmentów pracy. Autor skorygował w nim istniejącą wiedzę w sprawie pochodzenia Kiełcza syna Tomisławica z Szamotuł, Tomisława syna Wincentego z Wielenia, Wincentego potomka Jana z Pomorzan czy córki Tomisława z Szamotuł, żony Beniamina Zaręby z Nękanowa (s. 34-70). Wiedzę na temat genealogii Zarębów wzbogacił o wnioski dotyczące scholastyka gnieźnieńskiego Wacława czy prepozyta gnieźnieńskiego Gotpolda (obu hipotetycznie uznanych za synów Jana, cześnika Władysława Odonica). Nowe ustalenia pojawiły się też w sprawie Jarkembolda Olbrachtowica (s. 82 n.). Autor dopuścił mianowicie możliwość istnienia w rodzie Zarębów dwóch jego przedstawicieli posługujących się wspomnianym imieniem. Pierwszym miał być Jarkembold zmarły bezpotomnie po 22 XI 1282, drugim natomiast Jarkembold występujący w dokumencie Mściwoja II z 13 XII 1293. Wedle J. Bieniaka miał on być synowcem Jarkembolda Olbrachtowica. Niestety propozycja ta nie została uwzględniona w tablicach genealogicznych Zarębów umieszczonych na końcu pracy. Z nowymi wątkami i modyfikacją starszych ustaleń spotykamy się przy omówieniu genealogii i karier Berwolda z Siedlemina i Andrzeja z Ryszewa (s. 84 n., 92 n.). Autor gruntownie omówił też linię Zarębów wywodzącą się od Janka Olbrachtowica z Jarocina (s. $105-117$ i in.). Do genealogii postaci przywoływanych na kartach pracy odwołał się też w ostatnim rozdziale. Wprowadził w tym miejscu kolejną modyfikację w wiedzy na temat paranteli łączącej Nałęczy i Ostenów. Według Autora szwagrem Betkina von der Osten nie był Dobrogost, brat wojewody Wincentego z Szamotuł, ale inny Dobrogost z Szamotuł, dotychczas od niego nie odróżniany (s. 177). Wniosek ten ponownie jednak nie znalazł odzwierciedlenia w dołączonych do pracy tablicach genealogicznych.

Rozdział II jest też miejscem dyskusji prowadzonej przez Autora z tezami zaczerpniętym głównie z prac Kazimierza Jasińskiego, Jana Pakulskiego, Krystyny Górskiej-Gołaskiej, Edwarda Rymara, Marii Bielińskiej, Józefa Sporsa, Błażeja Śliwińskiego i Tomasza Jurka7. We wnioskach końcowych ponownie przebija przekonanie, że udział Zarębów i Nałęczy w zamachu na Przemysła II jest niemożliwy do przyjęcia. Decydować o tym miały: kariery przedstawicieli tych rodów przy książętach wielkopolskich z linii Władysława Odonica, a potem Władysława Łokietka, wzajemne relacje przedstawicieli tych rodów oraz negatywny stosunek do Brandenburgii (s. 126-133). Bunt Sędziwoja Zaręby z 1284 r. przeciwko Przemysłowi II, przyczyn którego Autor nie był w stanie ostatecznie ustalić (s. 35, 108, 130), nie miał większego znaczenia dla późniejszych relacji między wielkopolskim władcą i Zarębami.

W rozdziale III (s. 134-145) Autor skupił się na źródłach opisujących okoliczności śmierci Przemysła II. W ich pogrupowaniu poszedł w kierunku wyznaczonym już przez Walthera Grüneberga, Karola Górskiego, Kazimierza Jasińskiego i Bronisława Nowackiego ${ }^{8}$. Postępowanie to ma swoje zalety i wady. Do tych pierwszych zaliczyć trzeba usystematyzowanie źródeł narracyjnych i ich podział na trzy grupy. Źródła z pierwszej grupy winą za zabójstwo władcy polskiego obarczały ludzi pozostających na służbie margrabiów brandenburskich. Informacje źródłowe z drugiej grupy oskarżały o udział w morderstwie poddanych polskiego władcy. Wzmianki z trzeciej grupy wskazywały na obie ze wspomnianych grup, tak poddanych króla, jak i margrabiów brandenburskich. Wadą przyjętego rozwiązania jest brak poszukiwań przez Autora innych źródeł, do których nie dotarli wcześniejsi badacze zajmujący się sprawą morderstwa Przemysła II. Chodzi o źródła powstałe poza Polską i informacje spisane już w czasach nowożytnych, ale bazujące na wcześniejszej podstawie ${ }^{9}$. Pozwalają one w szerszym zakresie

\footnotetext{
${ }^{6}$ Zob. też E. Rymar, Przynależność polityczna, s. 80, gdzie o możliwym podporządkowaniu Drezdenka Zarębom przed zajęciem tego grodu przez margrabiów po śmierci Przemysła II.

K. Jasiński, Tragedia rogozińska, s. 90 n.; J. Pakulski, Rola polityczna Beniamina Zaremby w drugiej połowie XIII wieku, „Acta Universitatis Nicolai Copernici. Historia”, 5, 1969, s. 21-32; tenże, Ród Zarembów w Wielkopolsce w XIII wieku i na poczatku XIV wieku, „Prace Komisji Historii XI”, Bydgoskie Towarzystwo Naukowe, seria C, nr 16, 1975, s. 104-137; K. Górska-Gołaska, Dobra Natęczów w Wielkopolsce w średniowieczu, „Studia i Materiały do Dziejów Wielkopolski i Pomorza”, 15, 1984, nr 2, s. 177-218; Urzędnicy wielkopolscy XII-XV wieku. Spisy, t. 1, oprac. M. Bielińska, A. Gąsiorowski, J. Łojko, red. A. Gąsiorowski, Wrocław 1985; E. Rymar, Próba identyfikacji; J. Spors, Urzad wojewody na Pomorzu Gdańskim do początków XIV wieku, „Słupskie Prace Humanistyczne”, 4, 1985, s. 15-31; B. Śliwiński, Mikołaj Jankowic, Mikołaj Przedpełkowic i palacja kaliska w 1299 roku, Rocz. Hist., 55-56, 1989-1990, s. 133-149; T. Jurek, Średniowieczne Szamotuly i ich dziedzice, w: Szamotuly. Karty z dziejów miasta, t. 1, red. A. Gąsiorowski, Szamotuły 2006, s. 11-64.

8 W. Grüneberg, Der Ausgang der pommerellischen Selbständigkeit, Historische Studien, t. 128, Berlin 1915, s. 45-48; K. Górski, Śmierć Przemysła II, s. 3-14; K. Jasiński, Tragedia rogozińska, s. 71 n.; B. Nowacki, Przemyst II odnowiciel korony polskiej, Kraków 2007, s. 207 n.

9 Zob. J. Tęgowski, rec.: Janusz Bieniak, Zarębowie i Nałęcze a królobójstwo w Rogoźnie, Wydawnictwo DiG, Warszawa 2018, Zap. Hist., 84, 2019, nr 4, s. 246, przyp. 3. Przykładem nowożytnych źródeł czerpiących z wcześniejszej tradycji jest kronika pelplińska, o której dalej.
} 
spojrzeć na sposób rozprzestrzenia się wieści o sprawcach czy inicjatorach rogozińskiego mordu. Tych ostatnich udało się Autorowi wskazać już po prześledzeniu źródeł dyplomatycznych nawiązujących do okresu, w którym doszło do zamachu czy wydarzeń politycznych po nim następujących ${ }^{10}$.

Wśród wniosków Autora wyeksponować trzeba przynajmniej dwa. Pierwszy został podjęty w ślad za starszą literaturą, wedle której najważniejszym źródłem jest relacja Rocznika kołbackiego. Drugi dotyczył roczników z grupy małopolskiej, czyli tzw. Rocznika Traski, zrekonstruowanego kaliskiego i świętokrzyskiego, czyli rocznika mansjonarzy krakowskich. Do tego dochodziła jeszcze relacja z Katalogu biskupów krakowskich ${ }^{11}$. To w nich pojawiły się oskarżenia wskazujące nie tylko na rodzimych uczestników zamachu, ale też konkretnie na udział w zabójstwie króla Zarębów i Nałęczy. Podobny wydźwięk miały też niektóre źródła ruskie, w których jako sprawców wymieniono Zarębów i Nałęczy ${ }^{12}$. Autor stwierdził, że nie należy ufać tym relacjom (s. 140). Informacja o zamachu dokonanym przez Zarębów i Nałęczy samodzielnie lub we współpracy z „Sasami” miała więc powstać pod wpływem późniejszych wydarzeń, w kręgach niechętnych możnowładztwu wielkopolskiemu. Podobnie zostały potraktowane przez Autora źródła wspominające, że Przemysł II zginął w wyniku zamachu jego poddanych (bez konkretnej informacji, o których poddanych chodzi). Tę wersję wypadków rozpowszechniać mieli margrabiowie brandenburscy, chcący zrzucić z siebie odpowiedzialność za śmierć polskiego króla, a przynajmniej sprawę tę „,zaciemnić” na arenie międzynarodowej (s. 144). Wedle Autora wartość dla odtworzenia rogozińskich wypadków mają tylko te źródła, które wskazywały na winę czy przynajmniej inspiracje margrabiów brandenburskich. Grupę informacji w szczególny sposób budzących zaufanie J. Bieniaka tworzą przekazy współczesnego wydarzeniom rogozińskim Rocznika kołbackiego. Do tego dodać trzeba przekazy Rocznika kapituly poznańskiej (wedle J. Bieniaka kontynuowanego przez sekretarza biskupa Andrzeja Zaręby, s. 134), późniejszej Kroniki wielkopolskiej (według Autora zredagowanej, jeśli nie napisanej, przez Janka z Czarnowa), spisanej przez opata oliwskiego Stanisława Kroniki oliwskiej lub też XIV-wiecznej Kroniki z Henryka Herfordu ${ }^{13}$.

Szczególnie istotnym problem stała się próba odpowiedzi na pytanie, kim był znany z Rocznika kołbackiego Jakub Kaszuba. J. Bieniak odrzucił propozycję E. Rymara ${ }^{14}$, który próbował utożsamić Jakuba z przedstawicielami przybyłego z Rzeszy Niemieckiej i osiadłego na Pomorzu rodu Güntersberg. Autor recenzowanej pracy dopuścił identyfikację Jakuba Kaszuby z Jakubem z Wołogoszczy (czego też na pewnym etapie nie wykluczał E. Rymar). Jakub musiał być słowiańskim rycerzem. Jak chciał J. Bieniak za K. Jasińskim, oddział najemników wysłany przez Askańczyków do Rogoźna musiał w swych szeregach mieć ludzi posługujących się językiem słowiańskim.

Pod 1296 r. w Roczniku kołbackim zanotowano, że tego roku Piotr (sic!) król Polski został zabity przez jednego z rycerzy margrabiów, zwanego Jakubem Kaszubą ${ }^{15}$. Zamordowanie Przemysła II przez sługi margrabiów potwierdziła też znacznie późniejsza, bo pochodząca z 1350 r., Kronika oliwska - a więc źródło narracyjne napisane w innej filii klasztoru kołbackiego ${ }^{16}$. Choć kronika myliła margrabiego brandenburskiego odpowiedzialnego za śmierć Przemysła II, to i w niej wskazano na udział w zabójstwie ludzi służących margrabiemu. Opinia ta funkcjonowała też na innych obszarach państwa krzyżackiego ${ }^{17}$. Kronika oliwska wiązała zabójstwo Przemysła II nie tylko z działalnością sług margrabiów brandenburskich. Traktowała śmierć króla jako skutek wcześniejszego zamordowania przez Przemysła II swej żony, Lutgardy meklemburskiej.

Niektórzy badacze sądzili, że wtręt o Lutgardzie pojawił się w Kronice oliwskiej jako eksport tradycji meklemburskiej, która trafiła na Pomorze z meklemburskiego Doberanu - macierzy klasztoru cystersów w Pelplinie ${ }^{18}$. W nowożytnej kronice klasztoru pelplińskiego nie pamiętano jednak o sprawie Lutgardy, obciążając za śmierć Przemysła II bezpośrednio margrabiów brandenburskich $^{19}$. W spisanym ok. 1378 r. na podstawie tradycji funkcjonującej w klasztorze doberańskim utworze Ernesta Kirchberga wyraźnie wybrzmiało za to oskarżenie Przemysła II o spowodowanie śmierci żony ${ }^{20}$. Skoro brak tej informacji w kręgu pelplińskim, to raczej klasztor ten nie był łącznikiem tradycji meklembursko-pomorskiej²1. Może w grę wchodziły

${ }^{10}$ Regesten der Markgrafen von Brandenburg aus askanischem Hause, wyd. H. Krabbo, wyd. 5, München-Lepzig 1920, nr 1643; E. Rymar, Próba identyfikacji, s. 206; zob. też T. Jurek, Brandenburski zabór w Wielkopolsce $1296 r$. Zapoznany dokument, „Studia z Dziejów Średniowiecza”, 10, 2004 (Mieszczanie, wasale zakonnicy), s. 361-370.

${ }^{11}$ Rocznik Traski, wyd. A. Bielowski, w: MPH, t. 2, Lwów 1872, s. 849; Rocznik kaliski (rekonstrukcja), wyd. B. Kürbis, w: MPH s.n, t. 6 (Roczniki wielkopolskie), Warszawa 1962, s. 146; Rocznik świętokrzyski, wyd. A. Rutkowska-Płachcińska, w: MPH s.n., t. 12, Kraków 1996, s. 54; Katalogi biskupów krakowskich I-V, wyd. W. Kętrzyński, w: MPH, t. 3, Lwów 1878, s. 365.

${ }^{12}$ Kontynuacja Kroniki halicko-wotyńskiej w rękopisie Bundura/Jarockiego (K. 231v-232v) z wariantami z Kodeksu jermołajewskiego (k. 291v-292v), wyd. D. Dąbrowski, A. Jusupowić, w: MPH s.n., t. 16, Kraków-Warszawa 2017, s. 269.

13 Annalen des Kolsters Colbatz, wyd. R. Prümers, w: Pommersches Urkundenbuch, t. 1, wyd. 2, Stettin 1877, s. 485; Rocznik kapituly poznańskiej, wyd. B. Kürbis, w: MPH s.n., t. 6, Warszawa 1962, cap. 122, s. 53; Kronika wielkopolska, wyd. B. Kürbis, w: MPH s.n., t. 8, Warszawa 1970, cap. 159, s. 125; Chronica Oliviensis auctore Stanislao abbate Olivensi, wyd. W. Kętrzyński, w: MPH, t. 6, Kraków 1893, s. 315; Liber de rebus memorabilioribus sive chronicon Henrici de Hervordia, wyd. A. Potthast, Gottingae 1859, s. 211.

${ }^{14}$ E. Rymar, Próba identyfikacji, s. 209 n.; J. Bieniak, Zarębowie i Nałęcze a królobójstwo w Rogoźnie, Warszawa 2018, s. 147 n.

15 Annalen des Kolsters Colbatz, s. 485.

${ }^{16}$ Chronica Oliviensis, s. 315.

17 Terra Pomerania quomodo subjecta est ordini fratrum Teutonicorum, wyd. T. Hirsch, w: Scriptores rerum Prussicarum [dalej: SRP], t. 1, Leipzig 1860, s. 805.

${ }_{18}$ Zob. J. Wenta, Zaginiony rocznik oliwski z XIII/XIV wieku, Zap. Hist., 45, 1980, nr 3, s. 18; E. Rymar, Próba identyfikacji, s. 205.

19 Rękopis kroniki pelplińskiej przechowywany jest w Bibliotece Archiwum Diecezjalnego w Pelplinie, sygn. 421 (622), s. 21: „Vix in menses octo hac dignitate potitus insidiis Marchionum Brandenburg. interemtus est”. Za jej autora uważa się obecnie pochodzącego z Barlinka Georga Klettnera.

${ }^{20}$ Die ältere Deutschen Berichte über Tod der Lucartis, w: SRP, t. 1, s. 771 n.

${ }^{21}$ Oskarżenie Przemysła o spowodowanie śmierci żony nie mogło też przez Pelplin przejść z Gdańska do Meklemburgii. Za taką drogą opowiadał się G. Labuda, rec.: J. Wenta, Zaginiony rocznik oliwski z XIII/XIV wieku, „Zapiski Historyczne” 1980, 45, 3, St. Źródł., 1983, 27, s. 229. 
w tym względzie stosunki gdańsko-lubeckie, skoro informacja o zamordowaniu Lutgardy znalazła się w najszerszej i jednocześnie najmłodszej, bo pochodzącej z końca XIV w., wersji kroniki franciszkanina Detmara z Lubeki22. Trudno też dokładnie prześledzić drogę recepcji informacji o śmierci Przemysła II i towarzyszącego jej wątku uduszenia Lutgardy, którą zawiera Kontynuacja Kroniki halicko-wołyńskiej z rękopisu Bundura/Jarockiego ${ }^{23}$. Musiała stać za tym znajomość na Rusi zapisek ze źródeł powstałych nie tylko w kręgu małopolskim, ale także pochodzących z Wielkopolski i Pomorza Gdańskiego ${ }^{24}$. Problem ten wydaje się być godny osobnego rozpatrzenia, ale dla niniejszego wywodu nie stanowi sprawy pierwszorzędnej. Za taką uchodzić musi jednak próba identyfikacji pochodzenia zabójcy Przemysła II. Założenie, że musiał być on Pomorzaninem nie wydaje konieczne ${ }^{25}$.

Treść rozdziału IV (s. 146-154) już przybliżyłem, nawiązując do postaci Jakuba Kaszuby. Autor w barwny i przez to atrakcyjny sposób starał się opisać przebieg zamachu. Doszedł do wniosku, że oddział specjalny margrabiów brandenburskich, w skład którego wchodziły osoby mówiące po słowiańsku i przebrane za ludzi polskiego króla pod dowództwem Jakuba Kaszuby, zastał Przemysła II i jego ludzi śpiących po uczcie zakrapianej alkoholem. Doszło do próby porwania króla, krótkiej walki, podczas której został on ciężko ranny. Autor, podobnie jak Karol Górski, Bronisław Nowacki i Aleksander Swieżawski ${ }^{26}$, dopuszczał przy tym możliwość śmierci króla na skutek dobicia po nieudanym porwaniu, podczas powrotu oddziału specjalnego z Rogoźna (s. 150). J. Bieniak różni się od swych naukowych poprzedników tylko stosunkiem do lokalnej tradycji, według której Przemysł II zmarł w oddalonych od Rogoźna o ok. 6,5 km Siernikach. Niespodziewanie przeprowadzony atak przez osoby przebrane za ludzi króla miał być jedną z przyczyn szerzącej się później plotki o udziale „swoich” w dokonanym morderstwie. Na owych „swoich” miało wskazywać naprędce przeprowadzone śledztwo w sprawie zabójstwa (s. 150). Choć nie powinno być wątpliwości, że wraz z Przemysłem II przebywali w Rogoźnie zarówno Zarębowie, jak i Nałęcze (s. 36 n., 152), to jednak po raz kolejny zostali oni oczyszczeni przez Autora pracy z zarzutu tak dokonania zamachu, jak i współudziału w nim (s. 152 n.).

Jak więc doszło do oskarżenia Zarębów i Nałęczy (s. 155-180)? Linię obrony przeciwko temu oskarżeniu wyznaczył już Władysław Karasiewicz ${ }^{27}$. Zarębowie i Nałęcze mieli zostać oskarżeni o zdradę w XIV w. przez niechętne im elity małopolskie, aktywne szczególnie w dobie konfederacji Maćka Borkowica. Autor recenzowanej pracy obronę tę w znaczny sposób rozbudował (s. 156). Niechęć do Zarębów i Nałęczy musiała rosnąć ze względu na wysoką pozycję społeczną i urzędniczą przedstawicieli tych rodów. Nie podważyły jej w istotny sposób zmiany na tronach książęcym czy królewskim w Polsce. Szczególną zawiść miały budzić urzędy wojewodów z Wielkopolski dzierżone w pewnym okresie rządów Władysława Łokietka przez połączonych powinowactwem Marcina Sędziwojewica i Wincentego z Szamotuł (s. 164). Ich wrogowie, pamiętając o obecności przedstawicieli tych rodów w Rogoźnie, mogli więc, wedle Autora, rzucić oskarżenie związane z udziałem w zbrodni rogozińskiej. Potwarz ta została podchwycona najpierw przez Rocznik świętokrzyski, w którym wskazano na udział Zarębów i Nałęczy w zbrodni, a potem znalazła się też w innych źródłach. Apogeum niechęci wobec obu rodów nastąpiło więc w czasach Wincentego z Szamotuł (s. 179). Podsycał ją konflikt między małopolskimi doradcami Kazimierza Wielkiego i wojewodą poznańskim Wincentym z Szamotuł czy jego synem Sędziwojem z Czarnkowa (s. 166-168). Pewną rolę odegrał też układ zawarty przez Wincentego z Szamotuł z margrabią brandenburskim (w 1329 albo 1331 r.) i nie zawsze dobrze oceniany sposób prowadzenia przez wojewodę obrony w wojnie z Krzyżakami. Świadectwem tej niechęci była otoczka towarzysząca tajemniczej śmierci Wincentego, przebitego strzałą (s. 176 n.). Któż jednak stał za kreowaniem atmosfery niechęci wobec Zarębów i Nałęczy, i fałszywie ich oskarżał o zdradę, a nawet o morderstwo na Przemyśle II, Autor nie podjął się wskazać.

Zakończenie pracy stanowi Podsumowanie (s. 181-212), w którym Autor w syntetyczny sposób zebrał wygłoszone przez siebie tezy. Dopełnieniem książki są indeks osób i tablice genealogiczne.

Praca J. Bieniaka jest cennym wkładem w rozwój wiedzy dotyczącej dwóch szczególnie ważnych rodów możnowładczych Wielkopolski i zamachu na Przemysła II. Autor należy do niekwestionowanych znawców tematyki genealogiczno-prozopograficznej. Praca napisana jest w sposób, który zainteresuje nie tylko zawodowych historyków, ale też o wiele szersze grono pasjonatów historii. Z pewnością jednak wzbudzi też kontrowersje wśród badaczy, z którymi Autor starł się w dyskusji na łamach swej pracy. Jedyną rzeczą, która w niej razi, jest błędny sposób tworzenia opisów bibliograficznych w przypisach. Łączy on skrótowy zapis cytowanej pracy z określeniem „dz. cyt.”, co jest właściwie niepraktykowane w pracach humanistycznych i utrudnia właściwe zrozumienie treści przypisu.

Marek Smoliński

Uniwersytet Gdański

\footnotetext{
${ }^{22}$ Detmar-Chronik von 1101-1395 mit der Fortsetzung zu 1395-1400 (zunächst bis 1386), wyd. H. Koppmann, w: Die Chroniken der niedersächsischen Städte. Lübeck, t. 1, Lepizig 1884, s. 355.

${ }^{23}$ Kontynuacja Kroniki halicko-wotyńskiej, s. 269.

${ }^{24}$ Przekaz ten połączył bowiem zarzut morderstwa dokonanego na Przemyśle II przez jego bojarów: Zarębów i Nałęczy z opowieścią o wcześniejszym uduszeniu Lutgardy.

${ }^{25}$ Autor przygotowuje na ten temat osobną rozprawę.

${ }^{26}$ Zob. K. Górski, Śmierć Przemysła II, s. 6; B. Nowacki, Przemyst II, s. 216; A. Swieżawski, Przemyst król Polski, Warszawa 2006 , s. 188 n.

27 W. Karasiewicz, Działalność polityczna, s. 15.
} 


\section{Lukasz Ćwikła, Ród Prusów w Lęczyckiem, Sieradzkiem i Sandomierskiem do XVI wieku. Rozsiedlenie - majątki - kariery, Bibliotheca Thomasoviensis, t. 5, Wydawnictwo Uniwersytetu Lódzkiego, Lódź 2019, ss. 250, il.}

Książka Łukasza Ćwikły, związanego zawodowo z Instytutem Historii Uniwersytetu Łódzkiego, jest już drugą opublikowaną w ostatnim czasie pracą o heraldycznym rodzie rycerskim/szlacheckim Prusów na ziemiach polskich w średniowieczu i wczesnym okresie nowożytnym. Rok wcześniej ukazała się bowiem monografia Piotra Szczurowskiego o Prusach mazowieckich $^{1}$. Obie publikacje mają w zamierzeniu zastąpić w odniesieniu do terytoriów, którym są poświęcone, całościową monografię tego clenodium autorstwa Jadwigi Chwalibińskiej, liczącą już przeszło siedemdziesiąt lat².

Monografię Ł. Ćwikły otwiera Wstęp (s. 11-18), w którym został przedstawiony stan badań nad rodem Prusów, zakreślono chronologiczny i terytorialny przedmiot badań, omówiono najważniejsze źródła, streszczono również poszczególne elementy składowe książki. Główna część pracy została podzielona na sześć rozdziałów - pierwszy dotyczy pochodzenia heraldycznego rodu Prusów (s. 19-29), drugi - herbu i zawołań tego clenodium (s. 31-63), trzeci - rozsiedlenia i majątków szlachty herbu Prus w Łęczyckiem, Sieradzkiem i Sandomierskiem (s. 65-112), czwarty - udziału łęczyckich i sieradzkich Prusów w życiu politycznym, gospodarczym i kościelnym Polski (s. 113-140), piąty - zróżnicowania społecznego szlachty herbu Prus w Polsce centralnej (s. 141-154) i szósty - życia rodzinnego i sąsiedzkiego Prusów z tego obszaru (s. 155-169). Ł. Ćwikła podsumowuje swoje ustalenia w zakończeniu (s. 171-177), które otwiera krótki ekskurs: Ekspansja przedstawicieli rodu Prusów na wschód w XV-XVII w. (s. 171-174), wieńczy zaś Podsumowanie (s. 174-177). Recenzowana praca zaopatrzona jest również w wykaz skrótów, bibliografię źródeł i literatury przedmiotu, spis map, tabel i rycin oraz spis aneksów (to wszystko na s. 179-207). Trzy aneksy to tablice genealogiczne poszczególnych rodzin należących do rodu Prusów w Łęczyckiem i Sieradzkiem (s. 207-218), czarno-biała ikonografia różnych odmian herbu Prus (s. 219-235) oraz cztery monochromatyczne zdjęcia przedstawiające fundacje Wspinków z Będkowa: dwóch kościołów (w Będkowie i Skotnikach), dworu w Będkowie oraz obrazu NMP Będkowskiej (s. 237-239). Monografię zamykają: krótkie angielskie streszczenie (s. 241 n.) oraz niezbędny w tego rodzaju pracach indeks osobowy (s. 243-250). Należy podkreślić, że ustalenia Autora zostały udokumentowane wieloma mapami, prezentującymi położenie własności ziemskiej Prusów w Łęczyckiem i Sieradzkiem oraz powiecie opoczyńskim województwa sandomierskiego.

Skrótową ocenę poszczególnych części monografii pióra Ł. Ćwikły wypada zacząć od przybliżenia jej założeń. Autor we wstępie pisze wprawdzie, że jego książka „wpisuje się w nurt badań zorientowanych na genealogię i szeroko rozumianą pozycję szlachty” (s. 11), zastrzega jednak, „że nie jest to typowa praca genealogiczna, tj. nie prezentuje biogramów kolejnych przedstawicieli poszczególnych rodzin, a rysuje nam panoramę szeroko zakrojonej działalności kolejnych gałęzi rodu w układzie problemowym" (tamże). Ów układ problemowy odzwierciedla struktura zasadniczych rozdziałów, co poddam ocenie nieco niżej. Zakres terytorialny swoich dociekań Autor precyzuje jako „Polskę Centralną”, rozumiejąc pod tym pojęciem obszar późnośredniowiecznych i nowożytnych województw łęczyckiego i sieradzkiego oraz powiat opoczyński w województwie sandomierskim (s. 11 n.). Wydaje się jednak, że mamy tu do czynienia z fikcyjnym pojęciem z zakresu geografii historycznej, stworzonym przez Ł. Ćwikłę w celu wykorzystania jego ustaleń dotyczących majątków badanej przezeń terytorialnej gałęzi rodu Prusów. Jednak poza Wspinkami z Będkowa i kilkoma innymi mniej znaczącymi rodzinami herbu Prus (m.in. Zacharskimi, Rudnickimi), których główne posiadłości znajdowały się na obszarze województw łęczyckiego i sieradzkiego, a część dóbr w powiecie opoczyńskim, Autor zajął się (i to wyłącznie w kilku zdaniach) dziedzicami Siodłkowa/Siodłkowic i Bielejowic z Opoczyńskiego (s. 109 n.). Prezentowana monografia dotyczy zatem w rzeczywistości prawie wyłącznie rodzin herbu Prus, które zamieszkiwały Łęczyckie i Sieradzkie (czyli Prusów łęczyckich i sieradzkich), spośród których tylko niektóre familie miały posiadłości w Sandomierskiem. Wniosek ten implikuje kolejny - tytuł książki, po pominięciu niepotrzebnych (a marginalnych) nawiązań do posiadaczy Siodłkowa/Siodłkowic i Bielejowic, powinien brzmieć: Ród Prusów w Łęczyckiem i Sieradzkiem do XVI w., ponieważ jego obecna forma (z włączonym Sandomierskiem) niesłusznie sugeruje, że znajdą się tam rozważania dotyczącego rodzin szlacheckich herbu Prus z obszaru całego rozległego województwa sandomierskiego. Lektura pracy wskazuje jeszcze i na to, że lepiej chyba byłoby poprzestać na cezurze końcowej zamykającej się na początkach XVI w., aniżeli przesuwać ją na połowę tego stulecia (s. 13). Fragmenty opisujące poszczególne aspekty aktywności familii wychodzące poza ścisły początek XVI stulecia zdają się bowiem recenzentowi znacznie słabiej udokumentowane źródłowo od części dotyczących XV w. (przykładowo s. 95-98). Po co wchodzić w głąb XVI stulecia, nie korzystając w całości z bogatych informacji źródłowych oferowanych przez obfity zasób nowożytnych ksiąg ziemskich i grodzkich z obszaru Łęczyckiego i Sieradzkiego? Rozumiem oczywiście Autora, który po przeprowadzeniu pieczołowitej kwerendy w źródłach średniowiecznych skonstatował, że niemal do schyłku XV w. rodziny łęczyckich i sieradzkich Prusów nie wychodziły poza szlachecką przeciętność. Tymczasem pragnął ukazać czytelnikowi awans niektórych spośród nich, mierzony dzierżeniem wyższych urzędów ziemskich przez ich przedstawicieli, do czego doszło wszakże w szerszym zakresie dopiero w pierwszej połowie XVI w. (s. 13).

Istotny z punktu widzenia przedmiotu badań jest rozdział pierwszy monografii, dotyczący pochodzenia heraldycznego rodu Prusów. Z narracji Autora dowiadujemy się, że ten jeden z dwóch jak dotąd zidentyfikowanych polskich rodów rycerskich

${ }^{1}$ P. Szczurowski, Ród heraldyczny Prus na Mazowszu w XIII-XVI wieku, Sandomierz 2018.

2 J. Chwalibińska, Ród Prusów w wiekach średnich, Toruń 1948. 
(obok Dragów-Sasów) niepowstałych na podłożu genealogicznym, ale na bazie pochodzenia rodowców z jednego terytorium, wywodził się z Prus i uformował się z wychodźców pochodzenia bałtyjskiego, migrujących do Polski w wyniku stopniowego podboju tego kraju przez zakon krzyżacki. Konstatacja ta nie jest jednak żadnym novum. Znamy ją także z dzieł nowożytnych heraldyków czy z pracy J. Chwalibińskiej lub znacznie nowszych ustaleń P. Szczurowskiego. Niestety, zasób źródłowy dotyczący rodowców herbu Prus z Łęczyckiego i Sieradzkiego, potwierdzający ich aktywności na tych terytoriach dopiero od końca XIV w., nie pozwolił Autorowi na ustalenie, kiedy ich protoplaści tam przybyli ani też z której części Prus mogli się wywodzić.

W rozdziale drugim Ł. Ćwikła pieczołowicie przeanalizował problematykę związaną z desygnatami clenodium Prusów: herbem, zawołaniem i nazwami rodowymi. Fragment ten należy uznać za bardzo potrzebny w kontekście niezwykle zróżnicowanego rozwoju heraldyki i innych desygnatów Prusów na przestrzeni średniowiecza. Nadto wypada wskazać, że osobne rozdziały o tej tematyce występowały już we wcześniejszych monografiach rodowych ${ }^{3}$. Wyodrębnienie tej problematyki wydaje się tym bardziej potrzebne, że Prusowie byli rodem, który uformował się w inny sposób niż ogromna większość polskich rodów rycerskich/szlacheckich. Brak powiązań genealogicznych pomiędzy gałęziami terytorialnymi, a może nawet i wewnątrz nich, przedłużał w czasie proces standaryzacji desygnatów rodowych, a w zakresie heraldyki nigdy nie został doprowadzony do końca. Zgodnie z ustaleniami Ł. Ćwikły do początków epoki nowożytnej ukształtowały się trzy najpowszechniejsze typy herbu Prusów: tzw. Prus I (Połutorakrzyża), Prus II (Wilczekosy) oraz Prus III (stanowiący hybrydę godła Wilczekosy z Podkową i zaćwieczonym na niej Połutorakrzyżem). Znacznej różnorodności herbów towarzyszyła również wielość proklam, które odnotował Autor (herb Prus I: pięć, herb Prus II: także pięć, herb Prus III: dwie). Analiza i wnioski zaprezentowane w tym rozdziale są oparte na wyczerpującym materiale pochodzącym ze źródeł pisanych i ikonografii (tu wyzyskano wydatnie jeden z aneksów). Wydaje się wszakże, że warto byłoby mocniej podkreślić fakt, iż długi okres standaryzowania herbów, wielość wizerunków herbowych i zawołań u Prusów stanowi wyraźną analogię do rozwoju desygnatów innego polskiego rodu rycerskiego/szlacheckiego, także uformowanego na podłożu wspólnego pochodzenia terytorialnego z obszaru spoza Królestwa Polskiego: Dragów-Sasów z koronnej Rusi ${ }^{4}$.

W kolejnych rozdziałach $(3,4,6)$ Autor przedstawił genealogię oraz działalność na różnych polach zidentyfikowanych przezeń familii herbu Prus osiadłych na terenie województw łęczyckiego i sieradzkiego. Najszersze i osobne fragmenty książki dotyczą: Cygańskich, Głowackich, Gutkowskich/Olszowskich, Gutkowskich/Wilkuckich, Lubiatowskich, Rudnickich, Wspinków z Będkowa i Szamowskich. Tylko jeden podrozdział (s. 103-109) został poświęcony drobiazgowi heraldycznemu herbu Prus, co wydaje się zabiegiem słusznym z punktu widzenia konstrukcji książki. Zgodnie z ustaleniami Autora na terenie województw łęczyckiego i sieradzkiego oraz powiatu opoczyńskiego istniało 28 „gniazd” rodu Prusów, przy czym w 12 spośród nich występowała szlachta herbu Prus I, w 15 posiadacze herbu Prus II, a tylko w jednym familia herbu Prus III (s. 111 n.).

Przedstawiony wykaz najważniejszych elementów składowych prezentowanej monografii pozwala na stwierdzenie, że Autor zadał sobie wiele trudu, aby jego dzieło zawierało elementy oryginalne w stosunku do innych monografii o podobnej tematyce, w których większy nacisk był zazwyczaj położony na problematykę genealogiczną ze szczególnym uwzględnieniem dociekań nad najstarszymi protoplastami rodów i ich poszczególnych gałęzi, działającymi w stuleciach XIII-XIV. Oceniając to założenie z punktu widzenia łatwości docierania do informacji dotyczących różnych aspektów działalności poszczególnych rodowców, zastosowanego przez Ł. Ćwikłę podziału konstrukcyjnego nie można wszakże uznać za najszczęśliwszy. Zostały one w moim odczuciu sztucznie porozbijane pomiędzy poszczególne rozdziały. Znacznie korzystniejszy dla odbioru warstwy materiałowej byłby układ bardziej klasyczny, w którym najpierw przedstawiono by poszczególne rodziny i działalność ich przedstawicieli na wszystkich polach ${ }^{5}$, następnie zaś w rozdziałach podsumowujących Autor przeprowadziłby osobną analizę w kontekście wybranych problemów.

Rzeczywistą próbą syntezy problemu w monografii Ł. Ćwikły wydaje się rozdział piąty, dotyczący zróżnicowania społecznego szlachty herbu Prus. Autor posługuje się w nim metodą ,punktową”, nawiązującą do podejścia zaproponowanego już dawniej w odniesieniu do elity szlacheckiej województwa sieradzkiego przez Alicję Szymczakową . Klasyfikacji poddano wszakże tylko wymienione wyżej rodziny, które zostały omówione szerzej. Na najwyższym miejscu wśród nich znalazła się familia Wspinków z Będkowa, ale tylko ze względu na znaczne uposażenie majątkowe (w tym posiadanie miasta lokacyjnego, jakkolwiek niewielkiego) i stosunkowo sporą liczbę duchownych wśród jej przedstawicieli, co dawało także dodatkowe punkty za wykształcenie. Dla recenzenta ważne są ustalenia Autora podkreślające bardzo niewielką liczbę urzędników ziemskich wśród łęczycko-sieradzkich Prusów. Istotne wydaje się również to, że Prusowie z tego obszaru w szeregi szlachty urzędniczej zaczęli wchodzić dopiero w samej końcówce XV w. Były to także urzędy stosunkowo niskiej rangi (łowczostwa, wojstwa), a kasztelania (i to konarska łęczycka, czyli jedna z najniższych, tzw. drążkowych) zdarzyła się przed końcem średniowiecza tylko jedna. Dodajmy, że niewiele lepiej było na początku nowożytności (wojstwa, chorąstwa, nadto kasztelania brzezińska).

\footnotetext{
${ }^{3}$ Zob. np. J. Pakulski, Ród Godziębów w średniowiecznej Polsce. Studium genealogiczne, Torun 2005, s. 20 -39.

${ }^{4}$ L. Wyrostek, Ród Dragów-Sasów na Węgrzech i Rusi Halickiej, Kraków 1932 (nadb. z: „Rocznik Polskiego Towarzystwa Heraldycznego”, t. 11), s. 122-129; J. Wroniszewski, Kryteria herbowe w badaniach genealogicznych, w: Genealogia. Problemy metodyczne w badaniach nad polskim społeczeństwem średniowiecznym na tle porównawczym, red. J. Hertel, Toruń 1982, s. $120 \mathrm{n}$.

5 Zob. np. A. Szymczakowa, „Nobiles Siradienses”. Rody Porajów, Pomianów, Gryfów, Kopaczów i Pobogów, Warszawa 2011; J. Wroniszewski, „Nobiles Sandomirienses”. Rody Dębnów, Janinów, Grzymałów, Doliwów i Powatów, Kraków 2013.

${ }^{6}$ A. Szymczakowa, Szlachta sieradzka w XV wieku. Magnifici et generosi, Łódź 1998, s. 15-28.
} 
Za symptomatyczne należy również uznać, że najmajętniejsza spośród łęczycko-sieradzkich familii herbu Prus, Wspinkowie, nie posiadała w XV w. w swym gronie żadnego urzędnika ziemskiego. Pierwsi dostojnicy wśród nich pojawili się dopiero na początku XVI w. Za pewien niedostatek rozważań Autora o pozycji poszczególnych przedstawicieli interesującej go grupy społecznej wypada uznać niewykorzystanie jako kryterium kwantytatywnego wymiaru ich aktywności w charakterze asesorów sądów ziemskich i grodzkich oraz arbitrów w postępowaniach pojednawczych, choć informacje na ten temat można znaleźć w rozdziałach prezentujących ich działalność.

W omawianym rozdziale Autor deklaruje również „prześledzenie dróg awansu” (s. 146) Prusów z poddanego obserwacji obszaru, wydaje się jednak, że brakuje tu wskazania wprost na pewne istotne strategie widoczne w przypadku kilku rodzin. Warto byłoby podkreślić wyraźniej rolę koligacji z wybitniejszymi rodzinami, tak jak było w przypadku Głowackich skoligaconych z Lubrańskimi. Nawiązania do tego znajdujemy jednak tylko poza omawianym rozdziałem (s. 131, 136). W przypadku Szamowskich widać natomiast klientelizm wobec wybitnych możnych, którzy mogli ułatwiać awans ich przedstawicielom (zob. powiązania Jana Szamowskiego jako urzędnika zarządu starościńskiego z wybitnymi możnowładcami końca XV i początków XVI w., ukazane przez Ł. Ćwikłę i w dalszej części niniejszej recenzji).

Za nieuzasadnione uważam umieszczenie w zakończeniu podrozdziału o migracji łęczycko-sieradzkich Prusów na Wschód w XV-XVII w. Sądzę, że problem ten nie został przez Autora gruntownie przebadany, a przedstawiając go, opiera się on prawie wyłącznie na literaturze przedmiotu i bardzo niewielkiej liczbie źródeł (przede wszystkim drukowanych regestach Metryki Koronnej). Fragment ten można było całkowicie pominąć, a w zamian rozbudować Podsumowanie, które składa się z dwóch stron tekstu (obok wykresu i mapy) i wydaje się w związku z tym nazbyt lakoniczne.

Zakres wykorzystanych przez Ł. Ćwikłę źródeł archiwalnych i opublikowanych zasługuje oczywiście na uznanie. Zdaje się wszakże, że skoncentrował się on przede wszystkim na analizie archiwaliów (głównie ksiąg ziemskich i grodzkich) z obszaru ziem łęczyckiej i sieradzkiej, co jest przyjęte w pracach genealogiczno-prozopograficznych ograniczonych do jednego lub kilku terytoriów. Recenzent nie uważa tego za rażącą niedoskonałość, już dawno jednak zwrócono uwagę na znaczącą mobilność późnośredniowiecznej i wczesnonowożytnej szlachty polskiej. Uważam zatem, że Autor mógłby poszerzyć kwerendę o podstawowe dla jego badań zespoły źródeł archiwalnych z ziem sąsiadujących z województwami łęczyckim i sieradzkim od zachodu i północy. Chodzi tu przede wszystkim o przechowywane w Archiwum Państwowym w Poznaniu księgi ziemskie i grodzkie powiatów województwa kaliskiego przylegających do wspomnianych województw środkowej Polski: konińskiego, a zwłaszcza kaliskiego (warto przy tym zauważyć, że całość ksiąg ziemskich kaliskich z okresu średniowiecza została kilka lat temu udostępniona w sieci, co niepomiernie ułatwia prowadzenie w nich poszukiwań). Kolejnymi źródłami sądowymi, w których można spodziewać się znalezisk dotyczących problematyki analizowanej w recenzowanej monografii, są księgi ziemskie i grodzkie Kujaw Brzeskich (brzeskie, kowalskie i przedeckie), przechowywane w AGAD. Zapewne wyniki nie dałyby takiej obfitości danych źródłowych jak w przypadku ksiąg ziemskich i grodzkich z obszarów województw łęczyckiego i sieradzkiego, jednak na pewno mogłyby uzupełnić dane prozopograficzne i genealogiczne (a może i odnoszące się do spraw majątkowych) poszczególnych interesujących Autora rodzin herbu Prus. Podam tylko jednostkowy przykład, dotyczący jednak przedstawiciela rodu Prusów, którego jako posiadacza kasztelanii konarskiej łęczyckiej (1485-1532, zm. po 1516, po uprzednim, w 1513 r., scedowaniu urzędu na rzecz syna za zgodą króla) należy uznać za najwybitniejszą osobistość tego clenodium w Sieradzkiem i Łęczyckiem na przełomie epoki średniowiecznej i nowożytnej. Chodzi oczywiście o Jana Szamowskiego, którego karierę rozpoczęło związanie się z zarządem starościńskim starostwa łęczyckiego, kiedy z ramienia starosty Piotra Donina z Prawkowic i Ujazdu został w 1481 r. burgrabią łęczyckim. Informacje o tym znajdujemy w prezentowanej pracy (s. 117 n.), jednak Autor zapominał dodać, że po śmierci Piotra Donina w 1484 r. Szamowski związał się z kolejnym starostą łęczyckim, Rafałem z Leszna, z którego ramienia pełnił urząd burgrabiego łęczyckiego aż do początków 1496 r. ${ }^{7}$ Od pewnego czasu jest wszakże wiadomo, że Rafał w 1494 r. został starostą brzeskim na Kujawach i jako taki zarządzał również starostwami kowalskim i radziejowskim (na tym ostatnim otrzymał także zapis od króla Jana Olbrachta) i pozostał na urzędzie starosty brzeskiego do śmierci w 1501 r. ${ }^{8}$ Dociekliwy badacz powinien podejrzewać, że klient możnowładcy, a stosunek klientalny pomiędzy Leszczyńskim a Janem Szamowskim na pewno zachodził, sprawujący z jego ramienia urząd burgrabiowski, mógł podążyć za swoim patronem do nowych starostw, i zweryfikować tę hipotezę w stosownych źródłach. Dokonał tego jednak dopiero recenzent i to z wynikiem pozytywnym. Jan Szamowski jako burgrabia brzeski Rafała Leszczyńskiego występował od 1494 r. ${ }^{9}$ W 1495 r. awansował jednak na urząd wicestarosty (podstarościego) i w tym charakterze wyręczał zajętego robieniem kariery przy dworze królewskim Rafała aż do jego śmierci w $1501 \mathrm{r} .{ }^{10}$ Pełnienie przez Jana funkcji burgrabiego, a potem wicestarosty brzeskiego potwierdza dla lat 1494-1501 także najstarsza z zachowanych ksiąg ziemskich kowalskich ${ }^{11}$. Zarządzanie w imieniu Rafała Leszczyńskiego jego kujawskimi starostwami miało jeszcze jedną konsekwencję dla Szamowskiego - jako urzędnik starosty bywał powoływany na tym obszarze do postępowań polubownych. Źródła potwierdzają, że uczestniczył w sześciu jednaniach

\footnotetext{
${ }^{7}$ Daty sprawowania starostwa łęczyckiego przez Leszczyńskiego zob. UdR. Spisy, t. 2/1, s. 88.

${ }^{8}$ UdR. Spisy, t. 6/1, s. 215, 222, 229.

${ }^{9}$ AGAD, Księgi grodzkie brzeskie, ks. 8, k. 224, 225v, 245

${ }^{10}$ Tamże, ks. 8, k. 252, 253, 254v, 260, 266v, 272v, 273v, 277, 281, 285, 292v, 298, 280, 310, 314, 315v, 324, 325v, 331, 340, 345v, 348, 351, 353v, 354, 357, 373v, 376v, 379, 390v, 397v, 411v, 412, 415; ks. 9, k. 7v, 22, 26av, 40, 50, 50v, 54v, 57v, 65, 75, 76, 79v, 85, 98v, 99v, 103.

${ }^{11}$ AGAD, Księgi grodzkie kowalskie, ks. 1, k. 362, 364, 365, 367, 368v, 370, 373, 374, 376 (tu w 1497 r. Szamowski został nawet określony jako wicestarosta brzeski i kowalski), 380, 383, 403, 405, 407, 413
} 
w Brześciu Kujawskim ${ }^{12}$ i w jednym w Kowalu ${ }^{13}$. Dodajmy jeszcze, o czym rzetelnie poinformował nas Ł. Ćwikła (s. 119), że funkcję wicestarosty Jan pełnił w imieniu Leszczyńskiego także w 1500 r. w Sieradzu. Warto przy tym zastanowić się jeszcze, czy nie był również zaangażowany w zarząd starostwa piotrkowskiego, które także znajdowało się w tym czasie w rękach jego patrona $^{14}$. Reasumując, dane dotyczące Szamowskiego podane przez Autora wraz z informacjami uzupełniającymi pokazują, że była to osoba o niezwykłej mobilności, zaangażowana w zarząd kilku starostw środkowopolskich jednocześnie.

Trzeba także zgłosić drobne uwagi krytyczne dotyczące wykorzystania literatury przedmiotu. Wśród monografii cytowanych przez Ł. Ćwikłę brakuje książki Michała Słomskiego o urzędnikach i personelu arcybiskupiego zamku w Łowiczu. Tymczasem znaleźć tam można nieznane Autorowi informacje uzupełniające życiorys występującego na kartach jego książki Wojciecha Gutkowskiego, który był sędzią łowickim arcybiskupów gnieźnieńskich ${ }^{15}$. Dodajmy jeszcze, że Autor nie musiał we fragmencie swego dzieła dotyczącym Anny, wdowy po Janie Wspinku z Będkowa, powoływać się na informację uzyskaną od Tadeusza Nowaka (s. 92 i przyp. 185), gdyż stosowne dane o jej późniejszych małżeństwach (drugim z kasztelanem brzezińskim Mikołajem Oporowskim z Miłonic i trzecim z kasztelanem łęczyckim Tomaszem z Soboty) znajdują się w monografii Tomasza Pietrasa o Oporowskich herbu Sulima ${ }^{16}$

Wydaje mi się także, że Autor mógł w większym zakresie wyzyskać swoje wnioski dotyczące osadnictwa Prusów. Zgodnie z nimi koncentrowało się ono nad rzeką Wolborką, stanowiącą granicę pomiędzy Łęczyckiem a Sieradzkiem (s. 65 n.). Nie można wykluczyć, że to ustalenie mogło posłużyć do wysunięcia hipotez dotyczących najdawniejszej obecności przedstawicieli późniejszego rodu Prusów na obu tych obszarach. Osadnictwo tego clenodium na obu brzegach wspomnianej rzeki sugerowałoby, że ich najstarsi przedstawiciele znaleźli się w środkowej Polsce jeszcze przed wydzieleniem ziemi sieradzkiej przez księcia kujawsko-łęczycko-sieradzko-dobrzyńskiego Kazimierza Konradowica swemu najstarszemu synowi Leszkowi Czarnemu w 1261 r. Może to właśnie z okresem panowania księcia Kazimierza należy wiązać początki migracji zachodniobałtyjskich nobilów z Prus do środkowej Polski, zwłaszcza że Piast ów dowodnie uczestniczył w rywalizacji o ziemie zachodnich Bałtów ${ }^{17}$ i prawdopodobnie pozyskiwał na terenie Prus zwolenników dla swojej polityki, co skutkowało następstwami w postaci poszukiwania przez nich schronienia na terytoriach znajdujących się pod jego rządami. Nie można również wykluczyć, że osadnictwo pruskich nobilów na terenie ziemi sieradzkiej mogło mieć po $1261 \mathrm{r}$. związek z polityką jaćwieską Leszka Czarnego. Wysunięte tu hipotezy wydają się korespondować z tezą J. Chwalibińskiej przyjętą przez Ł. Ćwikłę, że Prusowie łęczycko-sieradzcy „nie czuli żadnego związku z grupą mazowiecką” tego clenodium (s. 63).

W recenzowanej pracy znajdujemy również pewne niespotykane dotąd w monografiach naukowych wyrażenia, jak np. przymiotnik „,prawomocny” (s. 21, 27), który ma, jak zdaje się recenzentowi, zastąpić określenie „,najpewniejszy”/,najbardziej prawdopodobny” przy szeregowaniu hipotez naukowych. Neologizmy tego rodzaju (podobnie jak „wróżda interklenodialna”, s. 63) rażą jednak w pracy naukowej. Autorowi zdarza się również używać stwierdzeń niezrozumiałych z genealogicznego punktu widzenia (s. 23: „Pruscy nobilowie należeli do określonych rodów agnatycznych, powstałych w wyniku działalności łupieskiej ich członków").

Monografia o przedstawicielach rodu Prusów w Łęczyckiem i Sieradzkiem w późnym średniowieczu i na początku epoki nowożytnej stanowi bez wątpienia istotne uzupełnienie badań nad późnośredniowieczną szlachtą polską. Oparta na rzetelnej kwerendzie w źródłach archiwalnych, przedstawia nieznane dotąd aspekty dotyczące genealogii, prozopografii i życia społecznego kilku familii szlacheckich aktywnych na wspomnianym wyżej obszarze. Ł. Ćwikła zaprezentował nam na pewno obraz znacznie pełniejszy od tego, który znajduje się w pracy J. Chwalibińskiej. Natomiast jego przekonanie, że obalił on tezę swojej poprzedniczki o nieodgrywaniu przez ród Prusów „specjalnej” roli w Polsce (s. 140) należy uznać za zdecydowanie przesadzone i nieznajdujące potwierdzenia w wynikach, które uzyskał. Przeciwnie, wykazanie przez Autora, że Prusowie z Łęczyckiego i Sieradzkiego dopiero w końcu XV stulecia zaczęli uzyskiwać pierwsze nominacje na urzędy ziemskie zdają się raczej tezę J. Chwalibińskiej dodatkowo potwierdzać, aniżeli jej zaprzeczać.

Sobiestaw Szybkowski Instytut Historii Uniwersytet Gdański

${ }^{12}$ AGAD, Księgi ziemskie brzeskie, ks. 8, k. 280, 280v (1495, superarbiter w sporze Stanisława i Bogusza z Obałek z Piotrem z Mikołajczewic i jego dziećmi), 345v (1496, jeden z arbitrów w sporze dziedziców Woli i Mąkoszyna), 379 (1497, jeden z arbitrów w sporze podstolego brzeskiego Szymona z Kościoła (Kościelnej Wsi) i Jana Moszczeńskiego z Kościoła), 397v, 398 (1497, jeden z arbitrów w sporze wspomnianego Szymona z Kościoła i Łukasza z Zakrzewa), ks. 9, k. 22 (1499), 85v (jeden z arbitrów w sporze Piotra Moszczeńskiego z Kościoła z jego siostrami stryjecznymi, córkami zmarłego Jana Moszczeńskiego).

13 AGAD, Księgi grodzkie kowalskie, ks. 1, k. 372 (1495, jeden z arbitrów w sporze Jana z Janowic i Wojciecha z Sompolna).

14 Tamże, k. 378.

15 M. Słomski, Urzędnicy i personel zamku arcybiskupów gnieźnieńskich w Łowiczu (XIV w. - 1531 r.), Warszawa 2017, s. 160, 234 (tutaj wszakże Wojciech Gutkowski został przypisany do Gutkowa w powiecie raciąskim i herbów Rawa lub Luba). W tej pracy znajdują się również odniesienia do innego łęczycko-sieradzkiego Prusa, Stanisława Szamowskiego (tamże, s. 97, 162, 217, 232, 236 n.), jednak podane tam informacje pokrywają się z tymi, które figurują w książce $Ł$. Ćwikły.

16 T. Pietras, Oporowscy herbu Sulima. Kariera rodziny możnowładczej w późnośredniowiecznej Polsce, Łódź 2013 , s. 138 (w przyp. 413 zawarta również sugestia, że Jan Wspinek zmarł w 1453 lub 1454 r.).

17 Zob. np. J. Powierski, Kazimierz Konradowic a początki rywalizacji o ziemie zachodniobaltyjskie (do 1247 r.), „Ziemia Kujawska”, 6, 1981, s. 5-45; tenże, Stanowisko polityczne książat polskich wobec ludów battyjskach i zakonu krzyżackiego w okresie najazdów litewskich (1261-1263), „Acta Baltico-Slavica”, 15, 1983, s. 7-52; tenże, Książę kujawski i łęczycki Kazimierz a zakon krzyżacki w latach 1248-1249, „Ziemia Kujawska”, 7, 1984, s. 29-57. 
Marek L. Wójcik, Pieczęcie rycerstwa śląskiego w dobie przedhusyckiej, t. 1-2, Księgarnia Akademicka - Uniwersytet Wrocławski, Kraków-Wrocław 2018, t. 1, ss. 509, fot., il.; t. 2, ss. [5] + 516-1019, fot., il.

W 2019 r. [z datą 2018] ukazał się katalog pieczęci rycerstwa śląskiego opracowany przez Marka Wójcika. Jego Autor jest doświadczonym badaczem, którego zainteresowania naukowe skupiają się na naukach pomocniczych historii: genealogii, dyplomatyce, heraldyce, a od dłuższego czasu także sfragistyce. Na opublikowaną w dwóch tomach, o ciągłej numeracji stron, książkę składa się spis treści (s. 5-14), wstęp (s. 15-39), bibliografia z wykazem skrótów (s. 41-109), katalog pieczęci (s. 111-906), wykaz dysponentów pieczęci, zawierający również sygnatury archiwalne egzemplarzy odcisków, które zostały wykorzystane jako materiał ilustracyjny (s. 907-940), niemieckojęzyczny abstrakt (s. 941-944) oraz indeksy: osobowy i geograficzny (s. 945-1019). Zasadnicza część pracy, czyli katalog, zawiera opisy 933 wzorów pieczęci, należących do przedstawicieli bez mała 430 rodzin zakwalifikowanych przez Autora do grupy śląskiego rycerstwa. Mamy więc do czynienia z edycją pieczęci o skali niespotykanej dotąd w polskich badaniach sfragistycznych.

Pisząc recenzję prac tego typu, już choćby ze względu na ich materiałowy charakter, ale też liczbę publikowanych w nich źródeł, łatwo popaść w manierę wychwytywania i wskazywania potknięć autora albo skupiania się na ogromie wykonanej przez niego kwerendy. Jednak zarówno owe potknięcia czy dyskusyjne rozwiązania przyjęte przez wydawcę, jak i sama rozległość kwerendy oraz wielkość publikowanego materiału nie muszą stanowić o naukowym znaczeniu wydawnictwa. I jedno, i drugie podejście może przy tym prowadzić do pobieżnej jego oceny. W tym miejscu muszę zastrzec, że nie jestem śląskoznawcą, a głównym przedmiotem mojego zainteresowania są pieczęcie. Powoduje to, że wobec ustaleń genealogicznych dokonanych przez M. Wójcika znajduję się w sytuacji dyletanta, świadomego swych braków w zakresie wiedzy specjalistycznej. Dlatego też niżej będę skupiał się na aspektach sfragistycznych wydawnictwa. Chcąc przy tym uniknąć naszkicowanej wyżej sytuacji, rozpocznę od uwag o charakterze bardziej szczegółowym, by później przejść do próby całościowej oceny publikacji.

Merytoryczną cześć książki otwiera wstęp. Został on skonstruowany przez Autora dość konserwatywnie. Omówiono w nim w olbrzymim skrócie (co nie jest zarzutem) historię pieczęci i jej znaczenie źródłowe, scharakteryzowano także - tym razem dość obszernie (co może już budzić pewne wątpliwości w kontekście dalszych uwag) renesans sfragistyki polskiej, wymieniając ważniejsze inicjatywy tak polskie, jak i pozapolskie (choć często z udziałem polskich badaczy) z zakresu sfragistyki. Ale prezentacja stanu polskich badań nad pieczęciami rycerskimi to już tylko jedno zdanie, przypis odsyła zaś do cennej, ale bibliograficznie już niekoniecznie aktualnej pracy Jana Wroniszewskiego, opublikowanej w 2006 r. ${ }^{1}$ Znacznie szerzej omawia Autor stan badań nad sfragistyką śląską w ogóle, a pieczęciami rycerstwa śląskiego w szczególności. Ta dysproporcja jest całkowicie zrozumiała, zważywszy specyfikę sfragistyki śląskiej, w której krzyżowały się wpływy polskie, czeskie i niemieckie. I właśnie z tego względu Autor powinien pokusić się o nieco szersze naszkicowanie modelu czy modeli badań nad pieczęciami rycerskimi zarówno w Czechach, Niemczech, jak i Polsce, które stanowią punkt odniesienia dla jego publikacji. A jeżeli już zdecydował się na ukłon wyłącznie w stronę polskich badaczy, to omówienie stanu badań powinno chyba być nieco bardziej precyzyjne. Znaczną część wstępu zajmuje opis problemów merytorycznych, które napotkał Autor, opracowując koncepcję pracy. Rozważania te pokazują, jak bardzo skomplikowanej materii dotknął. Ze wstępu wynika, że pierwotnie jako cezurę kończącą pracę przyjął rok 1526, ale precyzyjnie wyjaśnione względy merytoryczne skłoniły go do przyjęcia dość elastycznej cezury „czasów przedhusyckich” (s. 22-25). Wydaje się, że z metodologicznego punktu widzenia jest to rozwiązanie słuszniejsze. Rok 1526 (ale właściwie też każdą inną datę roczną) trudno byłoby uznać za istotną cezurę sfragistyczną, choć niewątpliwie może być taką z punktu widzenia historii politycznej. Badanie zbiorów pieczęci należących do grup społecznych to przecież badanie ewolucji, procesów, których nie da się z reguły zamknąć w ramy konkretnych lat.

Pozostawiając na boku, ze względu na brak kompetencji recenzenta, wyjaśnienia Autora co do zaliczenia do grupy rycerstwa poszczególnych dysponentów, ale też zakresu terytorialnego pracy, zatrzymajmy się nad elementami związanymi ze sfragistyką. Dotyczy to uwag Autora na temat publikacji w katalogu pieczęci duchowieństwa o szlacheckim pochodzeniu oraz jego rozważań nad pieczęciami zwanymi przezeń urzędniczymi. W pierwszym przypadku (s. 29 n.) Autor przyjął dość arbitralne kryterium kwalifikacji. Uwzględniał bowiem w zestawieniu pieczęcie tylko tych duchownych, których legenda nie zawierała odniesień do godności kościelnych, a oprócz tego członków zakonów rycerskich. Poza katalogiem pozostały zatem te pieczęcie duchowieństwa rycerskiego pochodzenia, które w ikonografii odwoływały się do motywów religijnych, w legendzie zaś do godności kościelnych, oraz takie, które w ikonografii czerpały co prawda ze schematów ikonograficznych wypracowanych przez rycerstwo, ale w legendzie zawierały odniesienia do godności kościelnych (przykłady ich podaje Autor na s. 30 w przyp. 52). O ile w pierwszym przypadku decyzja Autora wydaje się dyskusyjna, ale do przyjęcia, to zastosowanie takiego rozwiązania dla drugiej grupy pominiętych pieczęci musi dziwić, już choćby z tego względu, że - jak wspomniano - katalog uwzględnia pieczęcie członków zakonów rycerskich, choć przecież w ich legendach także pojawia się określenie frater (zob. np. Katalog ${ }^{2}$, nr 79, s. 170; nr 289, s. 339). Wyłączenie owych z zespołu pieczęci danej rodziny powoduje, że pominięte zostały pewne aspekty samoprezentacji jej ewidentnych przedstawicieli, którzy, mimo że ich kariera potoczyła się nieco inaczej niż

\footnotetext{
${ }^{1}$ J. Wroniszewski, Średniowieczne pieczęcie rycerstwa polskiego, w: Pieczęcie w dawnej Rzeczypospolitej. Stan i perspektywy badań, red. Z. Piech, J. Pakulski, J. Wroniszewski, Warszawa 2006, s. 233-250.

2 Odwołania w niniejszym tekście do Katalogu odnoszą się do niewyróżnionego w omawianej pracy śródtytułem katalogu pieczęci, zajmującego w tomie pierwszym s. 111-509, w tomie drugim s. 515-906.
} 
pozostałych współrodowców, poprzez eksponowanie herbu podkreślali przynależność do wspólnoty krewniaczej. A ilustrują one, ważne z punktu widzenia semiotyki antropologicznej (której znaczenie dla badań sfragistycznych Autor podkreśla: zob. s. 16, 18 i tamże przyp. 10), aspekty przekuwania rodowego, kolektywnego ego w kładzione na pieczęcie imago. Na pieczęciach duchowieństwa interesującego nas typu mamy de facto do czynienia z konstrukcją komunikatu analogiczną do występującej na rycerskich pieczęciach osobistych o urzędniczym charakterze ${ }^{3}$. Do problemu pieczęci urzędniczych Autor nawiązuje w następnym akapicie (s. 30 n.). Wywody jego na ten temat, a właściwie zasadność ich umieszczenia w tym miejscu, budzą jednak pewne wątpliwości. Wydaje się, że nie zauważa on różnicy między pieczęciami urzędniczymi (używanymi przez konkretną, wskazaną w legendzie osobę, z racji sprawowania urzędu, zob. np. Katalog, nr 186, s. 258; nr 187, s. 259; nr 246, s. 305) a urzędowymi (czyli pieczęciami urzędu, używając dzisiejszej terminologii pieczęciami instytucji, przykłady takich pieczęci podaje Autor na s. 30 n., przyp. 56). Te ostatnie nie posiadały z reguły odniesień do konkretnej osoby i często funkcjonowały w ramach czasowych przekraczających czas życia jednostki. Dyskusja na ich temat, prowadząca do zaprezentowanego wyżej podziału, toczyła się w kontekście nowożytnych pieczęci polskich starostów i sądów grodzkich ${ }^{4}$. W jej świetle wyodrębnienie w osobną grupę pieczęci starostów wrocławskich, ząbkowickich czy kamienieckich, działających w imieniu króla czeskiego i do jego autorytetu odwołujących się w ikonografii pieczęci, w legendzie zaś podających tylko nazwę urzędu i - ewentualnie - określających jej rodzaj kancelaryjno-prawny, wydaje się naturalne i niepotrzebujące aż tak szerokiego uzasadnienia.

Podziw czytelnika musi budzić zakres kwerendy, który Autor prezentuje na następnych kartach (s. 31-35). Ze względu na specyfikę regionu konieczne okazało się bowiem przeprowadzenie poszukiwań w instytucjach przechowujących szeroko rozumiane materiały sfragistyczne (oprócz odcisków czy typariuszy także odlewy, fotografie i odrysy, dawne opisy) nie tylko w Polsce, ale też w Czechach, Niemczech czy Austrii. Podkreślić przy tym trzeba, że poszukiwaniami objęte zostały też fora internetowe i zbiory prywatne. Autor nie wspomina co prawda o tym we wstępie, ale na konstatację taką pozwala lektura samego katalogu (zob. np. s. 118, 186, 295, 532, 735). Uwzględnianie w badaniach zbiorów prywatnych, zazwyczaj niechętnie udostępnianych badaczom przez właścicieli, a przede wszystkim pojawiających się w Internecie wzmianek o obiektach sfragistycznych zdaje się wymogiem czasów, w których przyszło nam działać. Tę część rozważań zamyka charakterystyka zasad wydawniczych, do której za chwilę wrócimy.

Lektura stosunkowo krótkiego wstępu (wraz z omówieniem zasad edycji to 24 strony, podczas gdy samo zestawienie bibliografii to łącznie stron 70) pozostawia niedosyt, który pogłębia się po lekturze całego opracowania. Zdaję sobie sprawę, że wstęp do wydawnictwa źródłowego może przybierać różne kształty: od prostego wyjaśnienia zasad opracowania i prezentacji materiału, po szersze studium, zawierające jego analizę. W naszym przypadku Autor odwołał się raczej do pierwszego modelu: po wyjaśnieniu znaczenia pieczęci i charakterystyce działań środowiska badawczego oraz omówieniu stanu badań uzasadnia decyzje związane z kwalifikacją źródeł do publikowanego korpusu, by wreszcie zaprezentować kształt noty katalogowej. Jednak w przypadku edycji, z którą mamy do czynienia, sądzę, że wstęp powinien zostać uzupełniony o prezentację właściwości samego materiału. Przekonanie to wynika z osobliwości śląskiej sfragistyki rycerskiej, kształtującej się na pograniczu kręgów kultury niemieckiej, czeskiej oraz polskiej i będącej ich częścią wspólną. I to właśnie dlatego, że nie jest ona ani całkiem czeska, ani polska, ani niemiecka publikacja powinna zawierać elementy ułatwiające zrozumienie publikowanego zespołu źródeł. Zdaję sobie sprawę, że to, co napisałem wyżej może być efektem błędnego rozumienia specyfiki śląskich pieczęci rycerskich. Ale właśnie dla uniknięcia takich nieporozumień wyjaśnienie owej swoistości wydaje mi się celowe. Warte rozwinięcia i zilustrowania śląskimi przykładami byłyby też niektóre przynajmniej możliwości analizy pieczęci, sygnalizowane przez Autora na początku wstępu, jak choćby rola pieczęci w systemie komunikacji społecznej. Bez komentarza zostawia Autor takie zagadnienia jak pieczętowanie w masie woskowej barwy czerwonej, używanie contrasigillów przez rycerzy (czy pieczętowanie w czerwonym wosku albo dysponowanie pieczęcią służącą jako contrasigillum można uznać za wyznacznik pozycji społecznej dysponenta?), dziedziczenia pieczęci (czy dotyczyło tylko biedniejszych rodzin, czy też było zjawiskiem szerszym, uzasadnionym kulturowo?). To przykłady tylko kilku pytań, które rodzą się po zestawieniu treści wstępu z materiałem publikowanym w katalogu. Sądzę, że warto, by Autor rozważył możliwość opracowania i publikacji osobnego studium, poświęconego śląskiej sfragistyce rycerskiej, zawierającego generalizację wniosków płynących z jego badań. Dopiero ono dawałoby właściwy „klucz” do recenzowanej edycji. Obecnie nikt oprócz jej Autora nie będzie w stanie tego zrobić w zadowalający sposób.

Wstęp zamyka prezentacja konstrukcji noty katalogowej. Autor już wcześniej, m.in. omawiając stan polskich badań sfragistycznych, zwracał uwagę na różnorodność modeli edycji sfragistycznych (s. 20, przyp. 18). W passusie tym (tzn. opisującym notę katalogową) spotykamy jednak sporo uproszczeń, być może wynikających z dążenia do zwięzłego przedstawienia złożonej wszak problematyki doboru metody prezentacji źródeł. Nie wchodząc w szczegóły, chciałbym zwrócić uwagę na kilka z nich. Autor deklaruje, że przyjęta przezeń metoda wydawnicza nawiązuje do schematu „tradycyjnej szkoły”. Przeciwstawia

\footnotetext{
${ }^{3}$ Na podobieństwa zwraca uwagę J. Wroniszewski; tenże, Średniowieczne pieczęcie, s. $238 \mathrm{n}$.

${ }^{4}$ Zob. M. Hlebionek, Pieczęcie starostów bydgoskich w zasobie A[rchiwum] P[aństwowego w] B[ydgoszczy], „Kronika Bydgoska”, 28, 2006, s. 322-332; tenże, O pieczęciach starosty generalnego Wielkopolski Adama Sędziwoja Czarnkowskiego, „Archiwa - Kancelarie - Zbiory”, 2 (4), 2011, s. 22 n. Inne stanowisko reprezentują: J. Łosowski, Pieczęcie starostów chetmskich od drugiej połowy XVI do XVIII w., w: Pieczęć w Polce średniowiecznej i nowożytnej, red. P. Dymmel, Lublin 1998, s. 153 n.; M. Adamczewski, Pieczęcie urzędowe władz lokalnych z obszaru Polski centralnej, cz. 2: Pieczęcie sądów szlacheckich do 1793 r., Łódź 2010, s. 13; zob. też uwagi Jakuba Rogulskiego (Pieczęcie herbowe książąt Sanguszków, w: Dawne pieczęcie. Typologia - metody badań - interpretacje, red. Z. Piech, Warszawa 2015, s. 437-439, 471 n.), który na podstawie badań pieczęci Sanguszków zanegował w ogóle sens wyodrębniania osobnej grupy pieczęci urzędniczych (starościńskich). Ostatnio w kontekście pieczęci używanych przez starostów zatorskich i oświęcimskich stanowisko w tej sprawie zajął K. Nabiałek, Pieczęcie starostów księstw oświęcimskiego i zatorskiego do 1563 roku, Rocz. Hist., 85, 2019, s. 112 n.
} 
ją też - jego zdaniem - „forsowanemu” obecnie modelowi wykorzystywanemu w niektórych publikacjach archiwalnych, który określa zresztą słusznie mianem ewidencyjno-informacyjnego (s. 35) ${ }^{5}$. Ów przyjęty przez Autora model odwołuje się do katalogów pieczęci autorstwa Stefana Krzysztofa Kuczyńskiego i Zenona Piecha ${ }^{6}$. Autor zmodyfikował go jednak na podstawie propozycji opisu pieczęci opracowanej przez Międzynarodowy Komitet Sfragistyczny. Na marginesie trzeba zauważyć, że ewidencyjno-informacyjny archiwalny model opisu materiałów sfragistycznych też odwołuje się do zaleceń Międzynarodowego Komitetu Sfragistycznego, będącego wszak organem Międzynarodowej Rady Archiwów.

Od strony strukturalnej konstrukcja katalogu opiera się na czterech poziomach opisu: 1) rodzina, 2) dysponent, 3) typ (wzorzec) pieczęci dysponenta, 4) egzemplarz w ramach typu (wzorca) pieczęci. Na poziomie opisu typu pieczęci Autor wyróżnia dwie warstwy: merytoryczną i dokumentacyjną, z których pierwszą dzieli dalej na zbiory informacji o charakterze klasyfikacyjnym, ikonograficznym i tekstowym. Część wspólną dla wszystkich poziomów opisu stanowi pole przeznaczone na uwagi, w którym, zależnie od potrzeby, znajdują się komentarze edytorskie mogące dotyczyć każdego z powyższych poziomów. Na opis rodziny składają się zestawienia publikacji jej dotyczących, często uzupełnione przez dość szerokie komentarze prostujące bądź uzupełniające stan wiedzy na jej temat w ogólności, a jej poszczególnych przedstawicieli w szczególności. Szkic kontekstu genealogicznego na poziomie dotyczącym rodziny pozwolił Autorowi zredukować opis realnego, jednostkowego dysponenta pieczęci do podania jego imienia, a w przypadku imion często powtarzających się w ramach rodu również identyfikatora ujednoznaczniającego hasło. Opis na poziomie typu otwiera jego oznaczenie (literowe). Poziom ten rozpoczyna określenie chronologii jego funkcjonowania. Zbiór danych klasyfikacyjnych na tym poziomie opisu tworzą informacje o kształcie pieczęci, jej rozmiarach, a wreszcie wskazanie jej typu w ramach klasyfikacji pieczęci herbowych zaproponowanych przez Z. Piecha7 . Pozostałe dwa zbiory danych na tym poziomie (ikonograficzny i tekstowy) zawierają odpowiednio opis pieczęci (będący często sumą opisów zachowanych w różnym stanie odcisków) oraz transkrypcję legendy i jej krótką charakterystykę paleograficzną. Ta ostatnia została dość luźno oparta na modelu zaproponowanym także przez Międzynarodowy Komitet Sfragistyczny (w zakresie rozwiązań szczegółowych), choć równie blisko jej do rozwiązań wykorzystywanych przez S.K. Kuczyńskiego (np. w zakresie konsekwentnego oddawania inskrypcji majuskulnych wielkimi literami, z pominięciem oznaczania pojawiających się w nich znaków minuskułowych - jak w katalogu pieczęci piastowskich Z. Piecha ${ }^{8}-$ czy $^{-}$ lakonicznej charakterystyki paleograficznej) ${ }^{9}$. Część dokumentacyjna odnosi się zarówno do typu pieczęci, jak i poszczególnych jego egzemplarzy. W pierwszym przypadku dotyczy to bibliografii i w zasadzie fotografii. Do konkretnych egzemplarzy prowadzi z kolei zestawienie sygnatur. Jak już wspomniano, pole „uwagi” ma charakter hybrydowy i może zawierać informacje odnoszące się do każdego ze scharakteryzowanych wyżej poziomów. Przyjęcie powyższej perspektywy jeszcze dobitniej pokazuje, że w sferze struktury opisu sfragistycznego różnice między stosowanym tu modelem a archiwalnym modelem ewidencyjno-informacyjnym są nieduże i sprowadzają się do szerokości prezentacji dysponenta i komentarza edytorskiego w pierwszym przypadku oraz szerokości opisu jednostkowego egzemplarza w drugim. I trudno, żeby było inaczej. To, co Autor może modelować i korygować, to dobór specyficznych dla danej formy przekazu pieczęci (tłok, odcisk, odlew, fotografia) elementów opisu formalnego oraz komentarz edytorski, węższy przy opisach archiwalnych, szerszy, choć nie zawsze, przy opisach naukowych. Z prawa tego skorzystał Autor interesującej nas edycji, wyłączywszy z formularza opisu pieczęci informacje na temat materiału, w którym wykonano odcisk oraz opisu wiązadeł. Posunięcie takie Autor uzasadnia ograniczonym wpływem dysponenta na dobór owych elementów w momencie wystawiania dokumentu. Wydaje się jednak, że jest to trochę zbyt daleko idący skrót myślowy. Rycerze bowiem sami wystawiali dokumenty i nawet jeżeli korzystali z usług skryptorium klasztornego czy pisarza miejskiego, to trudno wykluczyć ich wpływ na interesujące nas elementy pieczęci. Poza tym niewątpliwy jest ich wpływ pośredni na barwę masy woskowej ${ }^{10}$. Jako wpływ pośredni rozumiem tu odzwierciedlenie, poprzez

\footnotetext{
${ }^{5}$ W tym miejscu czuję się trochę „wywołany do tablicy” przez Autora, jako ilustrację owego przeprowadzanego na siłę czy wręcz narzucanego (tak rozumie słowo „forsować” słownik synonimów) modelu przywołał on bowiem inwentarz pieczęci z Archiwum Państwowego w Bydgoszczy mojego autorstwa. Pragnę uspokoić Czytelników i Autora, że ani ja, ani środowisko archiwistów i badaczy pieczęci, z którymi współpracuję, nie stawia sobie za cel narzucania komukolwiek czegokolwiek. Staramy się jednak, aby proponowane przez nas rozwiązania miały solidne podstawy teoretyczne. Stąd też osobne studia mające na celu zrozumienie struktury informacyjnej pieczęci, ale też analizujące rozwiązania opisowe z innych krajów. Stąd też przyjmowanie naszych rozwiązań, jako punktu odniesienia, przy ocenie innych prac o charakterze katalogowym. To ostatnie służyć ma głównie porównywaniu modeli inwentarzy/katalogów dla wychwycenia, które z elementów się sprawdziły, a które nie. Celem nadrzędnym tych działań jest wypracowanie uniwersalnego (ponieważ archiwiści mają do czynienia z pieczęciami różnych dysponentów) modelu, głównie archiwalnego, opisu pieczęci, z jednej strony ergonomicznego (szczególnie przy opisie pieczęci pojawiających się masowo: w dziesiątkach czy setkach egzemplarzy), z drugiej zaś umożliwiającego poszerzenie podstawy źródłowej badań sfragistycznych. A więc realizującego jeden z postulatów stawianych przez Autora. Uważam, że okres renesansu badań sfragistycznych, który Autor opisuje, należy wykorzystać do eksperymentów edytorskich, testujących różne rozwiązania. Sam też staram się tak działać, dostosowując modele wydawnicze do specyfiki materiału, który przygotowuję do wydania; zob. np. M. Hlebionek, Katalog pieczęci przy dokumentach samoistnych w zasobie Archiwum Państwowego w Bydgoszczy, Warszawa 2012, ss. 543; Pieczęcie przy dokumentach Związu Pruskiego. Akt erekcyjny i dokumenty akcesyjne, wyd. M. Hlebionek, Torun 2017 , ss. 401. W efekcie tych prób powinien zostać wypracowany fundament teoretyczny, z którego będą mogły korzystać późniejsze edycje. Dlatego też z radością przyjmuję nową propozycję rozwiązania problemów edytorskich, którą stworzył Autor recenzowanej pracy.

${ }^{6}$ S.K. Kuczyński, Pieczęcie książąt mazowieckich, Warszawa 1978, s. 249-420; Z. Piech, Ikonografia pieczęci Piastów, Kraków 1993 , s. $199-253$.

${ }^{7}$ Z. Piech, Pieczęcie herbowe w systemach sfragistycznych dawnej Rzeczypospolitej, w: Dawne pieczęcie, s. 220 n.

Tenże, Ikonografia, s. 199-253.

9 S.K. Kuczyński, Pieczecie książąt mazowieckich, s. 250 n.

${ }^{10}$ Ostatnio wiedzę na temat dokumentów rycerskich, w tym śląskich, podsumował T. Jurek, Funkcjonowanie dokumentu prywatnego, w: Dyplomatyka staropolska, red. T. Jurek, Warszawa 2015, s. 140-143; tenże, Dokument prywatny w późnym średniowieczu, w: tamże, s. 431-468; tenże, Zarys dyplomatyki śląskiej w późnym średniowieczu, w: tamże, s. 507. Tam najważniejsza wcześniejsza literatura przedmiotu.
} 
dobór barwy wosku, pozycji społecznej dysponenta pieczęci: uszanowanie przez realnego wystawcę dyplomu znaczenia rycerza w jego środowisku. Świadectwem tego są dość często pojawiające się w katalogu przypadki pieczętowania w masie woskowej o czerwonej, reglamentowanej barwie ${ }^{11}$. Informacja o kolorze masy woskowej w tym ujęciu jest więc istotna poznawczo i to nie tylko dla sfragistyka, ale też genealoga. Niemniej w efekcie fuzji elementów zaczerpniętych z różnych modeli opisu powstała nowa, generalnie udana w mojej ocenie, jakość (zob. niżej).

Pieczęcie osób prywatnych, tak rycerskie, jak szlacheckie czy mieszczańskie, stanowią szczególnie niewdzięczny materiał badawczy. Decydują o tym z jednej strony trudności merytoryczne, które Autor zaprezentował we wstępie, z drugiej zaś wiele kwestii technicznych, w tym niewielkie rozmiary i często słaby stan zachowania odcisków. Nie bez znaczenia jest wreszcie ich unikatowość, powodująca brak materiału porównawczego. Zjawiska te komplikują sporządzenie opisu publikowanych odcisków, który miałby stanowić dla odbiorców katalogu substytut samych źródeł. W tym kontekście szczególnego znaczenia nabierają towarzyszące opisom fotografie pieczęci dokumentujące materiał, ale też umożliwiające weryfikację opracowanego przez wydawcę opisu. Większość publikowanych w katalogowej części książki fotografii została wykonana przez Autora. Niestety, nie zawsze są one najlepszej jakości. Często zawodzi głębia ostrości, bardzo istotna w przypadku makrofotografii, z którą mamy tu do czynienia. Powoduje to, że albo reprezentacja całego odcisku, albo jego części jest niewyraźna. Mankamentem jest też brak wykorzystywania bocznego oświetlenia, które umożliwia uwydatnienie słabiej odciśniętego reliefu tak z pola legendy, jak i pola pieczęci. Niekiedy cień rzucany przez kołnierz miseczki woskowej na pole legendy sprawia, że znaczne fragmenty inskrypcji są nie do odczytania (np. Katalog, nr 195, s. 266). Podobne zastrzeżenia można mieć do fotografii odcisków wykonanych w masie woskowej o ciemnych barwach, na których relief odcisku jest ledwo widoczny (np. Katalog, nr 30, s. 138 ; nr 84 , s. 175 ; nr 95 , s. 181 ; nr 185, s. 257; nr 269, s. 323, ilustracja pierwsza do nr. 329, s. 379). Ich czytelność - być może - dałoby się poprawić przez obróbkę w odpowiednim programie graficznym. Formułując powyższe uwagi, zdaję sobie sprawę z uwarunkowań technicznych utrudniających fotografowanie, na które składają się chociażby warunki w czytelniach archiwalnych, nie zawsze umożliwiające wykonanie zdjęcia odpowiedniej jakości, ale też właściwości samych pieczęci jako obiektu fotografowanego, często powodujące trudności z czytelnym oddaniem reliefu.

Pozostając przy ilustracjach, warto postawić pytanie o sens publikacji „podobizn” pieczęci niezachowanych: pustych misek lub odcisków całkowicie zatartych. Oczywiście o ile nie towarzyszą one innym danym pozwalającym na ustalenie legendy i wyobrażenia napieczętnego. O ile w przypadkach, kiedy zdjęcia zniszczonych odcisków uzupełniają ich wcześniejsze podobizny (np. Katalog, nr 747, s. 742 n.), działanie takie można uznać za formę dokumentowania postępującej destrukcji zabytku, jednak kiedy Autor podaje wyłącznie zdjęcie pustej miski pieczętnej (np. Katalog, nr 693, s. 701) lub całkowicie zatartego bądź wykruszonego odcisku (np. Katalog, nr 150, s. 230; nr 363, s. 410; nr 581, s. 610; nr 805, s. 793; nr 833, s. 821; nr 889, s. 872), to ilustracja taka nie przynosi żadnej informacji istotnej dla badacza. Może poza odnotowaniem faktu, że dany rycerz prawdopodobnie pieczęcią dysponował (choć mógł użyć przecież pieczęci użyczonej bądź karencyjnej). Wszak nawet określenie wymiarów odcisku na podstawie rozmiaru miski pieczęci może być wyłącznie szacunkowe (por. np. nr 695, s. $701 \mathrm{n}$., gdzie widoczna spora przestrzeń między krawędzią odcisku a brzegiem miski).

Do problemu wymiarowania pieczęci Autor nie zawsze podchodzi konsekwentnie. Uwaga ta dotyczy pieczęci zachowanych fragmentarycznie, dla których czasem informacja o wymiarach została podana (np. Katalog, nr 332, s. 381; nr 130, s. 212 - wymiary zrekonstruowane), czasem zaś nie (np. Katalog, nr 13, s. 125; nr 563, s. 594). W tym pierwszym przypadku nie dowiadujemy się, czy zwymiarowany został zachowany w odlewie fragment odcisku, czy też jest to rekonstrukcja pierwotnych wymiarów pieczęci. Tymczasem Vocabularium internationale sigillographicum, do którego odwołuje się Autor jako jednego z filarów stworzonego przezeń modelu opisu pieczęci, precyzyjnie wskazuje, że o ile jest to możliwe należy rekonstruować wymiary całego odcisku (podając je w nawiasie kwadratowym), jeżeli zaś nie, to podać należy wymiary zachowanego fragmentu pieczęci (w nawiasie okrągłym) ${ }^{12}$. Podobne drobne odstępstwa od zaprezentowanego we wstępie wzoru znajdujemy w przypadku transkrypcji legendy. Tu, inaczej niż chce Vocabularium ${ }^{13}$, Autor nie opisuje dywizorów, a stara się je odwzorować za pomocą znaków graficznych. Duże zróżnicowanie tych znaków powoduje, że starania te nie zawsze kończą się sukcesem i być może lepszym rozwiązaniem byłoby jednak zastosowanie ich opisu. W niektórych przypadkach mamy do czynienia z niezbyt precyzyjną transkrypcją legendy. Autorowi zdarza się nie oznaczać w odczycie miejsc zniszczonych (np. Katalog, nr 14, s. 126 - gdzie jedyny publikowany egzemplarz ma widoczne uszkodzenia pola legendy, zaznaczone też w przytoczonej propozycji lekcji podanej przez czeskich archiwistów, czy nr 124, s. 206). Czasem też wskazanym byłoby wyjaśnienie, na czym oparł Autor rekonstrukcję treści legendy oznaczonej przezeń jako całkowicie nieczytelna (zob. np. Kata$\log , \mathrm{nr} 5$, s. 117). Niekiedy nawet na podstawie materiału ilustracyjnego zaproponować można nieco inne, niż podane przez Autora, odczyty legendy. W przypadku pieczęci publikowanej pod nr. 195 (s. 266) według fotografii czytelna jest większa część inskrypcji niż podana w jej transkrypcji, przy założeniu, że fragment ujęty w nawias kwadratowy Autor uznaje za zniszczony lub źle odciśnięty (zgodnie z Vocabularium). Dla pieczęci nr 341 (s. 388) na podstawie fotografii można zaproponować odczyt eksplicitu legendy w formie sedall względnie svdall (ornamenty), dla nr. 342 zaś (s. 389) incipit legendy będzie brzmiał: $\mathrm{s} *$ kunrad * d(e) (litery un w imieniu Kunrad w ligaturze).

\footnotetext{
${ }^{11}$ Zob. np. Katalog, nr 3, s. 114; nr 41, s. 147; nr 64, s. 160; nr 106, s. 189; nr 109, s. 192; nr 129, s. 211 n.; nr 202, s. 271 n.; nr 249, s. 308; nr 276, s. 331 ; nr 278 , s. 332 ; nr 323 , s. 374 ; nr 365 , s. 412 ; nr 366, s. 412; nr 370, s. 418; nr 466, s. 506 n.; nr 522, s. 560; nr 561, s. 592; nr 620, s. 639; nr 668, s. 679; nr 745, s. 741.

12 Vocabularium internationale sigillographicum, red. K. Müller, L. Vrtel, M. Hlebionek, V. Keresztes, Bratislava 2016 , s. 68, § 7.

13 Tamże, s. 72
} 
Podobne drobne problemy spotykamy w przypadku opisów wyobrażeń. Wbrew zaleceniom Vocabularium i rozwiązaniom wykorzystanym przez S.K. Kuczyńskiego, choć zgodnie z praktyką stosowaną przez Z. Piecha, Autor nie opisuje linii otokowych wewnętrznych i zewnętrznych. Stosuje jednak wyjątki od tej reguły, a to dla linii otokowych tworzących rozetowe (trój- bądź czwórlistne) obramienie wokół pola pieczęci (np. Katalog, nr 51, s. 152 n.; nr 112, s. 194 n.). Przyjęcie takiego rozwiązania, a szczególnie wprowadzanie wyjątków od reguły, wymagałoby wyjaśnienia we wstępie, którego tam jednak nie znajdujemy. Bagatelizowany kształt linii otokowych może mieć istotne znaczenie dla identyfikacji typu (wzorca) pieczęci, dlatego jest ważny z punktu widzenia jakości opisu sfragistycznego. Konstruując opis wyobrażenia napieczętnego, napotykał Autor liczne problemy interpretacyjne, których rozwiązanie wymagało ogromnej erudycji heraldycznej oraz znacznej dozy wyobraźni. Figury bądź przedmioty umieszczane w tarczy herbowej czy polu pieczęci osadzone były bowiem w innych realiach kulturowych (dotyczy to tak świata symboliki, jak i kultury materialnej), co powoduje, że często wyraźne kształty są dla nas trudne do odczytania. Częściowo pomocna może być tu heraldyczna tradycja rodzinna skodyfikowana w nowożytnych kompendiach heraldyczno-genealogicznych, do której Autor się odwołuje. Ale niezupełnie, niektóre bowiem z rodzin, których pieczęcie zostały uwzględnione w katalogu, nie zostały odnotowane przez nowożytnych genealogów. Istotniejsze jest jednak, że rozumienie i opis godła mógł z biegiem czasu ulegać aktualizacji dostosowującej go do kulturowych realiów epoki, w której herbarze powstawały. Wydaje się, że w wątpliwych przypadkach Autor powinien wyraźniej, niż to czyni, zaznaczać, czy opis godła, głównie interpretację jego elementów, sformułował na podstawie danych późniejszych, czy też jest to jego własna wykładnia. Odwołajmy się do kilku przykładów. Godło umieszczone na pieczęci Konrada Kluczborka (Kreuzburg, Katalog, nr 333, s. 383) blazonuje Autor jako dwie krzyżujące się laski w kształcie krzyża. Nie można jednak wykluczyć, że mamy tu do czynienia z mieczami do polowania na dzika, które upowszechniły się w Europie później, w drugiej połowie XV w., a których cechą charakterystyczną był szeroki sztych. W przypadku pieczęci Pecza Prautitz (Katalog, nr 560, s. 591 n.) można postawić pytanie, czy rzeczywiście pierwotnie w godle herbu rodziny znajdowały się obcęgi, czy też mamy do czynienia z wyobrażeniem nożyc postrzygackich, z czasem dopiero z obcęgami utożsamionych. Zbliżone wątpliwości możemy mieć w przypadku pieczęci przedstawicieli rodziny Schildau (Katalog, nr. 705-707, s. 710 n.), których godło opisuje Autor jako haki bądź dwie gołębie głowy w różnych układach. Tymczasem rysunek godła umieszczonego na tarczy herbowej Konrada (nr 707) wydaje się bliższy nożowi do cięcia winorośli (wyraźnie zaznaczona rękojeść i sierpowate ostrze zwężające się ku nasadzie, przy braku zaznaczenia takich cech anatomicznych głowy jak np. oczy). Być może także trzy elementy widoczne na pieczęci Bernarda Schildaua należałoby interpretować w ten sposób. Przykład rodziny Schildau pokazuje jeszcze jedno zjawisko, z którym spotykamy się w pracy: otóż Autor nie zawsze wykorzystuje do opisu godła spostrzeżenia wykorzystane przy charakterystykach pieczęci innych przedstawicieli rodziny. Tu w pierwszym przypadku opisuje przedmioty umieszczone w godle raz jako haki, w pozostałych przypadkach decyduje się jednak określać je mianem gołębich głów. Podobnie postępuje opisując godła przedstawicieli rodziny Nysa (Neisse) (Katalog, nr. 467-468, s. 508 n.). Mimo iż na obu mamy najprawdopodobniej do czynienia z takim samym znakiem (w nieco innych realizacjach graficznych), to w pierwszym przypadku Autor widzi w nim ukorzenioną lilię, w drugim zaś, czytelniejszym, godło identyfikuje właściwie jako ulistniony ostrzew. Jest to zapewne refleks ostrożności Autora, zdającego sobie sprawę z niekiedy rewolucyjnych zmian zachodzących w herbach rycerskich. Kończąc tę część rozważań, podnieść trzeba kwestię terminologiczną. Błędem pojawiającym się w całej pracy jest zamienne stosowanie, niebędących na gruncie sfragistyki synonimami, pojęć odcisk i stempel. Razi to tym bardziej, że Autor deklaruje we wstępie poszanowanie ustaleń, również terminologicznych, Vocabularium internationale sigillographicum ${ }^{14}$.

Praca Marka Wójcika wprowadza czytelnika, nawet zaznajomionego z polską sfragistyką rycerską, w inny świat. Krainę niezmiernie bogatą w informacje, ale też do jakiegoś stopnia obcą. Stąd raz jeszcze należy wyrazić żal, że Autor nie podjął próby stworzenia przewodnika po owym terytorium, które - jak na razie - to on spenetrował najdokładniej. Mimo podniesionych wyżej uwag, niekiedy dyskusyjnych, niekiedy drobnych, znaczenie omawianej publikacji jest wieloaspektowe i trudne do przecenienia. Nie można jej przy tym sprowadzać jedynie do funkcji quasi-herbarza, choć na to wskazuje sam Autor (s. 35). Niewątpliwie książka jest kompendium, z którego heraldycy i genealodzy będą ustawicznie korzystali. I z takiej perspektywy praca realizuje wielokrotnie stawiany postulat włączania ustaleń sfragistycznych w inne nurty badań historycznych ${ }^{15}$. W wymiarze sfragistycznym najłatwiej dostrzegalnym walorem publikacji jest, jak już wspomniano, niespotykana liczba typów pieczęci rycerskich poddanych krytycznemu opracowaniu edytorskiemu. Dla porównania Marian Haisig w pracy o pieczęciach szlacheckich $\mathrm{z}$ archiwaliów lwowskich wydał drukiem 168 pieczęci rycerstwa i szlachty ${ }^{16}$, a z nowszych, większych publikacji edycja pieczęci przy dokumentach pokoju mełneńskiego zawiera 80 pieczęci rycerskich ${ }^{17}$, publikacja dokumentów unii horodelskiej i uwierzytelniających je pieczęci przynosi informacje o 43 polskich pieczęciach ${ }^{18}$, wreszcie edycja pieczęci przy dokumentach Związku Pruskiego objęła 71 pieczęci zachowanych oraz 5 deperditów ${ }^{19}$. Proporcje między wcześniejszymi edycjami a recenzowaną pracą dobrze ilustrują skalę projektu, który zrealizował Autor. Przy tym dawniejsze publikacje, w tym

\footnotetext{
14 Tamże, s. 112, nr 16; s. 102, nr 8.

15 M. Haisig, Osiagnięcia i postulaty w zakresie sfragistyki polskiej, St. Źródł., 4, 1959, s. 164; Z. Piech, Perspektywy polskich badań sfragistycznych, w: Pieczęcie w dawnej Rzeczypospolitej, s. 42 n.; tenże, Współczesne badania sfragistyczne w Polsce. Osiagnięcia i postulaty, „Сфрагістичний щорічник”, 1, 2011, s. 174.

${ }^{16}$ M. Haisig, Sfragistyka szlachecka doby średniowiecza w świetle archiwaliów lwowskich, Lwów 1938, ss. 76.

17 Dokumenty strony polsko-litewskiej pokoju metneńskiego z 1422 roku, wyd. P. Nowak, P. Pokora, Poznań 2004, ss. 99.

18 J. Wroniszewski, Pieczęcie przy dokumencie adopcyjnym polskiej szlachty z 1413 r., w: 1413 m. Horodlès aktai. Dokumentai ir tyrinẻjimai / Akty Horodelskie z 1413 r. Dokumenty i studia, red. J. Kiaupienė, L. Korczak, Vilnius-Kraków 2013, s. 321-358.

19 Pieczęcie przy dokumentach Związku Pruskiego, s. 53-363.
} 
większość tu przywołanych, często zawierają odciski uwierzytelniające dokumenty wielopieczętne bądź wystawione w krótkim przedziale czasowym. Ukazują one zatem sfragistykę rycerską w przekroju poziomym, pozbawionym głębszej perspektywy chronologicznej. Inaczej praca M. Wójcika, prezentująca materiał w dłuższym trwaniu. W tym kontekście bodaj jedyną analogię dla interesującego nas opracowania stanowić mogą Pieczęcie polskie wieków średnich Franciszka Piekosińskiego ${ }^{20}$.

Uważam jednak, że znaczenie pracy M. Wójcika dla sfragistyki polskiej, a chyba nie tylko polskiej, leży gdzie indziej. Dzięki połączeniu elementów genealogicznych i sfragistycznych właśnie ze wspomnianą głębią chronologiczną udało mu się stworzyć swoisty model edycji sfragistycznej, który w moim przekonaniu bardzo dobrze sprawdził się w recenzowanym katalogu. Taka, jak zastosowana przez Autora, prezentacja materiału każe przy tym spojrzeć na pieczęcie rycerskie inaczej niż dotychczas. Nie jako zatomizowany kosmos, złożony z elementów niepowiązanych ze sobą bądź o trudnych do ustalenia relacjach. A taki obraz rysował się na podstawie publikacji pojedynczych pieczęci czy edycji większych, ale zakotwiczonych w jednym punkcie na osi czasu. Tymczasem publikacja M. Wójcika udowadnia, że pieczęcie rycerskie tworzyły w ramach rodu czy rodziny spójny system. Jego elementami są pieczęcie poszczególnych osób, łączące się między sobą zróżnicowanymi relacjami, z których część znajduje swoje odzwierciedlenie w ikonografii (wspólny herb albo cymer) oraz legendach napieczętnych (np. poprzez predykaty jak wskazanie filiacji czy odwołanie do wspólnego dla rodziny nazwiska), część zaś możliwa jest do uchwycenia właśnie dopiero dzięki połączeniu badań sfragistycznych z genealogicznymi i nie pozostawia zazwyczaj śladów w sferze materialnej (np. dziedziczenie pieczęci). Jest to system czuły zarówno na wpływ czynników wewnętrznych (dywersyfikacja pieczęci w ramach poszczególnych linii rodu), jak i zewnętrznych (otoczenie kulturowe). A ponieważ jest to system wytworzony przez wspólnotę o mniej sformalizowanym charakterze niż te, które były do tej pory badane (miasta, zakony), stąd na jego kształt wpływ mogły mieć trudne do uchwycenia dziś determinanty, niekiedy nawet o osobistym charakterze. System taki może mieć wreszcie wiele elementów wspólnych z innymi systemami sfragistycznymi (jak choćby pieczęcie duchownych rycerskiego pochodzenia, w sferze ikonografii odwołujące się często do wspólnoty rodowej, a w logosferze wskazujące na rodzinę, ale i na przynależność do stanu duchownego). Podejście, jakie zaproponował M. Wójcik, musi mieć wpływ na postrzeganie funkcjonowania pieczęci przez pryzmat modeli systemów sfragistycznych. A to z tego względu, że mamy tu do czynienia z systemami de facto bez dysponenta, a więc czynnika, który w świetle dotychczasowych definicji spajał owe systemy ${ }^{21}$. Tymczasem ród czy rodzina jako taka pieczęciami nie dysponowała, posiadali je natomiast (niekiedy po kilka) jej członkowie. Nie zmienia to przecież faktu, że zbiór pieczęci współrodowców łączyły, jak wyżej wspomniano, określone relacje. I właśnie takie ujęcie otwiera furtkę do analizy pieczęci rycerskich w kontekstach semiologicznych. Praca M. Wójcika nakazuje wreszcie refleksję nad jeszcze jednym zagadnieniem, które przewija się między wierszami całej recenzji. Jest to postawione jakiś czas temu przez Z. Piecha pytanie o ramy terytorialne polskich badań sfragistycznych ${ }^{22}$. A może inaczej - o sposoby przełamywania barier wynikających ze specyfiki sfragistyki terytoriów historycznych znajdujących się dziś w granicach Polski, ale dawniej luźno z nią związanych bądź niezwiązanych w ogóle. Myślę, że i w tym zakresie publikacja M. Wójcika stać się może punktem wyjścia dla inspirującej dyskusji.

Marcin Hlebionek Uniwersytet Mikotaja Kopernika

Toruń

\section{Ольга А. Климкович, Формуляр старорусских и старобелорусских дело- вых документов XIV-XVI веков, ВГУ имени П.М. Машерова, Витебск 2015, ss. 163}

Olga A. Klimkowicz zajmuje stanowisko docenta na Uniwersytecie Państwowym im. Piotra M. Maszerawa w Witebsku na Białorusi. Początkowo jej badania koncentrowały się wokół zagadnień dydaktyki języka rosyjskiego jako obcego. Z czasem jednak zwiększyło się jej zainteresowanie problematyką historii języka, czego efektem są liczne publikacje poświęcone zasadniczo zasadom konstruowania staroruskich i starobiałoruskich dokumentów. Książka skupia się głównie na aspektach językowych, nie sposób jednak nie docenić jej wartości także dla historycznych badań źródłoznawczych. O.A. Klimkowicz zbiera i porządkuje szeroką wiedzę dotyczącą dawnych dokumentów o charakterze urzędowym (деловые документы), a konkretnie umów kupieckich (купеческие грамоты), testamentów (духовные грамоты) i aktów donacyjnусh (жалованные грамоты), jednocześnie wysuwając własne propozycje terminologiczne i sposoby klasyfikacji. Tego typu dokumenty od lat

${ }^{20}$ F. Piekosiński, Pieczęcie polskie wieków średnich, cz. 1: Doba piastowska, Kraków 1899, ss. 290; tenże, Pieczęcie polskie wieków średnich doby piastowskiej, „Wiadomości Numizmatyczno-Archeologiczne”, 16, 1934, s. 71-86; 17, 1935, s. 55-78 (obie części wydane łącznie jako osobna odbitka w 1936 r.).

${ }^{21}$ System sfragistyczny to, według Z. Piecha, Średniowieczne pieczęcie tynieckie, w: Benedyktyni tynieccy w średniowieczu, red. K. Żurowska, TyniecKraków 1995, s. 123: „wzajemnie skorelowany układ odpowiadający ustrojowi, strukturze i hierarchii kompetencji [dysponenta]. Jego zewnętrznym wyrazem było wyobrażenie napieczętne, z reguły zróżnicowane treściowo (ikonograficznie), [...] oraz legenda, która towarzyszyła przedstawieniu i werbalnie identyfikowała dysponenta pieczęci”.

${ }^{22}$ Tenże, Perspektywy polskich badań sfragistycznych, s. 40. 
stanowią nieocenione źródło wiadomości nie tylko o języku epoki, w której były tworzone, ale również o samej epoce - panujących w niej uwarunkowaniach politycznych i społecznych. W tym miejscu należy zauważyć, że tytuł pracy (nieuzupełniony podtytułem) można uznać za nieco mylący. Przedmiotem badania i późniejszego opisu jest nie ogół aktów prawnych z okresu XIV-XVI w., lecz tylko ich trzy wskazane wcześniej typy. Tym samym praca nie obejmuje całości zagadnienia zasugerowanego w tytule, pomijając chociażby bardzo liczne umowy zawierane przez reprezentantów innych niż kupiectwo warstw społecznych. We wstępie Autorka informuje, że dokumenty, które sporządzano na okoliczność przekazywania dóbr, stanowią ważne źródło wiedzy o języku i realiach historycznych, nie tłumaczy jednak faktu pominięcia dokumentów innego typu, których wartość dla tych samych celów również jest istotna. Oczywiście przyczyny zawężenia pola badawczego i ograniczenia materiałowe są w pełni zrozumiałe, niemniej warto byłoby już w tytule określić korpus tekstów podlegających analizie.

Autorka obejmuje badaniem zarówno teksty wydane drukiem we wcześniejszych publikacjach dokumentów staroruskich, nр. Грамоты Великого Новгорода и Пскова (Moskva 1949), Духовные и договорные грамоты великих и удельных князей XIV-XVI вв. (Moskva 1950), jak i w zbiorach tekstów starobiałoruskich: Беларускі apxiy̆ (Archivum Alboruthenicum) (Minsk 1930), Тастаменты шляхты і мяшчан Беларусі другой паловы XVI cm. (з актавых кніг Нацылянальнага гістарычнага архіва Беларусі) (Minsk 2012), Акты, издаваемые Комиссиею, высочайше учрежденною для разбора древних актов в Вильне (t. 1-9 і 17, Vilna 1865-1895), Метрыка Вялікага Княства Літоўскага (Minsk 2003). Okres historyczny, w którym sporządzono badane dokumenty, to XIV-XVI w. Jest to czas, na który przypada zarówno stopniowy wzrost potęgi Księstwa Moskiewskiego i kształtowanie się rosyjskiej państwowości, jak i epoka rozkwitu Wielkiego Księstwa Litewskiego. We wstępie Autorka wskazuje, że analiza obszernego korpusu (1449) tekstów pozwala uzupełnić wiedzę dotyczącą rozwoju poszczególnych gatunków dokumentów urzędowych oraz po raz pierwszy opisać z punktu widzenia stylistyki lingwistycznej teksty powstałe w Wielkim Księstwie Litewskim. Jednocześnie zwraca uwagę na czynniki historyczne, które wpływały na kształtowanie się normy języka literackiego w ogóle i formularza stylu kancelaryjnego w szczególności, na terenach Wielkiego Księstwa Litewskiego, Wielkiego Księstwa Moskiewskiego i Księstwa Nowogrodzkiego.

W rozdziale I Autorka przedstawia zwięzłą charakterystykę dokumentów urzędowych jako obiektów badania historyczno-stylistycznego. Określa stosunek stylu urzędowego do języka literackiego, po czym precyzuje rozumienie terminu ,gatunek" (жанр), wskazując na potrzebę wyznaczenia cech gatunkowych badanych dokumentów, co wyraźnie wpisuje się we współczesne podejście do badania tekstów. Nawiązując do definicji wypracowanej przez Anatolija N. Kaczałkina, białoruska Badaczka rozumie gatunek tekstu urzędowego jako „klasę dokumentów połączonych wspólną modalnością tekstową, tj. stosunkiem tekstu do rzeczywistości” (s. 16, tłum. M.W.). Ponadto akcentuje konieczność wskazania celu tworzenia dokumentu jako podstawy określenia jego przynależności gatunkowej. Tym samym definiuje: 1) umowy kupieckie jako teksty spisywane dla zatwierdzenia prawa przejścia własności od jednej osoby do drugiej; 2) testamenty jako materiały tworzone w celu określenia przynależności całego majątku w przypadku śmierci; 3) akty donacyjne jako dokumenty poświadczające już istniejące lub nadanie nowych przywilejów (majątkowych, podatkowych, sądowych). Przedstawione przez O.A. Klimkowicz pozostałe kryteria klasyfikacji (s. 20) należy uznać za ciekawą propozycję, wartą powielania przy ewentualnej analizie genologicznej kolejnych zabytków piśmienniczych. Szczególnie interesujące wydaje się położenie nacisku na konieczność wzięcia pod uwagę elementów pozajęzykowych przy ustalaniu przynależności gatunkowej tekstów, np. czasu stworzenia aktu prawnego w stosunku do okresu jego pozostawania w mocy, relacji między nadawcą i adresatem jako osobami prawnymi. Również kolejny podrozdział - dokładny opis uczestników aktu komunikacyjnego z uwzględnieniem ich pozycji społecznej - pokazuje, że Autorka dostrzega zasadność rozpatrywania kontekstu przy analizie tekstów. W następnym podrozdziale przedstawione zostały definicje podstawowych (stricte językoznawczych) pojęć stosowanych przy opisie dokumentów: stała konstrukcja (устойчивая конструкиия), formuła (формула), stały związek wyrazowy (устойчивое сочетание), luźny związek wyrazowy (свободное сочетание). Konieczność ich przytoczenia dyktowana jest odmiennym rozumieniem tych terminów przez różnych autorów, na co wskazuje sama Autorka. Warto odnotować wyeksponowanie przez O.A. Klimkowicz problematyki frazeologicznej, metaforycznej, metonimicznej lub terminologicznej umowności znaczenia formuły.

Kolejne trzy rozdziały stanowią trzon pracy. Pierwszy z nich (rozdział II) zawiera opis strukturalnej i znaczeniowej organizacji tekstu. Na uwagę zasługuje fakt, że opis ten prowadzony jest osobno dla trzech, wydzielonych wcześniej przez Autorkę, części dokumentu - początku (зачин), końca (концовка) i właściwej części treściowej (содержательная часть). Ten nieskomplikowany podział w pełni oddaje różnorodność sytuacji, w jakiej każda z części była tworzona. Jak wielokrotnie wskazuje się w literaturze przedmiotu, początek i koniec dokumentu znacząco różnią się od pozostałej jego części, głównie poziomem sformalizowania. Tym samym obecność konkretnego wyrażenia, np. sposobu zwrotu do adresata czy określenia tożsamości nadawcy w danej części, może być podyktowana nie tyle przez niezależną decyzję autora, ile przez tradycję pisarską. Obserwacje poczynione przez O.A. Klimkowicz potwierdzają, że wyróżnienie wskazanych części przy analizie standardowych dokumentów urzędowych jest zasadne i użyteczne.

Bliższa charakterystyka powtarzalnych wyrażeń z tekstów dokonana została w rozdziale III. Stanowi on właściwie opatrzoną komentarzami listę zwrotów podzielonych, po pierwsze, z uwzględnieniem wcześniej wzmiankowanej klasyfikacji na formuły, stałe związki wyrazowe i luźne związki wyrazowe, następnie według przynależności gatunkowej (konstrukcje w umowach kupieckich, testamentach i aktach donacyjnych), ich przeznaczenia (np. kupno-sprzedaż, określenie wartości transakcji w wypadku umów kupieckich), a dalej zgodnie z językiem dokumentu - staroruskim lub starobiałoruskim. Analizę przeprowadzono rzetelnie, a płynące $z$ niej wnioski poparto wieloma przykładami. Pewne zastrzeżenia budzić może jedynie sama forma prezentacji wyników - liczne podziały, niewyróżnione w tekście jako kolejne podrozdziały, mogą być trudne w odbiorze i sprawiać wrażenie chaotycznych. Wygodne mogłoby być ujęcie uproszczonego zestawu formuł i wyrażeń w formie tabeli. 
Nie obniża to jednak wartości uzyskanych rezultatów. Na uwagę zasługuje również fakt, że w formie osobnego podrozdziału Autorka zaprezentowała te wyrażenia, które odnoszą się do osób biorących udział w danym akcie komunikacyjnym, dzieląc je na określenia osób indywidualnych i zbiorowych oraz oficjalnych i prywatnych. Takie wyróżnienie dowodzi, że terminy odnoszące się do osób stanowią niejako odrębną kategorię formuł, uniwersalną dla wszystkich typów dokumentów, bez względu na ich przynależność gatunkową, choć można wskazać (co czyni sama Autorka) na pewne różnice, wynikające głównie z faktów pozajęzykowych.

Rozdział IV poświęcony jest tekstotwórczym elementom obecnym w analizowanych dokumentach. Autorka na poziomie leksykalnym, syntaktycznym i stylistycznym ukazuje sposoby konstruowania aktów prawnych różnego typu jako spójnych tekstów. Takie podejście wpisuje się w popularny w ostatnich latach nurt obierania za przedmiot badania tekstu jako całości. Opracowania, w których stosuje się tego typu ujęcie w odniesieniu do tekstów historycznych, wciąż są stosunkowo rzadkie.

W zwięzłym podsumowaniu Autorka, oprócz wielu uwag natury filologicznej (przede wszystkim o celu spisania dokumentu jako podstawie określenia jego przynależności gatunkowej, hierarchicznym charakterze organizacji bloków znaczeniowych oraz stopniowym wzroście złożoności samych dokumentów w kolejnych wiekach), ponownie podkreśla konieczność uwzględniania elementów pozajęzykowych przy badaniu dawnych aktów prawnych. Nadając pracy logiczny i kompletny charakter, jednocześnie czyniąc zadość postawionej przez siebie we wstępie tezie, w zakończeniu pracy wskazuje na te elementy kontekstu (warunki tworzenia dokumentu, tożsamość nadawcy i odbiorcy), które wywarły wpływ na ostateczny kształt i dobór środków językowych w poszczególnych typach dokumentów.

Krótki słowniczek (12 haseł) umieszczony na końcu publikacji zbiera użyte w monografii terminy opatrzone stworzonymi przez Autorkę definicjami. O.A. Klimkowicz, ustosunkowując się w monografii do stanowisk różnych badaczy, wysuwa własne propozycje terminologiczne. Szczególną uwagę warto zwrócić na definicje początku (зачин), kоńса (кониовка) i głównej części treściowej (содержательная часть) dokumentu, a także formularza (формуляр) jako zestawu następujących po sobie bloków znaczeniowych (смысловой блок) i konstrukcji służących ich werbalizacji. Jak dowiodła analiza Autorki, stosowanie pojęcia „bloku znaczeniowego” jest bardzo praktyczne dla scharakteryzowania struktury dokumentu i pozwala na precyzyjne przypisanie tekstu do określonego gatunku.

Dołączona do publikacji obszerna bibliografia wykorzystanych prac (426 pozycji) z jednej strony wskazuje na bogate czerpanie z dotychczasowych osiągnięć językoznawstwa historycznego i stylistyki, z drugiej natomiast obnaża pewną słabość badania o takim charakterze, jakiego podjęła się Autorka. Z tak licznych pozycji tylko dwie nie są napisane w języku rosyjskim lub białoruskim (są to prace niemieckojęzyczne poświęcone językowi kancelaryjnemu). Taki spis bibliograficzny nie świadczy bynajmniej o złym przygotowaniu Autorki. Wskazuje raczej na duży poziom zamknięcia badań tekstologicznych w ramach jednego kręgu kulturowego bądź językowego. W dużym stopniu ogranicza to możliwość rozwoju tej dziedziny badań na poziomie przekraczającym poziom jednego języka. W tym przypadku jest to szczególna strata dla badań slawistycznych, jako że utrudnia wymianę wiedzy i jej porównywanie dla wypracowania pełnego obrazu rozwoju kultury piśmienniczej Słowian. Choć dostępna tylko w wersji rosyjskojęzycznej, praca O.A. Klimkowicz w istotny sposób wzbogaca wiedzę na temat wschodniosłowiańskiego formularza dokumentów prawnych i, szerzej, rozwoju piśmiennictwa urzędowego i kształtowania się języków literackich wschodnich Słowian. Może zainteresować szerokie grono archiwistów, historyków, historyków języka.

Maciej Waraczewski

Uniwersytet im. Adama Mickiewicza

Poznań

The Correspondence of John of Capistrano, t. 1: Letters Related to the History of Poland and Silesia (1451-1456), wyd. Pawel Kras, Halina Manikowska, Marcin Starzyński, Anna Zajchowska-Bołtromiuk [współpr. Maria Koczerska, Marek Daniel Kowalski, Mieczysław Mejor, Letizia Pellegrini, Stephen Rowell, Filippo Sedda], tlum. na ang. Stephen Rowell, Tadeusz Manteuffel Institute of History. Polish Academy of Sciences - Wydawnictwo KUL, Warsaw-Lublin 2018, ss. 325, il.

Tom zawierający 56 listów łacińskich z korespondencji Jana Kapistrana (w tym 11 jego własnych i 45 skierowanych do niego), związanych z historią Polski i Śląska, to publikacja źródłowa przygotowana przez polskich członków międzynarodowego zespołu badaczy zajmujących się korespondencją włoskiego franciszkanina, kaznodziei, nuncjusza papieskiego i propagatora reformy obserwanckiej w środkowej i wschodniej Europie. Zespół ten zorganizowany został przez Letizię Pellegrini (Uniwersytet w Maceracie) w celu skatalogowania i opublikowania całej - rozproszonej i dotychczas tylko fragmentarycznie ogłaszanej drukiem - korespondencji, obejmującej wedle najnowszych ustaleń 649 (w tym 47 zaginionych) listów z lat 1418-1456. Książka stanowi pierwszy tom serii The Correspondence of John of Capistrano; redaktorami serii, oprócz wspomnianej prof. Pellegrini, są Gábriel Klaniczay, Filippo Sedda i Ludovic Viallet. 
Teksty źródłowe poprzedza obszerny wstęp oraz nota o przyjętych zasadach edytorskich. Wstęp składa się z czterech rozdziałów i stanowi doskonałe wprowadzenie do lektury niezwykle interesującej korespondencji Kapistrana.

W pierwszym rozdziale wstępu (The Correspondence of John of Capistrano. The History of a Research Project, s. 21-34) L. Pellegrini podnosi znaczenie korespondencji jako źródła do badań nad kontrowersyjną postacią Jana Kapistrana, postrzeganego przez wielu badaczy już to jako fanatyczny obskurantysta, prześladujący Żydów i pogan, już to jako „apostoł Europy” i obrońca chrześcijaństwa. Jedynie pogłębione badania źródłowe pozwolą - zdaniem Uczonej - przełamać zniekształcenia dotychczasowych ustaleń kształtowanych przez uprzedzenia i stereotypy. L. Pellegrini zarysowuje także aktualny stan badań nad korespondencją franciszkanina oraz perypetie związane z pozyskiwaniem środków finansowych na prace zespołu.

W następnym rozdziale (Corpus Epistolarum Capistrani (CEC). An Overview of the Database of John of Capistrano's Epistolary, s. 35-46) F. Sedda dokładnie opisuje stan zachowania korespondencji, naświetla skomplikowaną sytuację w zakresie przekazów źródłowych (jedynie część listów zachowała się w postaci oryginałów-czystopisów, pozostałe znane są z kopii lub wczesnych druków), omawia dotychczasowe (cząstkowe) edycje korespondencji Kapistrana oraz historię prac nad jej inwentaryzacją. Najnowszym etapem tej inwentaryzacji jest stworzona przez Autora rozdziału cyfrowa baza danych Corpus Epistolarum Capistrani, gromadząca informacje o poszczególnych listach, ich nadawcach, adresatach i datowaniu, a także o rękopiśmiennych przekazach źródłowych oraz dotychczasowej transmisji listów, zarówno w formie publikacji, jak i rozmaitych katalogów. Na podstawie informacji z bazy danych F. Sedda prezentuje zestawienia liczbowe odnoszące się do rozmaitych aspektów badanej korespondencji - chronologicznego, geograficznego oraz prozopograficznego (osoby i status korespondentów).

W rozdziale trzecim (John of Capistrano and His Correspondence Related to the Polish Kingdom and Silesia, s. 47-67) Paweł Kras rysuje tło historyczne zarówno w odniesieniu do postaci Jana Kapistrana, ze szczególnym uwzględnieniem przyczyn i okoliczności jego podróży do krajów zaalpejskich (w latach 1451-1456 dotarł on do Austrii, Czech, Bawarii, Frankonii, Turyngii, Saksonii, Polski i Węgier), jak też do wydarzeń w Królestwie Polskim i na Śląsku podczas pobytu franciszkanina w tych krajach. Autor omawia także dotychczasowy stan badań nad tym okresem jego życia i działalności. Następnie podaje i uzasadnia kryteria wyboru listów do „polsko-śląskiego epistolarium” Kapistrana - w tomie zamieszczono bowiem wyłącznie korespondencję włoskiego zakonnika z osobami z Polski i Śląska oraz trzy listy spoza tej grupy, dotyczące początków wojny trzynastoletniej (Jan Kapistran do papieża Mikołaja V i do arcybiskupa Moguncji Dietricha Schenka oraz kardynał Mikołaj z Kuzy do Jana Kapistrana). Listów takich istnieje łącznie 56, w sześciu przypadkach jednak zły stan zachowania przekazu źródłowego umożliwił publikację jedynie krótkiego regestu, nie zaś listu in extenso. Wyłączono natomiast $\mathrm{z}$ tomu listy wysłane przez Kapistrana z Wrocławia i Krakowa do innych korespondentów (są to polemiki z czeskimi husytami) oraz odnoszące się do Kapistrana listy innych osób (np. kardynała Zbigniewa Oleśnickiego do papieża Mikołaja V czy też Jana Elgota do biskupa wrocławskiego Piotra Nowaka). Nie włączono także do tomu licznych zachowanych dokumentów bractw franciszkańskich wystawianych przez Kapistrana we Wrocławiu i Krakowie. Rozdział ten zawiera również szczegółowe dane o podstawie źródłowej publikowanych w tomie listów oraz o zakresie i jakości ich wcześniejszych publikacji. Trzynaście listów ukazuje się drukiem po raz pierwszy, kolejne cztery były wcześniej publikowane jedynie we fragmentach. Następnie P. Kras omawia główne wątki publikowanej w tomie korespondencji w powiązaniu z osobami korespondentów. Na liście 20 korespondentów (jakkolwiek Autor rozdziału dolicza się ich jedynie 18, biorąc, jak się zdaje, pod uwagę wyłącznie listy publikowane in extenso) znajdujemy władców świeckich (m.in. króla Kazimierza IV Jagiellończyka, księżnę Annę Mazowiecką) i ich urzędników, biskupów krakowskich i wrocławskich (m.in. kardynała Zbigniewa Oleśnickiego - współpracownika, a z czasem także bliskiego przyjaciela Kapistrana), kanoników (m.in. Jana Długosza), rady i rajców miejskich Krakowa oraz Wrocławia, członków zgromadzeń franciszkańskich (obserwantów i tercjarzy) oraz bliżej nieokreślonego zakonu żeńskiego.

W czwartym rozdziale wstępu (Note on the Latin Style of the Correspondence of John of Capistrano Related to the Polish Kingdom and Silesia, s. 69-83) Mieczysław Mejor poddaje publikowane listy analizie językowej w zakresie pisowni, słownictwa, frazeologii, zastosowania form grzecznościowych i środków stylistycznych (w tym użycia języka biblijnego i kryptocytatów) oraz składni, opatrując rozważania wieloma przykładami.

Nota o zasadach edytorskich (s. 85-87) odwołuje się do Instrukcji wydawniczej dla średniowiecznych źródeł historycznych Komisji Historycznej Polskiej Akademii Umiejętności (1930), podając następnie pewne uściślenia i rozbieżności z tą instrukcją. Niestety prawdopodobnie Wydawcom zabrakło czasu na dopracowanie redakcyjne noty - punkt dotyczący zastosowania wielkich liter powinien obejmować podpunkty od a. do g., kolejne podpunkty (h.-m.) powinny być głównymi punktami. Lista skrótów zastosowanych w aparacie krytycznym jest niekompletna, nie obejmuje bowiem następujących przypadków: d(extra), illeg(ibile), p(ropria), sequit(ur); skrót om. został błędnie rozwiązany jako m(issum) zamiast om(issum) - omyłka ta skłania do podejrzeń, że osobie zestawiającej skróty prawdopodobnie bliższy był język angielski niż łacina, ponieważ zamiast omissum (z łac. 'opuszczone') mamy słowo missum (z łac. 'posłane’), najpewniej pod wpływem angielskiego missing. Nie jest jasna dla czytelnika kwestia oznaczania odniesień biblijnych - Wydawcy deklarują najpierw sygnalizowanie przywołań (,biblical citations") kursywą oraz podawanie odpowiednich lokalizacji w nawiasach kwadratowych, a na następnej stronie komunikują, że similia („quotations”) będą identyfikowane w przypisach komentarza („explanatory notes”), oznaczonych numeracją arabską. Do kwestii przytoczeń jeszcze wrócę, omawiając realizację zasad edytorskich w tomie.

Na s. 89-317 znajduje się 50 listów in extenso, podanych równolegle w języku oryginału (lewa strona rozkładówki) oraz w przekładzie angielskim (prawa strona rozkładówki). Każdy list opatrzony jest nagłówkiem, złożonym z: 1) numeru kolejnego, 2) datacji, 3) krótkiego regestu zawierającego dane o nadawcy, adresacie i treści listu, informacji o 4) rękopiśmiennej podstawie źródłowej, 5) wcześniejszych edycjach, 6) referencjach w inwentarzach, 7) istniejących tłumaczeniach listu na język polski, a także 8) uwag Wydawców. Nagłówek znajduje się na lewej stronie rozkładówki. Tekst łaciński opatrzono przypisami 
aparatu krytycznego oznaczonymi literami alfabetu łacińskiego, a także (jednak wyłącznie w zakresie similiów) przypisami komentarza oznaczonymi numeracją arabską. Tekst przekładu opatrzono przypisami komentarza objaśniającymi kontekst (identyfikacja osób, miejsc oraz objaśnienia rzeczowe) i sygnalizującymi similia. Oznacza to, że przypisy sygnalizujące similia dublują się i że w obrębie każdego listu mamy do czynienia z podwójną numeracją ciągłą: jedną dla tekstu łacińskiego, drugą dla angielskiego. Rozwiązanie to wydaje się niefortunne, ponieważ - w obrębie tego samego listu - dwa takie same numery odnoszą się do dwóch różnych miejsc w tekście. Dodatkowo percepcję utrudnia wyłączenie z komentarza dosłownych przytoczeń biblijnych i sygnalizowanie ich kursywą oraz lokalizacjami podawanymi bezpośrednio w tekście, w nawiasach kwadratowych, gdy tymczasem lokalizacje pozostałych przytoczeń (raczej parafraz niż dokładnych cytatów), w większości również pochodzących z Biblii, podawane są w przypisach. Wszystkie przypisy, zarówno komentarza, jak i aparatu, umieszczono u dołu strony pod właściwym dla nich tekstem. Obszerność występującego tylko po lewej stronie nagłówka, nie w pełni kompensowana przez mniejszą objętość aparatu krytycznego w stosunku do komentarza rzeczowego, spowodowała, że teksty na rozkładówce nie korespondują ze sobą - przesunięcie przekładu w stosunku do oryginału jest znaczne: obejmuje niekiedy kilka akapitów. Tajemnicą pozostaje, dlaczego ręcznie nie przesunięto tekstu tak, aby możliwa była równoległa lektura - dla biegłego łamacza nie powinno to stanowić problemu, tym bardziej że tam, gdzie tekst łaciński kończy się wcześniej, pozostawiono puste stronice. Nie chodziło zatem o oszczędność miejsca. To zaniechanie przyniosło dwa negatywne rezultaty. Pierwszym z nich jest niewygoda czytelnika, który chciałby korzystać równocześnie z oryginału i przekładu tekstu oraz np. z komentarzy rzeczowych podczas lektury oryginału. Tymczasem jest on zmuszony szukać przypisów, przewracając kartki, i identyfikować odpowiednie fragmenty, nie widząc ich obok siebie. Drugi mankament to usterki edycji, które łatwiej dałyby się wychwycić w korekcie, gdyby oryginał i przekład były widoczne równolegle. Chodzi tu przede wszystkim o niezgodność podziału tekstu oryginału i tekstu przekładu na akapity (np. s. 257/258, 267/268), brak (wbrew deklaracji Wydawców umieszczonej na s. 86) interpunkcji w tekście oryginalnym pomimo wstawienia interpunkcji w przekładzie (np. s. 201/202), brak ujednolicenia skrótów sygnalizujących referencje biblijne (np. na s. 117 w przekładzie znajdujemy odwołanie: I Sam., na s. 118 zaś, w tym samym miejscu w oryginale: I Reg.), omyłki w takichże referencjach (np. na s. 173, w przekładzie, znajduje się prawidłowe odwołanie do Phil 3:19, które w tekście łacińskim na s. 174 zawiera błąd: Phil 13:19). Niestety tego typu uchybienia są stosunkowo częste i pojawiają się nie tylko tam, gdzie układ tekstu utrudnia konfrontację oryginału z przekładem.

Szczególnie liczne omyłki występują w przypisach rzeczowych podających lokalizację similiów (np. s. 97: lokalizacja w nawiasach kwadratowych; s. 150, przyp. $1=$ s. 151 przyp. 2, przy czym obydwa odwołania zawierają błąd: na s. 150 jest „p. 49”, na s. 151 - „pp. 49-50”, tymczasem powinno być „p. 50”; s. 172, przyp. 1 - błędnie „Eccli. 24:13” zamiast „Dan. 4:19” - w tekście łacińskim lokalizacja ta jest umieszczona wewnątrz (!) cytatu, w przekładzie zaś została pominięta; s. 202, przyp. 3 ; s. 212, przyp. 1; s. 258, przyp. 3). Niekiedy referencja podana jest - wbrew przyjętej w innych miejscach praktyce - jedynie w tekście oryginalnym (np. s. 124, przyp. 1; s. 180, przyp. 1; s. 256, przyp. 1; s. 268, przyp. 1, 2). Innego typu zamieszanie w referencjach powstało na s. 130/131, gdzie do pewnych fragmentów tekstu zastosowano redundantnie oba sposoby sygnalizowania odwołań - zarówno przypis, jak i kursywę z nawiasem kwadratowym. Można oczywiście upierać się przy celowości odróżnienia parafraz od dosłownych przytoczeń, praktyczniejszym rozwiązaniem wydaje się jednak przytaczanie cytowanego bądź parafrazowanego tekstu w przypisie, takie bowiem rozwiązanie pozwala czytelnikowi samemu ocenić, jak duże zmiany wprowadził cytujący do tekstu. Teksty referencyjne (z wyjątkiem fragmentów Biblii) są zresztą przytaczane przez Wydawców w przypisach (np. s. 124, 228/229), jednak sposób ich podawania pozostawia miejscami sporo do życzenia. Przykładowo, na s. 124 znajduje się odniesienie do listu Alberta da Sarteano OFM do księcia Burgundii Filipa Dobrego zawierające literówkę (supersede zamiast supersedeo) oraz niezasygnalizowane obszerne wypuszczenie tekstu (po słowach vices gratificationis) i kończące się w połowie zdania, mimo że zakończenie tego zdania (,deceptio falsarum laudationum gloriosis seculi hominibus frequentius turgida parere reluctareque solet") jest dosłownie przytoczone w liście Jana Kapistrana bezpośrednio po oznaczeniu przypisu. W tym samym liście na s. 126 znajdujemy kolejne zapożyczenia z tegoż listu Sarteano, nie zostały one jednak dostrzeżone przez Wydawców. Trzymając się kwestii similiów - w przyp. 2 na s. 276 (= przyp. 6 na s. 277) objaśniono datę określoną w tekście źródłowym za pomocą incipitu ewangelii („,nos hodierna die evangelica edocet veritas cum dicit: Tristicia vestra vertetur in gaudium" [Io. 16:20]) na trzecią niedzielę wielkanocną, podając przy tym datę Wielkanocy 1455 r. (tj. 6 kwietnia), z kiedy pochodzi list nr 41. Ponieważ nie było dla mnie zrozumiałe, dlaczego nie podano daty trzeciej niedzieli po Wielkanocy (27 kwietnia) pomimo prawidłowej identyfikacji tej niedzieli w przypisie, postanowiłam przyjrzeć się dokładniej datowaniu listu. Otóż oryginalna formuła datacyjna zawiera dzień 28 kwietnia, podczas gdy nagłówek listu - 8 (!) kwietnia. List jest stosunkowo długi, mógł zatem powstawać przez dwa lub więcej dni, co tłumaczyłoby użycie sformułowania „w dniu dzisiejszym” (hodierna die) w odniesieniu do dnia poprzedzającego datowanie. Wydawcy nie odnotowują jednak żadnych wątpliwości co do daty tego listu. Nie może tu być też mowy o „zagubieniu” cyfry 2 przy łamaniu tekstu, ponieważ kolejny list w edycji datowany jest na 20 kwietnia. Mamy zatem do czynienia z błędem datacji w nagłówku, którego źródła nie potrafię wyjaśnić, oraz z takim sformułowaniem przypisu, aby pozornie nie był sprzeczny z datą z nagłówka. Można tylko przypuszczać, że przypis albo został sformułowany przez osobę nieświadomą zawiłości średniowiecznej chronologii i znaczenia tekstu łacińskiego, albo powstawał w zbytnim pośpiechu i nie został ostatecznie zredagowany. Drobne usterki zawiera także przypis komentujący uwagi Wydawców do listu nr 42, w którym Długosz opłakuje śmierć kardynała Zbigniewa Oleśnickiego oraz opisuje uroczystości pogrzebowe (s. 284, przyp. 1). Wydawcy przytaczają w tym przypisie obszerny fragment żywota Oleśnickiego w edycji Mieczysława Brożka z błędami (propaganda zamiast propagando i illius modi zamiast illiusmodi).

Przypisy komentarza rzeczowego nieodnoszące się do tekstów źródłowych są opracowane znacznie lepiej. Można mieć jedynie wątpliwości, czy są one właściwym miejscem na podawanie informacji o nagłówkach kopii (np. s. 164, 200) - wydaje 
się, że lepiej byłoby zawrzeć te wiadomości w ramach opisu źródła. Również korekta błędnego zapisu daty (s. 186, przyp. 1) nie powinna znajdować się w przypisie rzeczowym - tekst powinien zostać skorygowany w aparacie krytycznym lub opatrzony przypiskiem [sic], natomiast uzasadnienie przyjętej datacji należałoby umieścić w części nagłówka zawierającej uwagi wydawców („Remarks”). Pozostaje także kwestią dyskusyjną, czy warto robić przypisy o treści „,individual unknown” (np. s. 163, 276, 283). Notabene na s. 277 zamieszczono dwa przypisy tego rodzaju odnośnie do jednej osoby, zwącej się Cristoffel Neskevicz alias Hugelsicz de Cutio in terra Slesiae, jeden przypis kładąc przy nazwisku Neskevicz, drugi zaś - przy Hugelsicz of Cutium. Co ciekawe, indeks scala tę osobę, podając jednak niewłaściwą, jak się zdaje, formę podstawową nazwiska: Neskevicz Cristoffel alias Hugelsicz de Cutio in terra Slesiae, zamiast Neskevicz alias Hugelsicz de Cutio in terra Slesiae, Cristoffel. W indeksie nie zamieszczono też odsyłaczy do nazwiska Hugelsicz ani do (niezidentyfikowanej) miejscowości Cutium na Śląsku. W kilku przypadkach zdziwienie budzi nader niewygodne dla czytelnika umiejscowienie na końcu frazy odsyłacza przypisu identyfikującego osobę występującą w tej frazie wcześniej (np. s. 171, przyp. 6; s. 197, przyp. 4), zwłaszcza że nie jest to generalna zasada lokalizowania odsyłaczy w tomie. Jeśli idzie o niezidentyfikowane miejscowości, warto byłoby sprawdzić, czy lekcji Ryono (s. 236) nie dałoby się w źródle odczytać jako Kyouo (Kijów?). Zasadniczo jednak komentarz rzeczowy jest poprawny, wyczerpujący i dobrze spełnia swoją rolę, ułatwiając czytelnikowi poruszanie się po tekście, choć byłoby to jeszcze łatwiejsze, gdyby odsyłacze umieszczono nie tylko w przekładzie, lecz także w tekście oryginalnym, oczywiście nie dublując samych przypisów.

Niestety nie da się podobnych pochwał wygłosić w stosunku do aparatu krytycznego, który sporządzono niestarannie, a niekiedy wręcz niekompetentnie. Na s. 144, 224, 276, 280, 296, 298, 306 występują następujące zaburzenia w oznakowaniu przypisów aparatu: niewłaściwa kolejność i/lub pominięcie części liter, nieadekwatność oznaczonego tekstu do treści przypisu, brak referencji do danego przypisu w tekście, brak przypisu do danej referencji, wprowadzenie kursywy do podniesionej końcówki liczebnika, co sprawia, że wygląda ona jak referencja do przypisu. Te czysto techniczne usterki dowodzą, że aparat został opracowany w pośpiechu i bez dostatecznej kontroli. Wydaje się, że nie w pełni został też przez Wydawców ustalony sposób opisywania stanu tekstu oraz traktowania jego zapisu, choć w uwagach wstępnych odwołują się do Instrukcji wydawniczej dla średniowiecznych źródeł historycznych Komisji Historycznej PAU. Przykładowo, podczas gdy instrukcja zaleca zachowanie zapisu podwójnych i pojedynczych spółgłosek, Wydawcy na s. 302 zamieniają rettulit na retulit oraz aditamento na additamento, na s. 306 jednak nie usuwają geminaty w słowie maximmus, lecz sygnalizują tę nieregularność przypiskiem [sic]. Na tej samej stronie ze zdumieniem znajdujemy też oznaczenie [sic] przy słowie suspuria (w regularnym zapisie - suspiria), na s. 228 zaś - przy słowie ewangelisatura (w regularnym zapisie - evangelizatura). Użycie tego przypisku (notabene niezalecane przez wspomnianą wyżej Instrukcję) powinno być zarezerwowane dla rażących błędów, nie zaś dla nieregularności zapisu, które - zgodnie z Instrukcja - powinny zostać w tekście zachowane. Aparat jest niekiedy pozytywny, niekiedy zaś negatywny - przykładowo przypis e na s. 276 ogranicza się do komunikatu illeg(ibile). Nie jest jasne, czy nieczytelne jest słowo frater, przy którym stoi oznaczenie przypisu, czy też jakieś następujące po nim słowo, tym bardziej że Wydawcy zadeklarowali (s. 86), że miejsca nieczytelne podają w nawiasach kwadratowych, których w omawianym miejscu nie ma. Niepokoją także przypadki aparatu pozytywnego, gdzie tekst główny został przytoczony w tekście przypisu z błędami, np. (s. 124, przyp. c) aparat do tekstu aucupationes inanium rumusculorum brzmi: aucupaciones ianium rumuculorum scr., ms. aucupacione manuum ramusculorum. Konsekwencji zabrakło także w zakresie łącznej i rozdzielnej pisowni wyrazów. Podczas gdy instrukcja zaleca tu standaryzację, Wydawcy przynajmniej w niektórych wypadkach idą za wersją źródłową, toteż znajdujemy na s. 102 zapis quando quidem (w obu prezentowanych kopiach) w miejsce regularnego quandoquidem, na s. 200 putat ne w miejsce regularnego putatne, na s. 96 in presenciarum w miejsce regularnego inpresenciarum (klasycznie impraesentiarum). Co więcej, w przypadku zapisu tego ostatniego słowa w źródle w postaci im presentiarum (s. 222) Wydawcy wprowadzają poprawkę: in presentiarum zamiast: impresentiarum. Stosowanie niepotrzebnych lub wręcz psujących tekst poprawek edytorskich jest najpoważniejszym niedociągnięciem aparatu. Tak oto na s. 102, gdzie prezentowane są równolegle dwa przekazy listu, poprawna lekcja prestaturum (łącząca się składniowo z te w konstrukcji A.c.I.) została opatrzona przypiskiem [sic], w przeciwieństwie do błędnego prestaturos. Na s. 202 błędnie poprawiono posse na posse $<t>$. Wprowadzenie tej poprawki wraz z zastosowaną w tym miejscu błędną łączliwością wyrażenia putatne dowodzi niezrozumienia składni tekstu łacińskiego (notabene Tłumacz przełożył to miejsce poprawnie, nie uwzględniając błędu Wydawców). Na s. 210 pojawia się niepotrzebna poprawka prawidłowego contempler na contemplarem (tak Wydawcy w tekście głównym) / contemplem (tak Wydawcy w przypisie!). Na s. 230 Edytorzy poprawiają wariantywny zapis accessere z druku Luke'a Waddinga na arcessere, co stoi w sprzeczności z przyjętą zasadą niekorygowania zapisu źródłowego. Na s. 242 pojawia się nieuzasadniona poprawka prawidłowej lekcji nusquam na numquam. Na s. $252 \mathrm{w}$ przypisie a (zapewne nieumyślnie pozostawionym po wycofaniu się z planowanej poprawki) Wydawcy niepotrzebnie sygnalizują swoje wahanie co do prawidłowej lekcji aequorum (w tekście występuje apozycja aequorum sive marium) i plany poprawienia jej na aquarum. (Notabene w przekładzie tego miejsca znajduje się słowo waters, co rodzi podejrzenia, że Tłumacz nie został zawiadomiony o wycofaniu się z poprawki!). Identyczna sytuacja występuje na s. 258, zawierającej tę samą apozycję, różniącą się jedynie zapisem słowa aequor bez dyftongu, opatrzoną takim samym, zbędnym przypisem aparatu. Na s. 288 Wydawcy niepotrzebnie poprawiają prawidłowe facem accendi na facem accendere, przy czym Tłumacz daje w tym miejscu zgodną ze źródłem i wewnętrzną logiką tekstu stronę bierną the torch ... would be lit. Pewien (na szczęście niezaburzający percepcji tekstu) nieporządek pojawia się też przy uzupełnianiu tekstu przez Wydawców, np. na s. 160/161 tekst łaciński ma lekcję sancte $<$ Prisce $>$, która została oddana w przekładzie jako [of St. Prisca], podczas gdy należałoby się spodziewać of St. $<$ Prisca $>$. Na s. 204/205, 206/209, 210/211, 268/269 uzupełniono stałe fragmenty daty rocznej $(<M C C C C>$, [14]), oddane w źródle przez zapis etc., pozostawiając jednak etc. w tekście i w przekładzie, podczas gdy należałoby jedynie zasygnalizować jego istnienie przypisem aparatu krytycznego. Opisane powyżej perturbacje Edytorów z aparatem krytycznym 
skłaniają do sceptycyzmu co do jakości proponowanego przez nich odczytania tekstu źródłowego. Na szczęście niezasygnalizowane przez Wydawców, a ujawniające się podczas lektury tekstu uchybienia językowe nie są liczne, np. na s. 204 wołacz A fili zamiast $O$ fili czy też na s. 228 prostati zamiast prostrati (poprawna lekcja znajduje się w edycji XIX-wiecznej i w przekładzie).

Po tekstach źródłowych na s. 319 n. zamieszczono inwentarz wspomnianych wyżej sześciu źle zachowanych oryginałów, ponumerowanych od D 1 do D 6, a następnie, na s. 321-325, indeks osób i miejsc. Indeks odnosi się jedynie do tekstów źródłowych, nie obejmuje tekstów wstępnych i komentarzy. Nazwy podano w łacińskiej formie źródłowej. Ich współczesne odpowiedniki umieszczono w nawiasach obok nazwy łacińskiej, nie wprowadzono natomiast do indeksu odsyłaczy do form wariantywnych. Nie jest to jednak znaczące uchybienie w przypadku tak krótkiego, liczącego zaledwie pięć stron, indeksu. Rozczarowanie wywołuje niestety zbyt ogólny spis treści (s. 9) - nie zawiera on bowiem wykazu poszczególnych listów, które weszły w skład tomu. Znacznie utrudnia to użytkowanie publikowanych tekstów, tym bardziej że w żywej paginie również nie podano szczegółów dotyczących korespondentów, datowania, a nawet numeracji listów, ograniczając się do rozróżnienia między rozdziałami wstępu a częścią źródłową.

Przypuszczalnie większości wyżej wymienionych usterek można byłoby uniknąć pod dwoma warunkami: po pierwsze, gdyby do prac stricte edytorskich (a nie tylko do opisu cech języka wydawanych listów) zaproszono filologa-neolatynistę, po drugie zaś (co niestety jest trudne do realizacji w systemie grantowym, wymuszającym dotrzymywanie abstrakcyjnych niekiedy terminów), gdyby Wydawcy mieli więcej czasu na dopracowanie redaktorskie i korekty książki.

Wielką zaletą prezentowanej edycji jest jej dwujęzyczność - opatrzenie łacińskiego tekstu źródłowego przekładem na język angielski oraz angielskim komentarzem znacznie poszerza krąg odbiorców publikacji. Tłumaczenie - na ile potrafi je ocenić recenzent niebędący anglofonem - jest wierne i zasadniczo wolne od usterek. Jedynym wykrytym przeze mnie błędem przekładu jest opuszczenie liczebnika „dwieście” (CC) we frazie tot animarum in numero CC, przetłumaczonej jako so many souls in number (s. 306/307).

Książka jest pięknie opracowana typograficznie, ma elegancką, sztywną oprawę, ozdobioną wyrazistym portretem protagonisty publikacji autorstwa Thomana Burgkmaira oraz reprodukcją oryginału listu skierowanego do franciszkanina przez radę miasta Krakowa. Dobór papieru i czcionki drukarskiej również powinien zadowolić gusta wymagających czytelników. Dobrą jakością graficzną charakteryzują się także ilustracje wewnątrz tomu (są to wyłącznie kolorowe wykresy zawarte w drugiej części wstępu, poświęconej bazie danych korespondencji Kapistrana; mankamentem natury redakcyjnej jest niestety niedopracowanie podpisów i legendy wykresów).

Na koniec warto odnotować, że równocześnie z omawianą edycją, w tym samym wydawnictwie i w siostrzanej oprawie graficznej, ukazał się tom studiów poświęconych działalności Jana Kapistrana na terenach zaalpejskich oraz jego korespondencji, pt. The Grand Tour of John of Capistrano in Central and Eastern Europe (1451-1456). Transfer of Ideas and Strategies of Communication in the Late Middle Ages. Tom jest dziełem zbiorowym pod redakcją naukową Pawła Krasa i Jamesa Mixsona. Zawiera on opracowania autorstwa członków międzynarodowego zespołu badawczego stworzonego przez L. Pellegrini dla jej projektu edytorskiego.

Podsumowując, w zaprezentowanym tomie badacze dziejów polskiego i europejskiego późnego średniowiecza znajdą bardzo ciekawe, niedostatecznie do tej pory eksplorowane teksty źródłowe, których wnikliwa analiza niewątpliwie otworzy drogę do nowych odkryć i interpretacji. W tym kontekście ogromnie cieszy też zapowiedź F. Seddy (s. 46), że baza danych Corpus Epistolarum Capistrani (CEC) ma wkrótce zostać udostępniona szerszemu gronu uczonych. Z niecierpliwością będziemy również oczekiwać na ukazanie się drukiem zaanonsowanego (s. 34) przez L. Pellegrini drugiego tomu serii, w którym grupa uczonych węgierskich opublikuje korespondencję Jana Kapistrana związaną z Królestwem Węgier (wraz z Transylwanią i Banatem), a także na kolejne woluminy.

Anna Skolimowska

Wydziat „Artes Liberales”

Uniwersytet Warszawski

\author{
Pontyfikal Erazma Ciolka, wyd. ks. Szymon Fedorowicz, Monumenta Sacra \\ Polonorum, t. 5, Polska Akademia Umiejętności, Kraków 2019, ss. XXXIII + \\ $[1]+295$, il. kol. 64
}

Kolejną publikację z niestety nieregularnie ukazującej się serii Monumenta Sacra Polonorum trzeba powitać z radością. Inicjatywa publikowania średniowiecznych ksiąg liturgicznych związanych z dziejami naszego kraju udostępnia tę ważną grupę źródeł nie tylko badaczom historii Kościoła czy liturgii, ale także historii kultury średniowiecznej. Wykorzystywanie w badaniach nad dziejami mentalności czy obyczajów tego rodzaju tekstów utrudnia nie tylko rozproszenie rękopisów, ale też konieczność współpracy ze specjalistami w dziedzinie liturgiki. Omawiane tu wydawnictwo zostało opracowane przez ks. Szymona Fedorowicza, doświadczonego badacza liturgii w kręgu średniowiecznej katedry krakowskiej, mającego już w dorobku publikację Kolektarza wawelskiego wraz z gruntownym opracowaniem (Monumenta Sacra Polonorum, t. 3, Kraków 2007) i Autora wielu artykułów z tego zakresu. 
Do edycji wybrano jeden z najcenniejszych polskich przedtrydenckich zabytków liturgicznych. Znaczenie pontyfikału Erazma Ciołka wynika nie tylko z faktu, że kodyfikował on liturgię w katedrze płockiej w początkach XVI w., ale też ze względu na rolę, jaką odgrywał jego właściciel jako dworzanin Aleksandra Jagiellończyka, dyplomata, intelektualista, mecenas sztuki i duchowny. Tę wielość ról podejmowanych przez biskupa Ciołka odzwierciedla również charakter i zawartość pontyfikału: jego luksusowe wykonanie i ozdobienie 62 miniaturami, przedstawiającymi m.in. ryty dopełniane przez biskupa, w tym obrzędy koronacyjne, a także zapis porządku koronacyjnego króla i królowej. Te cechy omawianego zabytku sprawiają, że budzi on zainteresowanie historyków badających ideologię i rytuały władzy, a także historyków sztuki.

Pontyfikał Erazma Ciołka jest blisko spokrewniony z trzema XV-wiecznymi pontyfikałami krakowskimi sporządzonymi dla Zbigniewa Oleśnickiego, Tomasza Strzępińskiego i Fryderyka Jagiellończyka oraz ze spisanym w końcu XIV w. pontyfikałem arcybiskupów lwowskich, chociaż nie wiadomo, czy używanym we Lwowie już w średniowieczu. Księga obrzędów biskupa Erazma, niewątpliwie spisana w Krakowie krótko po 1503 r. (nominacja Ciołka na biskupstwo płockie), jest więc ostatnim ogniwem z tego szeregu. W księgach tych powtarza się brzmienie wielu formuł liturgicznych, chociaż niekiedy występują różnice w ich kolejności, a niektórych formuł brakuje w poszczególnych pontyfikałach. Dlatego warto może wyrazić żal, że edycja nie objęła wszystkich czterech ksiąg przy uwzględnieniu odmianek tekstowych. Takie zestawienie tekstu wszystkich czterech zabytków być może pokazałoby w sposób przejrzysty ich wzajemne związki oraz zachodzące między nimi różnice i niewykluczone, że pozwoliłoby na prześledzenie ewolucji, jaka dokonywała się w trakcie kopiowania kolejnych pontyfikałów. Obawiać się też można, że po opublikowaniu pontyfikału Erazma Ciołka nieprędko doczekamy się wydania jego trzech krakowskich poprzedników, gdyż wobec udostępnienia drukiem tekstu zawartych w nim rytów potrzeba edycji niemal identycznie brzmiących tekstów może wydać się mniej pilna. Oczywiście postulowane przeze mnie takie wydanie zbiorcze wszystkich czterech pontyfikałów byłoby przedsięwzięciem znacznie bardziej pracochłonnym niż publikacja samego pontyfikału Ciołka. Należy się więc cieszyć, że przynajmniej ten ostatni został udostępniony drukiem i postulować rychłe podjęcie prac nad edycją wcześniejszych ksiąg.

Pontyfikał Ciołka z racji swojego znaczenia był już przedmiotem wielu publikacji naukowych. Samemu Ciołkowi poświęcono dwie monografie (autorstwa ks. Henryka Folwarskiego i Ałły Brzozowskiej), pontyfikały krakowskie omówił obszernie ks. Zdzisław Obertyński, dekorację malarską kodeksu - Barbara Miodońska, ordo koronacyjne zaś - Zbigniew Dalewski. Ten zadowalający stan badań sprawił, że wystarczyło w prezentowanej edycji dać dość zwięzłe opracowanie edytorskie, ograniczone do najbardziej niezbędnych informacji. Należy mieć nadzieję, że po postulowanej przeze mnie publikacji wszystkich czterech pontyfikałów przyjdzie czas na obszerną monografię tych zabytków i ich roli w liturgii Kościoła krakowskiego oraz płockiego.

Edycji tekstu dokonano według zasad ustalonych przez Kassiusa Hallingera dla późnośredniowiecznych rękopisów liturgicznych. Zasady te zastosował Wydawca już wcześniej, przy publikacji Kolektarza wawelskiego. Zgodnie z tymi zasadami poprawiono pisownię łacińską wyrazów, które w średniowieczu zapisywane były niejednolicie, także w jednym tekście, o czym zresztą Wydawca informuje w zrozumiały sposób we wstępie. Oczywiste błędy, opustki czy skreślenia i poprawki dokonane względem oryginału są sygnalizowane w przypisach tekstowych. Aparat uzupełniają przypisy rzeczowe identyfikujące cytaty z Pisma Świętego zawarte w tekście oraz przypisy informujące o towarzyszącej danemu fragmentowi miniaturze. Odczyt tekstu nie budzi wątpliwości, chociaż pozwolę sobie zasygnalizować błędną lekcję „Domine Deus omnipotens, ut qui murmur nisam [podkr. M.S.] populi compesceres” (s. 238) zamiast „Domine Deus omnipotens, ut qui murmur insani [podkr. M.S.] populi compesceres" (BCzart., rkps sygn. 1212, mf. w BN, sygn. 16083, k. 232v).

Cennym uzupełnieniem publikacji są dobrej jakości kolorowe reprodukcje wszystkich miniatur i inicjałów zdobiących rękopis oraz przykładowych inicjałów niefiguralnych. Dzięki temu prezentację kodeksu umożliwiającą poznanie zarówno tekstu pontyfikału, jak i towarzyszących mu iluminacji, zawierających także istotne komunikaty, można uznać za kompletną.

Edycja pontyfikału Erazma Ciołka stanowi ważny etap w udostępnianiu ksiąg liturgicznych do badań nad kulturą Polski późnego średniowiecza i będzie z pewnością ważną inspiracją dla dalszych badań oraz, miejmy nadzieję, także kolejnych publikacji.

$$
\begin{array}{r}
\text { Maria Starnawska } \\
\text { Instytut Historii } \\
\text { Uniwersytet Przyrodniczo-Humanistyczny }
\end{array}
$$

Siedlce

Gdańska kronika Bernta Stegmanna (1528), koment. i wyd. Julia Możdżeń, współpr. Kristina Stöbener, Marcin Sumowski, Fontes, t. 117, Towarzystwo Naukowe w Toruniu, wyd. 2 popr. i uzup., Toruń 2019, ss. CXLV + 371, il. kol. 21

Kronika kupca gdańskiego Bernta Stegmanna, spisana ok. 1528 r. w języku wschodnio-średnio-niemieckim (Ostmitteldeutsch), należy do gatunku kronik uniwersalnych. Jej autor przedstawił historię Gdańska i Prus na tle szerokiej panoramy chrześcijańskich dziejów powszechnych. Późnośredniowieczny i nowożytny Gdańsk stanowił znaczący ośrodek miejskiego dziejopisarstwa, a dzieło Stegmanna jest najstarszym zabytkiem gdańskiej historiografii miejskiej zachowanym w autografie. Rękopis Stegmanna, przechowywany w Bibliotece Gdańskiej Polskiej Akademii Nauk (sygn. MS 1265), powstał jako czystopis. Jest to stosunkowo niewielkich rozmiarów kodeks $(210$ x $160 \mathrm{~mm})$, oprawiony prowizorycznie przez samego Stegmanna w brązową koźlęcą skórę. 
Ze względu na kompilacyjny charakter omawianej kroniki dzieło to do niedawna było traktowane przez badaczy przede wszystkim jako punkt wyjścia do studiów nad starszymi, niezachowanymi w oryginalnej postaci utworami historiograficznymi, które wykorzystał Bernt Stegmann. W tomach czwartym i piątym wydawnictwa Scriptores rerum Prussicarum (1870, 1874) Theodor Hirsch wydał nawet kilka fragmentów kroniki Stegmanna jako odrębne, nigdy nieistniejące w takiej formie teksty historiograficzne. Dopiero od mniej więcej 15 lat, również dzięki wnikliwym studiom Autorki recenzowanej edycji, Julii Możdżeń, kronika Stegmanna jest traktowana jako autonomiczne dzieło kronikarskie.

Recenzowaną edycję otwiera Przedmowa (s. VII-X) i obszerny, erudycyjny Wstęp (s. VII-LXI), które zostały wydane również w niemieckiej wersji językowej (s. LXIII-LXVII i LXIX-CXXIV). Dalej następuje wykaz skrótów oraz bibliografia źródeł i literatury przedmiotu (s. CXXV-CXLV). Po bibliografii zamieszczono edycję tekstu kroniki Bernta Stegmanna (s. 1-306). Wydawnictwo uzupełniają cztery załączniki źródłowe (s. 307-311) oraz spis 21 ilustracji (s. 329-331). Załączniki i ilustracje, zaopatrzone w polskie i niemieckie podpisy, odnoszą się do zagadnień poruszonych we Wstępie. Na końcu książki znajduje się indeks nazw geograficznych i etnicznych (s. 333-347) oraz indeks osobowy (s. 349-371). Biorąc pod uwagę zainteresowanie niemieckich badaczy dziejami Gdańska i Prus, pomysł przetłumaczenia fragmentów książki na język niemiecki trzeba ocenić jako w pełni uzasadniony. Warto jednak zauważyć, że przypisy i indeksy sporządzono jedynie po polsku.

We Wstępie do recenzowanej edycji J. Możdżeń nie ogranicza się do zestawienia dotychczasowych ustaleń historiografii dotyczących Bernta Stegmanna i jego kroniki, lecz także poddaje je uzasadnionej krytyce, formułując szczegółowe obserwacje i interpretacje. W pierwszym rozdziale Wstępu przybliża wiedzę o życiorysie Stegmanna, omawia główne cechy kroniki i rozpatruje możliwe przyczyny jej spisania. Wydawczyni podkreśla przede wszystkim dydaktyczną wymowę dzieła (s. XIX). Wyróżnia także dwa wątki przewodnie narracji kronikarskiej (s. XIX n.) - dążenie do udowodnienia słuszności działań Związku Pruskiego oraz wskazanie dobrych i złych przykładów rządzenia Gdańskiem. Zdaniem J. Możdżeń brak wzmianek o tematyce prywatnej i kommemoratywnej pozwala wykluczyć możliwość spisania kroniki dla rodziny autora. Uważa ona, że dzieło Stegmanna powstało raczej jako „materiał dydaktyczny (wychowawczy)” (s. XIX). Ponieważ w połowie XVI w. zachowany obecnie rękopis kroniki znajdował się w posiadaniu gdańskiej rodziny kupieckiej Kremerów, Wydawczyni domniemywa (s. XXIII-XXV), że Stegmann sporządził go jako pomoc w kształceniu urodzonego w 1516 r. Johanna Kremera. W następnym rozdziale Wstępu J. Możdżeń dokonuje pouczającej krytyki wysiłków edytorskich Th. Hirscha. Wyniki rozważań zilustrowano w tabeli, w której zestawiono poszczególne partie kroniki Stegmanna z ich XIX-wiecznymi edycjami. W trzecim rozdziale Wydawczyni przedstawia bazę źródeł spożytkowanych w kronice Stegmanna. Opowiada się za obowiązującym w dotychczasowej historiografii poglądem, zgodnie z którym głównym źródłem Stegmanna był jeden z rękopisów tzw. księgi Ferbera, czyli niezachowanej do dzisiejszych czasów w oryginale kroniki, spisanej zapewne w środowisku kancelarii Głównego Miasta Gdańska, a ukończonej około przełomu XV i XVI w. J. Możdżeń rozpatruje jednak również szczegółowo zagadnienie proweniencji wiadomości wprowadzonych do tytułowej kroniki z innych źródeł. W czwartym rozdziale omawia budowę kodeksu Stegmanna, a w piątym przedstawia zainteresowanie kroniką od połowy XVI w., kiedy została wzmiankowana po raz pierwszy, aż do przełomu XIX i XX w. J. Możdżeń stawia tezę (s. LII), że o upowszechnieniu znajomości kroniki Stegmanna zadecydowała głównie jej recepcja w środowisku kancelaryjnym i urzędniczym miasta Gdańska w drugiej połowie XVI w. Ostatni rozdział Wstęp dotyczy warsztatu pisarskiego Bernta Stegmanna oraz zasad edytorskich stosowanych podczas przygotowywania edycji jego kroniki.

Sposób opracowania edycji nie wzbudza zastrzeżeń. Wykorzystano projekt instrukcji wydawniczej Adama Wolffa oraz zalecenia Matthiasa Thumsera i Dietera Heckmanna dla wydawców źródeł niemieckojęzycznych. Zgodnie z deklaracją wyłożoną we Wstępie (s. LVII), Wydawczyni dążyła do możliwie najwierniejszego odwzorowania pisowni Bernta Stegmanna. Nie ujednolicono więc zapisu poszczególnych liter i na ogół nie normalizowano zapisu nazw własnych, zmodernizowano natomiast interpunkcję oraz zasady pisowni łącznej i rozłącznej. Rozwiązano również skróty stosowane przez Stegmanna. Tekst źródłowy został zaopatrzony w paginację nadaną kronice prawdopodobnie około połowy XVI w. przez jednego z jej pierwszych czytelników, mieszczanina i kronikarza gdańskiego Stenzla Bornbacha. Przypisy rzeczowe ograniczono do niezbędnego minimum.

Mimo ogólnie entuzjastycznej oceny recenzowanej pracy niektóre obserwacje zawarte we Wstępie wzbudzają wątpliwości. Przede wszystkim wydaje się, że odważna hipoteza, wedle której kronika Bernta Stegmanna powstała jako kompendium historyczno-dydaktyczne dla dwunastoletniego Johanna Kremera nie została wsparta wystarczająco mocnymi argumentami. Może w dalszych badaniach nad funkcjami kroniki Stegmanna warto byłoby sięgnąć po materiał porównawczy. Zastrzeżenia wzbudza też brak precyzji terminologicznej, przejawiający się w naprzemiennym stosowaniu w odniesieniu do dzieła Stegmanna terminów „kronika” i „kompilacja”. Poważniejszy sprzeciw wywołuje, na szczęście wyrażona tylko w Przedmowie (s. VIII), propozycja zaliczenia omawianej kroniki ,do typu piśmiennictwa pragmatycznego, mającego służyć jako podręczne źródło wiedzy i pouczeń”. W polskiej i europejskiej historiografii termin „piśmienność pragmatyczna” ma jasno określone pole semantyczne. Stosuje się go przeważnie w badaniach nad świecką piśmiennością urzędową oraz prywatną piśmiennością zawodową, m.in. rachunkową. Posłużenie się nim w odniesieniu do kroniki Stegmanna nie jest uzasadnione.

Sygnalizowane powyżej nieścisłości czy niedociągnięcia nie obniżają zasadniczo wysokiego poziomu merytorycznego recenzowanej książki. Nie może bowiem ulegać najmniejszej wątpliwości, że otrzymaliśmy solidną edycję bardzo istotnego źródła historycznego.

Piotr Okniński 


\section{Jakub Niedźwiedź, Poeta i mapa. Jan Kochanowski a kartografia XVI wieku, Terminus. Bibliotheca Classica. Seria 2, t. 7, Wydawnictwo Uniwersytetu Jagiellońskiego, Kraków 2019, ss. 335, il. 84}

W swej najnowszej książce Jakub Niedźwiedź stawia pytania o to, w jaki sposób rozwój kartografii w XVI w. wpłynął na twórczość najwybitniejszego poety polskiego renesansu, na jego postrzeganie i opisywanie przestrzeni, ale też na wynikający z tej zależności (przynajmniej w przypadku niektórych dzieł) projekt lektury. W pracy można dostrzec zarówno dobre - o ile może to ocenić historyk literatury - rozeznanie w zakresie dziejów średniowiecznej oraz renesansowej kartografii, jak i spory entuzjazm wobec przyjętych założeń. Badane zagadnienia łączyć należy przede wszystkim z konsekwencjami tzw. zwrotu przestrzennego w humanistyce, którego skutkiem jest zainteresowanie wzajemnymi relacjami literatury i kartografii (w tym zastosowaniem metod interpretacji literatury do odczytywania map), celami reprezentacji przestrzeni geograficznej w tekstach za pomocą symbolicznego mapowania, sposobami konstruowania przez pisarzy map fikcjonalnych terytoriów itp. W analizie funkcji dawnej kartografii i poezji oraz ich powiązań nie stroni Autor również od kategorii retorycznych i komunikacyjnych czy pojęć właściwych dla opisu dyskursu kolonialnego, stanowiących istotny składnik omawianej orientacji naukowej. Od razu pozwolę sobie stwierdzić, że zastosowanie takich właśnie procedur wobec poezji staropolskiej jest przedsięwzięciem prekursorskim i zdaje się służyć testowaniu metody, jej adekwatności i efektywności w odniesieniu do tekstów dawnych.

Książka składa się z pięciu głównych rozdziałów, poprzedzonych wprowadzeniem i podsumowaniem, a także ujętych ramą kompozycyjną w postaci zagajenia i zakończenia, mających formę fikcjonalnego dialogu Piotra Wolskiego i Jana Zamoyskiego (prolog) oraz apokryficznego listu biskupa płockiego do kanclerza (epilog), które dają wgląd w autorską wizję znaczenia i funkcjonowania map w kulturze XVI w. Zamiarem zasadniczej części studium jest próba dowiedzenia, że niektóre utwory Jana z Czarnolasu powstały (lub powstać mogły) w wyniku posługiwania się przez twórcę mapami bądź przyrządami astronomicznymi. W rozdziale I (Koordynaty: fraszka III 37 „Do snu” i „Phaenomena”) Autor przekonuje, że Kochanowski, komponując badane utwory, nawiązywał do fizycznych przedstawień nieba (astrolabium sferycznego, map nieba) oraz średniowiecznych map świata (nie tyle dających wyobrażenie o wiedzy geograficznej, ile służących głównie teologii). W kolejnym (Południe: elegia II 1) dowodzi, że poeta zachwalając młodemu Janowi Tęczyńskiemu korzyści podróży do Włoch, wzorował się na chorografii Italii z Bellum civile Lukana, lecz występujący w pierwowzorze katalog rzek uporządkował zgodnie z XVI-wiecznymi mapami półwyspu. Rozdział III (Europa: pieśń 24 „Ksiag wtórych”) zawiera porównanie geograficznych horyzontów sławy poetyckiej zarysowanych w odzie II 20 Horacego i w pieśni czarnoleskiej stanowiącej parafrazę rzymskiego utworu. W rozdziale IV (Pótnoc) poddano analizie trzy utwory: elegię III 1, Pamiatkę Janowi Baptyście hrabi na Tęczynie oraz Jezdę do Moskwy, które zdaniem Badacza są świadectwem szczególnego zainteresowania poety topografią Północy (krajów nadbałtyckich i państwa moskiewskiego), co J. Niedźwiedź uważa za konsekwencję publikacji pierwszych map tych regionów, ale również programowego „septemtrionalizmu” poety. Ostatnia, najobszerniejsza i zdaniem piszącego te słowa najlepiej dopracowana część pracy: Wojna i propaganda: „Atlas Księstwa Połockiego” i „,Oda o zdobyciu Połocka”, przedstawia propagandowe zadania publikacji atlasu Stanisława Pachołowieckiego, utworów Kochanowskiego czy innych pism dotyczących wojen batoriańskich. Były one częścią kampanii informacyjno-perswazyjnej prowadzonej przez kancelarię królewską, pozostającą wówczas pod kierownictwem Zamoyskiego, humanisty o europejskich horyzontach, a zarazem sprawnego propagandysty.

Publikację J. Niedźwiedzia uważam przede wszystkim za pracę otwierającą nowe horyzonty badawcze dla literaturoznawstwa staropolskiego, nie ma więc powodu, by dokonywać jej szczegółowego rozbioru krytycznego. Traktując ją jako interesującą propozycję, sądzę jednak, że poszerzenie pola obserwacji o piśmiennictwo średniowieczne, odrodzeniowe kompendia geograficzno-historyczne, poezję nowołacińską (choćby hodoeporikony i epinikiony) czy również twórczość wernakularną powstającą za życia, a także po śmierci Kochanowskiego, pozwoliłoby lepiej uchwycić zachodzące w renesansie zmiany świadomości geograficznej i sposoby mapowania realnej rzeczywistości przez ówczesnych pisarzy. Nie chodzi oczywiście tylko o wiedzę krajoznawczą, lecz o semantykę tekstów literackich, ich przekaz ideowy oraz określenie antropologicznych konsekwencji poruszania się ludzi w przestrzeni. Recenzowana książka prezentuje tę problematykę fragmentarycznie, dopominając się o ujęcie uwzględniające dłuższy przedział czasu, gdyż przywołane w rozprawie utwory Kochanowskiego nie wydają się wystarczająco miarodajne. Rozważając natomiast konkretne koncepcje Badacza, pozwolę sobie podzielić się jedynie kilkoma zastrzeżeniami, które wymagałyby moim zdaniem jeszcze namysłu ze względu na wagę wniosków, do jakich dochodzi Autor, interpretując wybrane utwory.

Widnokrąg ogarniany spojrzeniem przez poetę-łabędzia w pieśni Niezwyklym i nie leda piórem opatrzony (II 24) uznał Badacz za efekt kontrmapowania, zabiegu zwróconego „przeciw, opartym na wiedzy starożytnej, szesnastowiecznym praktykom mapowania wykluczającym Polskę z mapy”, traktując wiersz Kochanowskiego jako „radykalną polemikę z wierszem poety rzymskiego i jego europejską recepcją” (s. 101), dostrzegając w nim nawet zamiar przesunięcia „,centrum z Rzymu do Rzeczypospolitej” (s. 116), która „staje się depozytariuszem wiedzy, miejscem jej wytwarzania lub nabywania” (s. 127). Nie mogę przystać na te wnioski. Zarówno pieśń Horacego, jak i Kochanowskiego to przede wszystkim wypowiedzi autotematyczne, zarysowujące horyzonty nieśmiertelnej sławy obu autorów. W moim przekonaniu polski twórca w naśladowaniu rzymskiej ody nie tyle polemizuje ze swym mistrzem, ile składa mu hołd, dając do zrozumienia, że stworzył w poezji polskiej zbiór, który zapewni mu podobną sławę i który stanowi zarazem programowe nawiązanie do antycznego wzorca (horacjański charakter zbioru jest dobrze rozpoznany przez historyków literatury). Nadworny poeta Oktawiana Augusta zarysował horyzonty przestrzenne swojej nieśmiertelności, stąd dla niego centrum pozostawał Rzym, natomiast Kochanowski zmienił perspektywę na własną, więc siłą rzeczy jego centrum była Polska, choć zmianie tej towarzyszy też aktualizacja (nie metonomazja - jak 
twierdzi Autor recenzowanej książki na s. 114 n. - bo przecież Tatarów nazywa Tatarami, nie Scytami), zatem granice cywilizowanego świata musiały się zmienić.

Z kolei interpretując Jezdę do Moskwy jako poemat kartograficzny, przekonuje krakowski literaturoznawca, że ,integralnym elementem lektury poematu powinna być równoległa lektura mapy” (s. 148 n.), gdyż „bez jej kontekstu lektura drugiej części utworu jest niepełna, niepełne jest także zrozumienie tekstu" (s. 160). Autor przypuszcza też, że Jan z Czarnolasu układając epinikion ku czci Krzysztofa Radziwiłła, „dysponował wariantem tej samej [rękopiśmiennej, powstałej na potrzeby wojskowe - R.K.] mapy, która posłużyła kartografowi Gerardowi Merkatorowi do sporządzenia mapy Russiae pars amplificata" (s. 156). Nie negując zarówno tego, że Kochanowski mógł dysponować mapą przedstawiającą zasięg dywersyjnej wyprawy „Pioruna”, jak i tego, że mapa pomaga lepiej zorientować się w przebiegu trasy, powątpiewam jednak w projektowanie przez piewców śmiałego zagonu (bo pod uwagę należy wziąć także utwory Franciszka Gradowskiego i Andrzeja Rymszy) lektury z mapą. Zauważyć bowiem należy, iż żaden z nich nie zaopatrzył swej publikacji w mapę, poprzestając na wyliczeniu toponimów, a do rękopiśmiennych map operacyjnych dostęp mieli wszak nieliczni. Gdyby przyjąć sugestie J. Niedźwiedzia, trzeba by posądzać tych pisarzy o złośliwość wobec własnych odbiorców, którym udostępniono utwory bez koniecznego do ich zrozumienia dodatku. Nie można ponadto lekceważyć praktyki sporządzania diariuszy wojennych, skwapliwie wykorzystywanych przez ówczesnych panegirystów. Dziennik taki prowadził najprawdopodobniej uczestnik wyprawy Andrzej Rymsza, z którego Deketeros akroama (utwór ukończony w 1582, opublikowany w 1585 r.) Jezda do Moskwy wykazuje sporo podobieństw w warstwie informacyjnej (Kochanowski łączy z toponimami te same co Rymsza zdarzenia, czego z samej mapy wyczytać z pewnością nie mógł). Pominięcie tej kwestii w omówieniu genezy poematu Kochanowskiego uważam za poważne niedopatrzenie.

W erudycyjnym rozdziale zamykającym książkę włączenie się przez Kochanowskiego w antymoskiewską akcję propagandową prowadzoną przez Zamoyskiego dowodzić ma, że poeta nie zerwał definitywnie związków z dworem. Autor rozprawy przekonuje, że w odach ułożonych po zdobyciu Połocka pojawiają się informacje świadczące o tym, że poeta „miał wgląd w sprawy kancelarii królewskiej” (s. 224 n.). Koronny dowód stanowią zdaniem Badacza nawiązania do przechwałek i pogróżek Iwana Groźnego słanych do Batorego, o których informowały pisma prokurowane przez kancelarię. Obawiam się, że Autor książki nie docenił obiegu informacji ustnej. Pamiętać też należy, że car słał podobne listy już w 1563 r. po zdobyciu Połocka, o czym Kochanowski wspomina w Satyrze albo Dzikim mężu (w. 83-84), zatem taktyka zastraszania stosowana przez samodzierżcę była mu dobrze znana już wcześniej. Także dobór epitetów kreujących Iwana na tyrana nie wymagał lektury ani kroniki Aleksandra Gwagnina, ani innych pism (s. 207 n.), gdyż masakrowanie z jego rozkazu ludności cywilnej po pacyfikacji Nowogrodu i Pskowa oraz w trakcie wojen inflanckich czy też skandaliczne potraktowanie członków poselstwa polskiego do Moskwy przez opryczników w 1570 r. były wszak szeroko komentowane przez opinię publiczną. Stwierdzenia formułowane w rozdziale wymagałyby zatem jeszcze zastanowienia.

Mimo zastrzeżeń wobec niektórych tez stawianych w książce, uważam ją - pozwolę sobie powtórzyć w konkluzji wcześniejszą uwagę - za publikację ważną, stanowiącą cenną propozycję badawczą, wartą z pewnością kontynuacji w dalszych, szerzej zakrojonych studiach.

Roman Krzywy

Uniwersytet Warszawski

Lustracja cel $\boldsymbol{i}$ myt matopolskich z 1565 roku, wyd. Bożenna Wyrozumska, współpr. Marcin Starzyński, indeksy oprac. Patrycja Wiencierz, Polska Akademia Umiejętności, Kraków 2019, ss. XV + 138, il. 2

Tematyka dotycząca funkcjonowania dróg w dawnej Polsce jest podejmowana w historiografii dość rzadko. Sporadycznie także wydawane są źródła poświęcone temu problemowi. Do nielicznych badaczy zajmujących się staropolskimi drogami należy bez wątpienia Bożenna Wyrozumska, Autorka cennej monografii Drogi w ziemi krakowskiej do końca XVI wieku (Wrocław-Kraków 1977) oraz wartościowej edycji źródłowej Lustracja dróg województwa krakowskiego z roku 1570 (Wrocław-Kraków 1971), do której wstęp historyczny napisał Karol Buczek (opracował on również skorowidz rzeczowy). Z zainteresowaniem wypada więc przyjąć ukazanie się kolejnego wydawnictwa przygotowanego przez B. Wyrozumską, zatytułowanego Lustracja cet $i$ myt matopolskich z 1565 roku. W pracy nad edycją wspomagali ją Marcin Starzyński oraz Patrycja Wiencierz, Autorka indeksów. Wydawnictwo to dotyczy pierwszej rewizji dróg, przeprowadzonej równocześnie z lustracją dóbr królewskich na fali tzw. ruchu egzekucyjnego, którego apogeum przypada na okres panowania króla Zygmunta II Augusta. Podstawą edycji był oryginalny rękopis znajdujący się obecnie w Archiwum Narodowym w Krakowie, w zespole Archiwum Sanguszków pod sygn. 19, s. 199-369 [dalej: AS 19]. Przekaz ten, starannie i czytelnie sporządzony, jak też dość dobrze zachowany, stanowi jedno z najcenniejszych, wręcz unikatowych, źródeł dotyczących myt i dróg polskich w XVI w.

Omawiana publikacja, poza właściwym tekstem źródła, składa się z przedmowy pióra B. Wyrozumskiej, uzupełniającego ją opisu kodykologicznego rękopisu AS 19 sporządzonego przez M. Starzyńskiego, aneksu zawierającego, odnalezioną niegdyś przez K. Buczka, lustrację ceł i myt na Rusi Czerwonej i Podolu z 1565 r., wykazu dokumentów wymienionych w rękopisie oraz indeksów osobowego i geograficznego. Dodano również dwa zdjęcia okładek kodeksu mieszczącego źródło. 
Przedmowa, jak zaznacza sama Autorka, nawiązuje do Wstępu historycznego K. Buczka poprzedzającego wspomnianą wyżej Lustrację dróg województwa krakowskiego z roku 1570, dzięki czemu można było teraz do niezbędnego minimum ograniczyć omawianie genezy oraz tła rewizji dróg i myt. B. Wyrozumska wyjaśnia także powody, dla których nie wydała niegdyś obu tekstów (z 1565 i 1570 r.) łącznie, choć wskazuje, że taki był jej pierwotny zamiar¹. Obecna edycja jest realizacją dawnych planów. Oparto ją na Instrukcji wydawniczej dla źródet historycznych od XVI do połowy XIX wieku².

Edytorka podkreśla, że nie wiadomo, jak rękopis znalazł się w posiadaniu Sanguszków, ale po części przedstawia jego dalsze losy. Nie wskazuje natomiast oryginalnego tytułu rękopisu AS 19, który początkowo brzmiał: Myta $i$ cta na wodzie, jako promy, mosty, a na ziemi, jako groble, gaci, burki i naprawowanie dróg miastom i pewnem osobom albo civitatibus vel collegiis nadane. Później słowo jako zostało przekreślone i nadpisano nad nim to jest, w efekcie tytuł został nieco przekształcony: Myta i cla na wodzie to jest promy, mosty, a na ziemi to jest groble, gaci, burki i naprawowanie dróg miastom i pewnem osobom albo civitatibus vel collegiis nadane. Taki zapis pojawia się w recenzowanej edycji tylko raz (s. 3 ), ale bez oznaczenia wykreśleń i nadpisań. Na poprzedzającej tekst źródłowy karcie (s. 1) widnieje natomiast wpisany w nawias kwadratowy tytuł nadany wydawnictwu przez B. Wyrozumską, tj. Lustracja cel i myt małopolskich z 1565 roku. Oryginalny tytuł, bez odnotowania poprawek (skreśleń i nadpisań), został podany w przywoływanym wstępie K. Buczka ${ }^{3}$. Tam też znajduje się informacja o miejscu przechowywania rękopisu zaprezentowanego w aneksie ${ }^{4}$, całkowicie pominięta w omawianej tutaj publikacji. Obecnie można ją doprecyzować, wskazując aktualne oznaczenia archiwalne, tj. AGAD, tzw. Metryka Litewska, seria 6. Księgi rewizji i opisów (Dział IV B), sygn. 7, s. 746-764.

Tekst głównego źródła edycji, tj. AS 19, został poprawnie odczytany i oddany. Zdarzają się jednak błędy i pomyłki. Na przykład na s. 11 [s. 218$]$ brak wskazania omyłkowo powtórzonego i następnie skreślonego wyrazu percipare, podobnie na s. 30 [s. 256] potraktowano słowa do tegoż. Z kolei na s. 62 [s. 327] zaznaczono wykreślenie: To pysaz., choć powinno być raczej: tu pysarz, a poza tym są jeszcze przekreślone przynajmniej trzy słowa, choć obecnie nieczytelne. Nie oznaczono też fragmentu na s. 5 [s. 203 n.] pisanego w oryginale wyraźnie mniejszym rozmiarem pisma. Można również dyskutować nad poprawnością modernizacji w kilku miejscach, np. zapisaniem określenia zjachat jako zjechat (s. 30 [s. 257]).

W mojej ocenie największym mankamentem edycji jest brak przypisów rzeczowych (zamieszczono jedynie tekstowe, zresztą niezbyt liczne), przewidywanych w instrukcji wydawniczej i - co ciekawe - zastosowanych w wydanej przez B. Wyrozumską pokrewnej, wcześniejszej edycji Lustracja dróg województwa krakowskiego z roku $1570^{5}$. Braku tego nie rekompensuje, a jeśli już to tylko częściowo, sygnalizowane w przedmowie (s. X) przeniesienie objaśnień osób i miejscowości do indeksów (co utrudnia lekturę). Ponadto nie przewidziano indeksu rzeczowego, a jedynie nazw osobowych i geograficznych, przy czym nie są one odpowiednio rozbudowane, dlatego nie mogą w pełni objaśniać tekstu źródła. Informacje o osobach w indeksie są enigmatyczne, a przez to nie zawsze precyzyjne. Postacie są jedynie identyfikowane, przez co czytelnik otrzymuje o nich minimalne i bardzo niepełne informacje. Przykładem mogą być chociażby dwaj wymienieni w tekście i indeksie Decjusze, noszący te same imiona Ludwik Jost (s. 4 n., 120), przy czym jeden w źródle jest nazywany karbarzem wielickim, a w indeksie widnieje bez tej funkcji. Z kolei Anzelm Gostomski został w tekście na s. 44 [s. 289] wymieniony jako kasztelan płocki, a w indeksie (s. 120) tylko z urzędem wojewody rawskiego, którym został dopiero w 1572 r. Podobnych przypadków jest więcej. Do tego w indeksie nie uwzględniono wielu osób pojawiających się w źródle tylko z tytułem lub funkcją (te ostatnie nie zostały w indeksach ujęte). Nie ustalano ich personaliów. Na przykład na s. 5 i 6 [s. 204 i 205] jest wzmiankowany opat tyniecki, ale nigdzie nie znajdziemy informacji, że był nim wówczas Jan Łowczowskí. Na s. 8 [s. 212] wymieniono wojewodę krakowskiego, ale bez sprecyzowania, że chodzi o Spytka Wawrzyńca Jordana - w efekcie w indeksie również go nie odnotowano. Pominięto także Zofię Ocieską z Marszowic, dysponentkę cła mostowego w Działoszycach, ponieważ rewizorzy wymienili ją jedynie jako „JMP kanclerzyną z Marszowic” (s. 28 [s. 250]). Nie zidentyfikowano i nie uwzględniono też Hieronima Modliszewskiego (Modliszowskiego) określonego w lustracji tylko tytułem starosty łomżyńskiego (s. 45 [s. 291]). Podobnie stało się z Andrzejem Gnojeńskim, czyli występującym na s. 34 [s. 266] starostą nowomiejskim7. Zdarzają się w indeksie osobowym przypadki niekompletnych haseł. Na przykład Paweł Korytko został odnotowany tylko jako szl., tj. szlachcic (s. 6 [s. 205], 121), i rzeczywiście w 1565 r. nie pełnił żadnych urzędów, ale później został kolejno podkomorzym przemyskim i lwowskim, by następnie awansować na kasztelanię przemyską ${ }^{8}$. Wymieniony na s. 6 [s. 217], a następnie w indeksie bez imienia (s. 120) jako posesor myta „na bieckim gościńcu” Gładysz to Stanisław właściciel Uścia, po którym przywilej objął syn Baltazar9. Jan Rzemieński (s. 34 [s. 266], 122) powinien zostać rozszyfrowany z bardziej znanym nazwiskiem -

\footnotetext{
${ }^{1}$ Przeszkodą było przede wszystkim przygotowanie jeszcze w 1966 r. wydania rękopisu AS 19 przez Zbigniewa Góralskiego, który zmarł w 1997 r., nie opublikowawszy edycji; zob. s. V recenzowanej pracy.

${ }^{2}$ Instrukcja wydawnicza dla źródet historycznych od XVI do połowy XIX wieku, red. K. Lepszy, Wrocław 1953; przedruk: J. Tandecki, K. Kopiński, Edytorstwo źródel historycznych, Warszawa 2014, s. 359-384.

${ }^{3}$ Lustracja dróg województwa krakowskiego z roku 1570, wyd. B. Wyrozumska, Wrocław-Kraków 1971, s. XII.

${ }^{4}$ Tamże, s. VIII, przyp. 16.

${ }^{5} \mathrm{~W}$ recenzowanym wydawnictwie pojawia się tylko jeden taki przypis - na s. 11, opatrzony nr. 1 .

${ }^{6}$ P. Sczaniecki, Katalog opatów tynieckich, Kraków 1978, s. 128-132.

7 W. Urban, Gnojeński Andrzej, w: PSB, t. 8, Wrocław 1960, s. 157.

${ }^{8}$ A. Boniecki, Poczet rodów w Wielkim Księstwie Litewskim w XV i XVI w., t. 11, Warszawa 1887, s. 205; UdR. Spisy, red. A. Gąsiorowski, t. 3 , z. 1: Urzędnicy województwa ruskiego XIV-XVIII wieku (ziemie halicka, lwowska, przemyska, sanocka). Spisy, oprac. K. Przyboś, Wrocław 1987, s. $133,202,222,350$

9 Lustracja dróg, s. 42; A. Boniecki, Poczet rodów, t. 6, s. 92.
} 
Jan Tarnowski z Rzemienia ${ }^{10}$. Rachwał Mychowski (s. 41 [s. 281], 122), to po prostu Rafał Michowski ${ }^{11}$. Także indeks nazw geograficznych nie jest na tyle rozwinięty, aby zastępować przypisy. Uwzględniono w nim wprawdzie miejscowości i rzeki, ale brak np. nazw ulic, bram miejskich, klasztorów, karczem itp., co zważywszy na charakter źródła jest istotną wadą. Poza jednym przypadkiem lasu Lęziny (Lezne) w województwie sandomierskim, dwukrotnie i bardzo wyraźnie wskazanego w źródle (s. 48 [s. 296], 62 [s. 326], 130), nie uwzględniono kompleksów leśnych, np. Bocysów (s. 33 [s. 265]), Ławy (s. 67 [s. 337 n.]). Zdarzają się też nieścisłości w identyfikacji. Na przykład wspomniany na s. 4 [s. 201] Prądnik (Promnyk) to raczej podkrakowska wieś, a nie rzeka o tej samej nazwie, za to widniejący na s. 10 i 11 [s. 215 i 217] Sądecz to, jak się wydaje, nie Stary (s. 135), ale Nowy Sącz. Zapewne przez niedopatrzenie pominięta została w indeksie wieś Boszczyn (Boszczynek) w powiecie proszowskim, gdzie pobierano myto na drodze prowadzącej z Bochni do Wielkopolski i na Mazowsze.

Powyższe uwagi nie oznaczają, że indeksy zostały zrobione źle, niewłaściwa jest natomiast ich koncepcja. Musiałyby być o wiele bardziej rozbudowane i drobiazgowe, aby rzetelnie zrekompensować brak przypisów rzeczowych. Rezygnacja z tych ostatnich była zdecydowanym błędem. Mimo to edycję lustracji ceł i myt małopolskich z 1565 r. należy ocenić pozytywnie. Wydane zostało cenne i rzadkie źródło, które do tej pory pozostawało w rękopisie i było znane tylko bardzo wąskiemu gronu badaczy.

\section{Marek Ferenc \\ Uniwersytet Jagielloński Kraków}

\section{Lustracja województwa podlaskiego 1602 roku, wyd. Michał Sierba, Wydaw- nictwo Naukowe Sub Lupa, Warszawa 2017, ss. XXX + 115}

Prawie sześć dziesięcioleci czekało środowisko badaczy epoki staropolskiej na następną naukową edycję lustracji królewszczyzn z terenu Podlasia. Dzieło uczonych okresu powojennego, Jerzego Topolskiego i Jerzego Wiśniewskiego, wydawców takowych źródeł z lat 1570 i 1576, podjął na nowo Michał Sierba. Wydanie publikacji było możliwe również dzięki wsparciu finansowemu ze strony władz samorządowych obecnego województwa podlaskiego w postaci rocznego stypendium (zob. s. IV, XXIII, XXVII). Wersja elektroniczna opracowania (format .pdf, plik przeszukiwalny) została udostępniona w Internecie stosunkowo niedługo po premierze, na początku stycznia 2018 r. ${ }^{1}$

Urodzony w 1987 r. Autor edycji należy do młodego pokolenia badaczy Podlasia. Jego zainteresowania naukowe koncentrują się wokół przedrozbiorowych dziejów dwóch miast dawnej ziemi bielskiej - Tykocina i Orli (wraz z przyległościami). Doktorat obronił w 2016 r. na Wydziale Filozoficzno-Historycznym Uniwersytetu Łódzkiego. Posiada znaczny dorobek naukowy, na który prócz recenzowanej pracy składają się monografia Radziwiłłowskie dobra Orla (1585-1695) (Białystok 2017), będąca publikacją rozprawy doktorskiej, oraz ponad 20 artykułów w czasopismach historycznych, w tym kilka edycji źródłowych.

O przydatności i wartości tego rodzaju materiału źródłowego nie trzeba zapewniać. Lustracja z początku XVII w. objęła wprawdzie stosunkowo niewielki obszar Podlasia, sprowadzający się tylko do ziemi bielskiej: trzy starostwa z ośmiu - knyszyńskie, goniądzkie i bielskie - oraz jedno z czterech leśnictw - knyszyńskie. Posesorka nie pozwoliła na zrewidowanie dzierżawy pokaniewskiej położonej w granicach ziemi mielnickiej. Poza oczywistymi walorami dla poznania historii gospodarczej i dziejów osadnictwa źródło - na co zwrócił uwagę Wydawca - zawiera pierwszorzędny materiał do badań językowych. W edycji znajduje się też szereg pomniejszych wzmianek źródłowych, które można wykorzystać przy wielu projektach badawczych. Można wskazać chociażby elementy przydatne dla badaczy staropolskiej wojskowości, a konkretnie formacji piechoty wybranieckiej i pospolitego ruszenia. W jednym z rewidowanych starostw - bielskim - możemy ponadto zaobserwować spustoszenie, jakie tutaj własny stacjonujący ,żołnierz [...] tak w koniech, jako w inszych dobytkach [...] poczynił” (s. 66).

Omawiane wydawnictwo składa się zasadniczo z trzech części: wstępu, właściwej edycji źródłowej oraz indeksów: rzeczowego, osobowego i nazw geograficznych. Nie znajdziemy w nim osobnej bibliografii, mamy tu za to wykaz skrótów bibliograficznych oraz tych pozostawionych w tekście źródłowym. Innym elementem ułatwiającym korzystanie z edycji jest szczegółowy spis treści, który wiernie oddaje konstrukcję źródła.

Struktura publikacji wprost wynika z decyzji, zrozumiałej zresztą, o zastosowaniu się do wytycznych zawartych w instrukcji wydawniczej dla źródeł od XVI do połowy XIX w. autorstwa Kazimierza Lepszego oraz przygotowanej specjalnie na potrzeby edycji lustracji z XVI-XVIII w. przez Pracownię Edytorską Źródeł Historycznych Instytutu Historii Polskiej Akademii Nauk. W przestrzeganiu tych prawideł Wydawca poczynił jednak pewne istotne wyjątki. Zrezygnował mianowicie $\mathrm{z}$ wykazu dokumentów wzmiankowanych w tekście źródłowym i mapy ukazującej obszar objęty lustracją (zob. niżej), natomiast nazwy geograficzne oddał poprzez transliterację, nie zaś modernizowaną transkrypcję, co jest ukłonem w stronę językoznawców rozwiązaniem przejętym od J. Topolskiego i J. Wiśniewskiego (s. XXIV). Wszystkie te informacje zawarte zostały we wstępie,

${ }^{10}$ W. Dworzaczek, Hetman Jan Tarnowski. Z dziejów możnowładztwa małopolskiego, Warszawa 1985, s. 343-345.

11 S. Uruski, A. Kosiński, A. Włodarski, Rodzina. Herbarz szlachty polskiej, t. 10, Warszawa 1916, s. 376 n.

${ }^{1}$ Dane z Repozytorium Uniwersytetu Łódzkiego, <http://dspace.uni.lodz.pl:8080/xmlui/handle/11089/ 23845? show=full> [dostęp: 23.01.2020]. 
gdzie w sposób zwięzły, acz w zupełności wystarczający (co należy uznać za zaletę tej książki), Edytor przedstawił metodę wydania i podstawę źródłową. Zgodnie z przyjętym schematem wydawania staropolskich lustracji w części wstępnej znalazło się też miejsce na omówienie podstawy prawnej rewizji królewszczyzn z 1602 r., czasu i zakresu terytorialnego jej sporządzenia, modus operandi lustratorów oraz ich krótkie biogramy.

Część wstępna zasługuje na wysoką ocenę, przygotowana została w pełni profesjonalnie, a do tego napisana przystępnym językiem. Szkoda jedynie, że Edytor nie odniósł się do digitalizacji i udostępniania w Internecie źródeł historycznych w postaci skanów. Proces ten w ostatnich latach przyspiesza, przy czym można się spodziewać, że w niedalekiej przyszłości obejmie zachowane w Archiwum Skarbu Koronnego lustracje². Rewizja województwa podlaskiego z 1664 r. z Metryki Koronnej już jest dostępna online ${ }^{3}$. Wyrażenie przez Wydawcę swojego stosunku do tego zagadnienia - także w kontekście planów wydania kolejnych lustracji podlaskich (s. XI, przyp. 2) - mogłoby stać się interesującym głosem w dyskusji na temat współczesnego edytorstwa.

Tekst źródła został solidnie sczytany, a przyjęte zasady wydawnicze na ogół sumiennie zastosowane. Wyłowione podczas lektury omyłki i niekonsekwencje stanowią nieliczne wyjątki potwierdzające tę regułę, aczkolwiek należy zaznaczyć, że w niniejszej recenzji zrezygnowano z drobiazgowego konfrontowania każdego słowa z rękopisem, jak to czynili poprzednicy Bodaj tylko w jednym przypadku forma kończąca się na -ch nie została zmodernizowana na -ś, przez co pozostało ,a iżech my” zamiast „a iżeśmy” (s. 56). W innym miejscu winno być „tę trzyma”, nie zaś „te trzyma” (s. 47), gdyż brak tej ingerencji zmienia sens zdania. Należało również zmodernizować formę „mansionarze” na „mansjonarze” (s. 41). Przykładem błędnego odczytania sensu słowa jest wstawienie „włók przyrzeczonych” (s. 85, 95) zamiast „przerzeczonych” (w znaczeniu: wspomnianych wcześniej/wyżej). Chociaż jest to rzeczą dość oczywistą, wydaje się, że we wstępie i wykazie skrótów należało zaznaczyć dwoistość możliwego rozwiązania skrótu P. - Pan/Pani (zob. s. XXV, XXX). Brak tego sprawia, że zapis „P. Stołuczka” (s. 47) można odczytać tylko jako „Pan Stołuczka”, a w tym wypadku moim zdaniem mamy do czynienia raczej z formą żeńską niż z obocznością nazwiska.

Przypisy tekstowe są w znakomitej większości bez zarzutu. Najpoważniejsza omyłka przydarzyła się przy - emendowanej już w oryginale - nazwie miejscowości Potyczina (s. 52, przyp. a; s. 54, przyp. a). Wersje po poprawkach naniesionych w źródle powinny brzmieć „Potoczizna” i „Potocziznej”, nie zaś „Potyczizna” i „Potycziznej”.

Do mocnych stron omawianej publikacji należą przypisy rzeczowe, świadomie rozbudowane ponad wymogi instrukcji (zob. s. XXIV, przyp. 59). Wydawca nie szczędził trudu na szeroko zakrojoną, krajową i zagraniczną, kwerendę archiwalną w celu ustalenia personaliów osób wzmiankowanych w tekście. Wykorzystane zostały nie tylko pozostające w rękopisie lustracje (1616, 1664), ale także - a może przede wszystkim - księgi sądowe, zarówno w postaci oryginalnej, jak i wypisów Ignacego Kapicy. Efekt końcowy tych dociekań budzi szacunek. Względem tej części opracowania można poczynić jedynie kilka drobnych uwag. Otóż zestawienie ojca i syna - Jana Sariusza Zamoyskiego (s. 3, przyp. 2) i Tomasza Zamoyskiego (tamże, przyp. 3) może sugerować, że pierwszy ordynat miał drugie imię, gdy w rzeczywistości była to udostojniona, historyzująco-łacińska forma nazwiska używana przezeń w czasie zagranicznych studiów ${ }^{5}$. Daty panowania Zygmunta Augusta w Koronie i na Litwie to istotnie lata 1548-1572 (s. 4, przyp. 6), aczkolwiek należałoby chyba doprecyzować, że chodzi o rządy samodzielne, ponieważ, jak wiadomo, mieliśmy tu do czynienia z elekcją i koronacją vivente rege w latach 1529 (Wielkie Księstwo Litewskie) i 1530 (Królestwo Polskie). Co do rodziny Stołuckich (Stołuskich?), należy sprostować przypuszczenie Edytora, że „pochodzili najprawdopodobniej z bliżej niezidentyfikowanej wsi Stołuszcze w ziemi bielskiej” (s. 39, przyp. 82). W rzeczywistości wieś Stołuszcze-Rawa powstała właśnie na gruntach goniądzkich, będących wcześniej w posiadaniu tej rodziny. Jej śladem jest nazwa miejscowa Rawy występująca przy granicy obecnej wsi Wójtostwo z miastem Goniądz ${ }^{6}$. Bardziej prawdopodobnym może być trop knyszyński i skojarzenie Stołuckich ze Stołuskimi, choć wypada zauważyć, że XVI-wieczny pleban w Knyszynie i Kalinówce ks. Marcin dość często występuje w źródłach także jako Stoliski . Stoliscy wywodzili się ze Stołyżyna (dziś Stołężyn) w województwie kaliskim, jednak ród najprawdopodobniej wygasł w drugiej połowie XVI w. ${ }^{8}$ Natomiast Stołuccy vel Stołuscy występowali w województwie ruskim w pierwszej połowie XVII w., a jeden z nich był rotmistrzem piechoty

2 Zob. AGAD, Archiwum Skarbu Koronnego, <https://szukajwarchiwach.pl/1/7/0\#tabZespol> [dostęp: 25.01.2020].

${ }^{3}$ AGAD, MK, Lustracje, dz. XVIII, sygn. 64, <http://agadd.home.net.pl/metrykalia/4/7/sygn.\%2064/> [dostęp: 25.01.2020].

${ }^{4}$ Zob. W. Ochmański, rec.: Lustracje województwa podlaskiego 1570 i 1576, wyd. J. Topolski, J. Wiśniewski, Wrocław-Warszawa 1959, „Rocznik Białostocki", 1, 1961, s. 337-343

${ }^{5}$ Zob. P. Popiel, Jan Zamoyski w Padwie i Wenecyi, Kraków 1876, s. 30; Archiwum Jana Zamoyskiego, kanclerza i hetmana wielkiego koronnego, t. 1, wyd. W. Sobieski, Warszawa 1904, s. 389-391, 395-397, 401, 403, 469 n., 501, przyp. 3; por. Joannis Sarii Zamosci De senatu Romano libri duo [...], Argentorati 1608; S. Starowolski, Elogium funebre magni olim Senatoris Thomae Zamoscii Sarii Supremi regni Poloniae Cancellarii etc., Zamoscii 1638, cyt. za: F. Bentkowski, Historya literatury polskiey wystawiona w spisie dziet drukiem ogłoszonych, t. 1, Warszawa-Wilno 1814, s. 9; S. Okolski, Orbis Polonus, t. 1, Cracoviae 1641, s. 335-337.

${ }^{6}$ Zob. Geoportal krajowy, <https://mapy.geoportal.gov.pl/imap/Imgp_2.html?gpmap=gp0\&> [dostęp: 24.01.2020]; BCzart., rkps 1099, Rejestr podatku pogłównego prowincji małopolskiej w 1676 r., s. 737; por. J. Maroszek, Dolina Nereśli w przeszlości, „Białostocczyzna”, 1997, nr 2, s. 7; A. Laszuk, Zaścianki i królewszczyzny. Struktura własności ziemskiej w województwie podlaskim w drugiej połowie XVII wieku, Warszawa 1998, s. 28 , przyp. 13. 7 Zob. np. Нацыянальны гістарычны архіў Беларусі, f. 1708, op. 1, nr 202, k. 307v; Akta albo sprawy sądów miasta knyszyńskiego 1553-1580, oprac. J. Maroszek, Białystok 1999, s. 196.

${ }^{8}$ Acta expeditionum bellicalium palatinatus Calissiensis et Posnaniensis in Valachos et in Turcas a. 1497-1498 in Archivo regio Posnaniensi asservata, t. 1, wyd. M. Bobrzyński, Cracoviae 1882, s. 57 n., 118, 140 n.; MRPS, t. 4, cz. 1, wyd. T. Wierzbowski, Varsoviae 1910, s. 58, nr 978; s. 85, nr 1426; BKórn., Teki Dworzaczka, s.v. Stoliski, Stholiski, Stoliska, etc., <http://teki.bkpan.poznan.pl/index_regesty.html>; Korona w II połowie XVI wieku, $<$ http://hgisb.kul.lublin.pl/azm/pmapper-4.2.0/map_default.phtml> [dostęp: 25.01.2020]. 
w służbie Jeremiego Mohyły ${ }^{9}$ Podana nieco dalej odnośnie do Grajewskich (s. 57, przyp. 113) informacja, że „w jednym dokumencie zamiast Hieronima został wymieniony Jarosz" zdaje się sugerować, jakoby miały to być dwie różne osoby. Tymczasem Jarosz to spolszczona forma imienia Hieronim. Jeszcze dalej (s. 88, przyp. 180) forma przymiotnikowa „niedziedzka włóka" utworzona od nazwy osobowej Niedźwiedź, poprawnie zresztą skojarzonej przez Wydawcę, została przezeń błędnie wzięta za nazwisko Niedźwiedzki.

Także w kwestii nazewnictwa opisywanych miejscowości Edytor osiągnął dobre rezultaty. Tutaj szczególnie przydała się lustracja z 1664 r. Dzięki skorzystaniu z niej udało się poprawnie odczytać nazwy miejscowości nawet w tak trudnych i mylących przypadkach, jak Rybołowy (obecnie Kaniuki, s. 83) i Ryboły (dawniej Antonowice, s. 81) czy Podrzecze (obecnie Pilipki, s. 88) i Podrzeczany (dawniej Łoknica, s. 91). Tylko w jednej sytuacji, jak się zdaje, doszło do drobnej pomyłki - mianowicie względem Kalinówki, a raczej dwóch Kalinówek: Wydawca zarówno oderwaną od starostwa knyszyńskiego posiadłość Kurzenieckich (s. 37, przyp. 71), jak i tę pozostającą w granicach goniądzkiego (s. 50, przyp. 102) przyporządkował obecnej Kalinówce Królewskiej. Jest to poprawne tylko w odniesieniu do tej drugiej, która zresztą właśnie nieprzerwanej przynależności do królewszczyzny zawdzięcza drugi człon swej nazwy. Pierwsza z nich zaś to położona tuż obok dzisiejsza Kalinówka Kościelna, którą Autor edycji słusznie skojarzył z Wójtowcami (s. 32, przyp. 77). Pewną niekonsekwencją jest nierozwiązanie w przypisie rzeczowym dawnych nazw niektórych folwarków (s. 31, 48, 52, 67, 73), podczas gdy inne rozwiązano (s. 6, 15, 42, 59, 83). Trzeba jednak nadmienić, że w przypadku Dobrzyniewa, Szpakowa oraz wspomnianej już problematycznej nazwy miejscowej Potyczina przypis pojawił się nieco dalej, przy siołach tej nazwy (s. 33, 49 i 54). W przypadku wsi Saczielij/ Szaciły (s. 45, przyp. 94) Wydawca błędnie sugeruje pomyłkę pisarza, gdyż zanotowana tu forma graficzno-językowa, którą można czytać „Sacieły”, nie odbiega wszak od tej z 1616 r. - Saciły.

W edycji można znaleźć liczne przypisy rzeczowe odnoszące się do archaicznych słów, sformułowań i terminów, ułatwiające lekturę osobom bez biegłej znajomości staropolszczyzny. Jednakże wyznaczenie granicy między tym, co tłumaczyć, a czego nie, stanowi zadanie niełatwe, przez co można uzyskać wrażenie niekonsekwencji. Oto bowiem objaśnione zostały m.in. rzeczownik kownata (s. 3, przyp. 5) i przymiotnik tuteczny (s. 6, przyp. 11), nie doczekały się go zaś takie sformułowania jak solanka (s. 28), dwornica (s. 43), łopatki (w znaczeniu ,daniny/opłaty” - s. 5, 40), włóki pociągłe i czynszowe (s. 9, 15), czynsz goły i osadny (s. 11, 13), czarna i biała izba (s. 17, 23), wypust (s. 19), młyn na wymiarze (s. 85). Mimo że nie jest wymogiem instrukcji wydawniczej tłumaczenie zwrotów łacińskich, to jednak powtarzający się zapis decima detracta (np. s. 22) i pojedynczy sartatecta (s. 56) aż się prosiły o rozwiązanie w przypisie. Można też pokusić się o drobne uzupełnienie. Występujące w tekście „zapustowe”, oznaczone w edycji jako „nieznana bliżej opłata” (zob. s. 41, przyp. 87), uiszczano prawdopodobnie od korzystania z drewna z zapustu, czyli samosiewnego lasku ${ }^{10}$.

Nie ustrzegło się omawiane wydawnictwo od działalności „chochlika drukarskiego”, lecz tzw. literówki pojawiają się bardzo rzadko, co świadczy o dużej staranności Wydawcy i sprawności korekty. Najbardziej rzucają się w oczy w nazwach własnych: Doslistwo zamiast Dolistowo (s. 110) i Prochalska zamiast Prochaska (s. 67, przyp. 140).

Najpoważniejszym minusem edycji jest brak załączonej mapy. Wydawca uznał wprawdzie tę przygotowaną na potrzeby lustracji podlaskich wydanych w 1959 r. za „w zupełności wystarczającą” (s. XXIV, przyp. 59), lecz swego czasu została ona oceniona nisko ${ }^{11}$. Jakkolwiek decyzja jest o tyle zrozumiała, że wykonanie spełniającej kryteria mapy pochłonęłoby sporo pracy, czasu i kosztów, stając się może obciążeniem dla edycji, ta jednak z pewnością w ostatecznym rozrachunku zyskałaby na tym. Pewnego rodzaju ekwiwalentem, który może po części zrekompensować nam ów niedosyt, jest piękna okładka, przedstawiająca okolice Knyszyna i Goniądza. Niestety, w żadnym miejscu książki nie podano źródła tej ilustracji, można jednakowoż wydedukować, że mamy do czynienia ze znaną XVI-wieczną mapą z zasobu Biblioteki Uniwersytetu Wileńskiego ${ }^{12}$.

Lustracja województwa podlaskiego 1602 roku wydana przez M. Sierbę to praca potrzebna, wykonana profesjonalnie i umiejętnie. Dostrzeżone z recenzenckiego obowiązku nieliczne drobne niedociągnięcia w żadnym razie nie umniejszają jej wartości. Najprostszym środkiem do ich zminimalizowania w przyszłości byłoby może utworzenie zespołu chociażby dwuosobowego i dokładne skolacjonowanie tekstu. Cieszy fakt, że Autor omawianej edycji planuje dalsze prace edytorskie nad lustracjami podlaskimi, można się bowiem spodziewać wysokiej jakości efektu końcowego.

Emil Kalinowski

Biblioteka Narodowa $w$ Warszawie

\footnotetext{
${ }^{9}$ Nowiny o porazeniu Heremiego Mohily Hospodara Woloskiego od Mihala Siedmigrodzkiego i Multanskiego Voievody, w: I. Corfus, Mihai Viteazul şi Polonii: cu documente inedite în anexe, Bucureşti 1937, s. 286 (1600 r.); Kościoły i klasztory rzymskokatolickie dawnego województwa ruskiego, t. 14, oprac. A. Betlej i in., Kraków 2006, s. 321 (1610 r.); W. Kaczorowski, Małopolanie wśród elektorów Władysława IV, St. Hist., 27, 1984, nr 4, s. 588, nr 189-190 (1632 r.).

${ }^{10}$ Zob. Encyklopedia PWN, s.v. zapust, <https://encyklopedia.pwn.pl/szukaj/zapust.html> [dostęp: 24.01.2020]; S.B. Linde, Stownik języka polskiego, t. 6, Lwów 1860, s. 867, s.v. zapust; L. Finkel, Miasto Tarnopol w roku 1672, Tarnopol 1892, s. 15, 31.

11 W. Ochmański, rec.: Lustracje, s. 343.

12 Vilniaus Universiteto Biblioteka, f. 23, nr 135, cyt. za: J. Maroszek, Pogranicze Litwy i Korony w planach króla Zygmunta Augusta. Z historii dziejów realizacji myśli monarszej między Niemnem a Narwią, Białystok 2000, s. 23. Więcej o mapie zob. S. Alexandrowicz, Mapy majątkowe pótnocnego Podlasia z XVI wieku, Kwart. HKM, 14, 1966, nr 2, s. 296-300.
} 


\section{Magdalena Piskała, Polski świat znaków. Studia o herbarzu Szymona Okolskiego, Studia Staropolskie. Series Nova, t. 47 (103), Instytut Badań Literackich Pol- skiej Akademii Nauk, Warszawa 2017, ss. 333}

W ostatnim czasie można zaobserwować wyraźną zmianę w podejściu badaczy do staropolskich herbarzy. Przez długi czas te heraldyczno-genealogiczne dzieła stanowiły swoistą „ziemię niczyją”, nie budząc zainteresowania ani literaturoznawców, ani historyków. Dla tych pierwszych herbarze sprowadzały się do pozbawionych większych walorów literackich prac prezentujących herby i ich użytkowników, dla tych drugich - do utworów panegirycznych, niemal bezwartościowych z punktów widzenia historyczno-genealogicznego. Herbarzem, pod którego adresem tego typu zarzuty padały najczęściej i najmocniej, był trzytomowy Orbis Polonus autorstwa dominikanina Szymona Okolskiego, wydany w Krakowie w latach 1641-1645. Fakt, że właśnie ten herbarz stał się ostatnio przedmiotem żywego zainteresowania ze strony literaturoznawców i historyków ${ }^{1}$, najlepiej pokazuje, jak zmienił się stosunek polskiej nauki do tych wyjątkowych zabytków staropolskiego piśmiennictwa.

Recenzowana książka stanowi pierwszą w polskiej literaturze próbę monograficznego opracowania monumentalnego i wielowymiarowego dzieła, za jaki należy uznać Orbis Polonus. Autorka jest znawczynią literatury barokowej, specjalizuje się w twórczości nowołacińskiej z obszaru Rzeczypospolitej. Publikacja stanowi rezultat jej wieloletnich badań nad dziełem Okolskiego, sięgających przynajmniej 2009 r. Opublikowała na ten temat kilka artykułów.

Stosownie do perspektywy swojej dyscypliny, Magdalena Piskała zawęziła zakres pracy. Jak napisała we wstępie: „Książka niniejsza lukę tę [brak monografii herbarza - J.R.] pragnie wypełnić, ale też jedynie częściowo. [...] Jej tematem nie jest bowiem heraldyka" (s. 8). Wskazuje natomiast cztery pola badawcze, które dla niej jako literaturoznawcy mają największe znaczenie. Po pierwsze, pragnie spojrzeć na herbarz jak na „szczególną antologię tekstów”, po drugie - przyjrzeć się „erudycji literackiej” Okolskiego, po trzecie - zastanowić się nad stylem dzieła, tj. nad zakresem i charakterem przytaczanej w nim antycznej i nowożytnej literatury, wreszcie po czwarte - przyjrzeć się „użyteczności” herbarza, czyli jego oddziaływaniu na czytelników i twórców (s. 16-18). Prezentację założeń książki kończy słowami: „Tym właśnie zagadnieniom jest poświęcona niniejsza książka [...]. Interesujące jest właściwie wszystko to, co historycy postrzegają deprecjonująco jako chaos, w nim bowiem kryje się właściwa treść dzieła" (s. 18).

Biorąc pod uwagę obszerność i wielowątkowość herbarza Okolskiego, nie może dziwić, że Autorka ograniczyła zakres swoich badań. Niemniej rozgraniczenie, jakie próbuje przy tym postawić pomiędzy materiałem badawczym historyka a literaturoznawcy, wydaje się sztuczne i nie do końca potrzebne. Po pierwsze, zajmując się nawet wybranymi aspektami dzieła Okolskiego, nie sposób uciec od problematyki heraldycznej i historycznej - i rzeczywiście M. Piskała, nieco wbrew własnym zapowiedziom, wielokrotnie wkracza na ten obszar, czyniąc to z pewnym znawstwem. Z drugiej zaś strony historiografia już od dość długiego czasu nie traktuje staropolskich herbarzy wyłącznie jako „bałamutnych” źródeł do heraldyki i genealogii, ale dostrzega w nich wyjątkowy potencjał badawczy, pozwalający lepiej zrozumieć kulturę szlachecką, i to zarówno w jej wymiarze duchowym (kultura historyczna, świadomość genealogiczna, tożsamość narodowa, stanowa i rodowa), jak i materialnym (środki identyfikacji stanowej i rodowej, znaki władzy, fundacje). Problemy, na których koncentruje się w książce M. Piskała - podstawa źródłowa pracy, warsztat autora, funkcje dzieła czy też jego odbiór, w zupełności mieszczą się w obrębie zainteresowań społeczno-kulturowych badaczy elit dawnej Polski. Na herbarz Okolskiego składają się trzy wzajemnie dopełniające się komponenty: genealogiczno-historyczny, heraldyczno-ikonograficzny i historyczno-filologiczny. Próba wydzielenia tego ostatniego jako „właściwej treści dzieła” i umniejszenie znaczenia dwóch pozostałych nie wydaje się dobrym punktem wyjścia studiów nad dziełem, które mimo szczególnej formy stanowi wciąż pracę heraldyczno-genealogiczną.

Recenzowana książka dzieli się na dwie zasadnicze części: Znaki erudycji oraz Znaki szlachectwa. We wstępie Autorka nie wyjaśnia, co dokładnie rozumie pod tymi efektownie brzmiącymi tytułami, dopiero lektura wchodzących w ich skład rozdziałów rozjaśnia strukturę pracy. I tak Znaki erudycji okazują się zabytkami piśmiennictwa, na których opierał się Okolski, opracowując dzieło - część ta stanowi więc analizę podstawy źródłowej herbarza. Znaki szlachectwa z kolei należy rozumieć jako herby opisane i zinterpretowane przez dominikanina - Autorka nie analizuje tu jednak zespołu heraldycznego obecnego na kartach Orbis Polonus, ale w kilku odrębnych studiach omawia problemy związane z zawartością i funkcjonowaniem herbarza (w tym budowę haseł herbowych i wkład dzieła do heraldyki - a więc mimo wszystko jest to praca o heraldyce). Książka zawiera ponadto zakończenie zatytułowane „Orbis Polonus” wobec staropolskiego piśmiennictwa heraldycznego². Autorka omawia tutaj specyfikę gatunkową staropolskich herbarzy, w tym kontekst armoriałów zachodnioeuropejskich, dlatego też wydaje się, że fragment ten powinien znajdować się na samym początku książki, gdyż dla mniej zorientowanego czytelnika stanowiłby znakomite wprowadzenie do złożonej problematyki badanego dzieła.

\footnotetext{
${ }^{1}$ Ożywienie badań nad herbarzem Okolskiego jest związane z projektem badawczym „Polskojęzyczna edycja »Orbis Polonus« Szymona Okolskiego - źródło do badań nad kulturą i świadomością społeczeństwa polskiego”, który od 2009 r. był realizowany w Ośrodku Badań nad Tradycją Antyczną w Polsce i Europie Środkowowschodniej Uniwersytetu Warszawskiego pod kierunkiem B. Milewskiej-Waźbińskiej. W związku z tym projektem 12-13 IV 2013 w Warszawie odbyła się konferencja „Herb i heraldyka w kulturze staropolskiej”, z której materiały zostały opublikowane w Rocz. Herald., nowa seria, 13 (24), 2014. Powstanie recenzowanej pracy również pozostaje w związku z tym projektem, jako że Autorka należała do grona jego wykonawców. W książce jednak nie odnajdujemy wzmianki o tym ważnym grancie.

2 Zakończenie niemal w pełni pokrywa się z treścią wcześniejszego artykułu Autorki: M. Piskała, Herbarz (staropolski) jako gatunek literacki, „Teksty Drugie", 2015, z. 1, 337-257, co jednak nie zostało odnotowane we właściwy sposób - Autorka jedynie na początku (s. 8, przyp. 8) wspomniała ogólnikowo, że artykuł został wykorzystany w książce, nigdzie jednak nie uściślając, że został on zacytowany w zakończeniu in extenso.
} 
Pierwsza część recenzowanej książki wzbudza podziw ogromem i różnorodnością prac, które M. Piskała ustaliła jako źródła odwołań obecnych na kartach badanej pracy. Autorka odtwarza tutaj „listę lektur” Okolskiego, która obejmowała całą gamę najróżniejszych zabytków, pism i utworów, począwszy od źródeł o charakterze historiograficznym, normatywnym i okolicznościowym, poprzez kompendia i słowniki z zakresu szeroko rozumianej symbolografii, przyrodoznawstwa i astrologii, a skończywszy na zabytkach piśmiennictwa filozoficznego, etycznego i teologicznego. W materiale tym odnajdujemy zabytki o proweniencji polskiej i europejskiej, powstałe tak w czasach współczesnych autorowi, jak i w epokach wcześniejszych (szczególnie literatura antyczna). Wydaje się, że Autorka nie pominęła żadnego utworu, który Okolski wskazał jako źródło podawanych informacji, sentencji czy cytatów. Jej pieczołowitość w śledzeniu i identyfikacji często bardzo niejasnych odwołań stanowi o szczególnej wartości recenzowanej książki. Ukazuje rozległość horyzontów Szymona Okolskiego, którego można określić nie tylko mianem heraldyka i genealoga, ale także barokowego antykwarysty, polihistora i encyklopedysty.

M. Piskała odtworzyła „listę lektur” dominikanina ze wzorcową akrybią. Dlatego też tym większy zawód sprawia nieco chaotyczny sposób, w jaki zaprezentowała wyniki swoich żmudnych ustaleń. Podstawę herbarza pogrupowała bowiem nie według rodzajów lub gatunków źródeł, ale według funkcji i celu, dla których zostały one w dziele przytoczone. I tak omawia osobno: źródła do heraldyki i genealogii, źródła do antykizowania herbów i kompendia wiedzy o antyku, źródła do analizy semiotycznej, źródła panegiryczne (stemmaty), źródła wykładu etycznego oraz źródła będące dorobkiem literackim rodzin szlacheckich (jak więc widzimy, nie jest to podział w pełni konsekwentny). Taki układ treści został zapewne podyktowany koniecznością uporządkowania wyjątkowo różnorodnej materii. Sprawia on niewątpliwie erudycyjne wrażenie, ale w praktyce okazuje się dla czytelnika niewygodny, niektóre kategorie źródeł - szczególnie te, które Okolski wykorzystywał dla różnych celów - są bowiem omawiane w wielu miejscach. Dotyczy to zwłaszcza kluczowych dla warsztatu dominikanina licznych utworów historiograficznych i okolicznościowych - w książce nie odnajdziemy wykazu tych źródeł w jednym miejscu, ale trzeba $\mathrm{w}$ tym celu przewertować aż trzy różne rozdziały.

Na tym nie kończą się problemy z kompozycją Znaków erudycji. Rozdziały poświęcone wskazanym przez Autorkę grupom źródeł dzielą się z kolei na podrozdziały poświęcone konkretnym rodzajom zabytków i utworów (wyodrębnianych znów nie do końca konsekwentnie). Treść niemal wszystkich tych podrozdziałów wypełniona jest dociekaniem, czy z danych źródeł mógł Okolski korzystać bezpośrednio, czy też zapożyczył je w formie odwołań lub cytatów z innych dzieł. Jest to oczywiście analiza o fundamentalnym znaczeniu dla poznania warsztatu twórcy herbarza, pozwala ustalić jego „rzeczywistą listę lektur”. Badaczka wywiązuje się z tego zadania znakomicie. Kłopot polega jednak na tym, że wyniki tych ustaleń zostały ponownie przedstawione w sposób nieprzejrzysty. W wielu podrozdziałach okazuje się bowiem, że analizowana grupa źródeł znalazła się na kartach herbarza niemal wyłącznie za pośrednictwem innych dzieł, z których Okolski korzystał w największym stopniu. Pojawia się więc pytanie, czy zasadne było poświęcać im osobną uwagę, skoro źródeł tych twórca herbarza nigdy w ręku nie miał? Trudno nie odnieść wrażenia, że lepszym rozwiązaniem byłoby oprzeć konstrukcję pracy na tych źródłach, które udało się ustalić jako bezpośrednio spożytkowane przez dominikanina.

Zasadniczym problemem, jaki wynika z takiego układu pracy, jest jednak rozmycie informacji o tych herbarzach, kronikach i kompendiach, na podstawie których Okolski w największym stopniu skomponował herbarz, czerpiąc z nich najwięcej wzmianek i cytatów. Informacje o tych dziełach są rozsiane w niemal całej obszernej części. Najlepiej obrazuje to przykład herbarzy Bartosza Paprockiego. W podrozdziale poświęconym polskim herbarzom Autorka kwestię korzystania Okolskiego z tych dzieł zamyka ogólnikowym stwierdzeniem: „Fundamentalne znaczenie dla jego [tj. Okolskiego - J.R.] pracy miały natomiast Paprockiego Gniazdo cnoty (Kraków 1578) oraz Herby rycerstwa polskiego (Kraków 1584)" (s. 24). Stwierdzenia tego nie popiera w tym miejscu żadnymi szczegółowymi danymi. W rezultacie czytelnik, chcąc dokładnie dowiedzieć się, jakiego rodzaju i jak liczne są treści zaczerpnięte z dzieł Paprockiego, zmuszony jest przeczytać Znaki erudycji w całości, wyłuskując z tej części bardzo liczne wzmianki o cytatach i odwołaniach, które Autorka ustaliła jako zapożyczone z Gniazda cnoty lub Herbów rycerstwa polskiego.

Wspomniany wyżej brak szczegółowych danych stanowi kolejny istotny mankament omawianej części. Z niewiadomych powodów M. Piskała nie podaje nawet orientacyjnych obliczeń obrazujących, jak wiele źródeł danego rodzaju bądź też odnośników do poszczególnych dzieł znalazło się na kartach herbarza. Takie dane odnajdujemy tylko w jednym przypadku: Biblii - Autorka podaje precyzyjną liczbę odwołań do Pisma Świętego: 275 (s. 130). Przypadek ten pokazuje, że M. Piskała sporządzała takie obliczenia, dlatego też tym większa szkoda, że nie zdecydowała się nimi podzielićs. W rezultacie czytelnik jest pozbawiony możliwości weryfikacji często dość ogólnikowych stwierdzeń Autorki dotyczących zakresu, w jakim Okolski przytaczał niektóre rodzaje źródeł i w jakim korzystał z tak podstawowych dzieł jak herbarze, kroniki i kompendia.

Jak już wspomniano, druga część książki - Znaki szlachectwa - stanowi zbiór studiów, w których M. Piskała analizuje dzieło Okolskiego pod kątem różnych funkcji, jakie miało ono pełnić. Omawia Orbis Polonus jako herbarz, jako tekst o znakach i ich znaczeniu, jako utwór o charakterze parenetycznym, jako prognostyk i wreszcie jako zbiór kazań okolicznościowych. Część ta zawiera także podsumowanie, które jednak nie syntetyzuje wcześniejszych studiów, ale stanowi omówienie kolejnych nie mniej ważnych problemów, takich jak reakcje czytelników i recepcja dzieła. Trudno więc nie odnieść wrażenia, że te fragmenty znalazły się w niniejszej części nieco przypadkowo, gdyż znacznie lepiej pasowałyby do wstępu lub zakończenia.

\footnotetext{
3 Jest to tym bardziej zastanawiające, że Autorka uznała za wzorcową (s. 15) monografię Iwony Dackiej poświęconą herbarzowi Korona Polska Kaspra Niesieckiego, w której to książce odnajdujemy przecież skrupulatne wyliczenia dotyczące liczby cytowań poszczególnych dzieł czy źródeł; I.M. Dacka, „Korona Polska” Kaspra Niesieckiego. Pomnik staropolskiego piśmiennictwa heraldycznego, Warszawa 2004, passim.
} 
Znaki szlachectwa stanowią bardzo interesującą lekturę, a to ze względu na wszechstronne spojrzenie na treść, formę i funkcje herbarza Okolskiego. M. Piskała, opierając się na wnikliwej rekonstrukcji podstawy źródłowej, a także korzystając z dotąd opublikowanej literatury poświęconej herbarzowi, rzuca światło na szereg podstawowych kwestii związanych z założeniami, stylem i przeznaczeniem Orbis Polonus. Rekonstruuje proces powstawania dzieła, ustala strukturę haseł herbowych, thumaczy obecność na jego kartach sentencji i cytatów z literatury antycznej oraz nowożytnej, odczytuje propagowany tą drogą wizerunek cnotliwego szlachcica. Zwraca uwagę na nowoczesność i uniwersalność herbarza, który pod względem języka (łacina), lipsjańskiej formy i erudycyjnej maniery sytuował się w „centrum obowiązujących trendów europejskiego pisarstwa nowołacińskiego tego okresu" (s. 228). Lektura tej części pracy sprawia, że Orbis Polonus staje się dziełem znacznie bardziej zrozumiałym i przystępnym. Można więc powiedzieć, że omawiana część stanowi swego rodzaju „instrukcję obsługi” tego wyjątkowego herbarza.

M. Piskała wyczerpująco omawia wspomniane wyżej zagadnienia, jakkolwiek w niektórych miejscach odnosi się wrażenie, że pewne szczególnie ważne ustalenia warto byłoby podeprzeć analizą większej liczby przykładów zaczerpniętych z treści dzieła. Nieco dyskusyjne wydają się także spostrzeżenia Autorki podsumowujące warsztat i erudycję Okolskiego. Lekturze niemal całej książki towarzyszy bowiem wrażenie, że M. Piskała stara się wytłumaczyć dominikanina z „powierzchownej uczoności”, wynikającej stąd, że rzeczywista lista wykorzystywanych przez niego dzieł była znacznie węższa niż ta zestawiona na podstawie wszystkich odniesień obecnych na kartach dzieła. W niektórych miejscach Autorka wręcz posądza Okolskiego o celowe manipulowanie czytelnikiem. Wydaje się jednak, że takie spojrzenie na warsztat barokowego naukowca jest nieco anachroniczne. Za kluczowy należy uznać inny zaobserwowany przez Autorkę fakt: „mimo ograniczonej w gruncie rzeczy tematyki podejmowanej w herbarzu, nie ma dwóch takich samych haseł [dowodzących szlachectwa rodzin - J.R.]. Powtórzenia argumentów, choć się zdarzają, również należą do rzadkości” (s. 177). Szkoda, że Autorka nie poświęciła tej kwestii więcej uwagi, gdyż wydaje się, że nie tyle na liczbie przytaczanych źródeł i prac, ile na niezwykłym urozmaiceniu treści, na przytaczaniu coraz to nowych dowodów i ciągłym zaskakiwaniu czytelnika polegały uczoność i kunszt barokowego uczonego, jakim bez wątpienia był Szymon Okolski.

Należy podkreślić, że na gruncie badań nad herbarzem Okolskiego książka M. Piskały ma charakter pionierski. Biorąc przy tym pod uwagę specyfikę tego dzieła - wyjątkową nawet na tle pozostałych dzieł heraldyczno-genealogicznych epoki - nie mogą dziwić pewne braki oraz nie do końca trafne rozwiązania przyjęte w kompozycji książki. Mankamenty te nie umniejszają jednak znaczenia skrupulatnych i wyczerpujących studiów, które M. Piskała przeprowadziła nad tak skomplikowaną i różnorodną materią. Jej badania oczywiście nie wyczerpują całości problematyki tego obszernego herbarza. Wciąż pozostaje tutaj wiele do zrobienia, szczególnie w zakresie znaczenia Okolskiego dla staropolskiej genealogii. Recenzowana książka stanowi jednak milowy krok w kierunku pełnego rozpoznania i zrozumienia jego Orbis Polonus.

Jakub Rogulski Instytut Historii

Uniwersytet Jagielloński

\section{Agnieszka Pawłowska, Ikonografia godel cechowych na Pomorzu brandenbur- sko-pruskim, Wydawnictwo Naukowe Uniwersytetu Szczecińskiego, Szczecin 2019, ss. 383, il.}

Recenzowana praca została poświęcona analizie ikonograficznej godeł cechów na Pomorzu brandenbursko-pruskim od połowy XVII do początku XIX w. Autorka scharakteryzowała organizacje cechowe w określonym kontekście dziejowym, a następnie podjęła się zbadania genezy godeł, dalej przedstawiła ich opis według specjalizacji poszczególnych organizacji cechowych, omówiła ikonografię godeł i ich symbolikę, a także zbadała kwestie dotyczące ich heraldyzacji. Badaczka postanowiła przedstawić powyższą problematykę na tle porównawczym. Praca składa się ze wstępu (s. 7-19), trzech rozdziałów (s. 21-159), zakończenia (s. 161-164), wykazu archiwaliów i opracowań (s. 165-176) oraz katalogu zawierającego liczne barwne zdjęcia (s. 177-380). Na końcu umieszczono streszczenie pracy w języku niemieckim (s. 381 n.) oraz wykaz autorów zdjęć (s. 383).

Na wstępie uporządkowania wymaga definicja godła cechowego użyta przez Autorkę. Zastrzegła ona, że rozumie je jako znak o zawężonym znaczeniu. Można oczekiwać zatem, że praca dotyczy godeł herbowych. W praktyce termin ten jest jednak stosowany przez Autorkę możliwie szeroko i odnosi się do różnych znaków ${ }^{1}$. W konsekwencji umyka funkcjonowanie herbów w cechach. Tworzenie godeł należy ściśle związać z zaistniałym w części organizacji cechowych procesem heraldyzacji. Wystarczające jest zatem posłużenie się w wielu przypadkach pojęciem „,znak”, unikając nadużywania terminu „godło”. Autorka w dalszej części wstępu stwierdza, że ,godła cechów jako znaki o funkcjach i charakterze heraldycznym należą do obszaru szeroko rozumianej heraldyki miejskiej” (s. 8). Takie sformułowanie jest wszakże niezbyt zręczne, gdyż przyrównuje znaczną część znaków cechowych do herbów. Zdaniem Autorki: „stanowiło ono [tj. godło - T.K.] w zasadzie odpowiednik herbu" (s. 10). Nie zawsze Badaczka jest precyzyjna. W innym miejscu pracy (s. 14) wskazała bowiem odmienne rozumienie godła, które wyróżniła w ramach znaków. Definiując godła jako znaki, wkroczyła na grunt semiotyki. Przytaczając definicję Jerzego Pelca, zwróciła uwagę na stronę funkcjonalną znaku. Nie poświęciła jednak więcej miejsca omówieniu nośników znaków. Nie dowiadujemy się również, ile zabytków cechowych z badanego terenu miało inne wyobrażenia lub inskrypcje.

${ }^{1}$ W niniejszym tekście, o ile nie wskazuję inaczej, posługuję się terminem „godło” w rozumieniu Autorki. 
Zakres terytorialny pracy objął 48 miast z terenu Pomorza władanego przez Brandenburgię-Prusy od połowy XVII w., a także ziemie uzyskane w 1679 r., powiększone następnie w 1721 r. o obszar między Odrą a Pianą. Ramy chronologiczne wskazane przez Autorkę to lata 1653-1805. Głównym determinantem były zatem zmiany polityczne na obszarze ziem dawnego księstwa pomorskiego. Cezurę dolną wyznaczyło ustalenie granicy w $1653 \mathrm{r}$. w wyniku podpisania pokoju westfalskiego (1648), a górną - zmiany zapoczątkowane wkroczeniem armii Napoleona na tereny Rzeszy Niemieckiej. W tym czasie następowały, co słusznie zauważyła Autorka, przeobrażenia gospodarcze, które rzutowały także na funkcjonowanie organizacji cechowych. Przyjęte daty wymagają krótkiego komentarza. Zwyczajowo granicę dolną wyznaczają najstarsze znane źródła. Uważam, że jest to najlepsze uzasadnienie do określenia cezury początkowej. Badaczka zaznaczyła, że średniowiecze oraz okres nowożytny do połowy XVII w. zasługuje również na zbadanie, jednak nie wytłumaczyła, dlaczego nie udało się tego wykonać w niniejszej pracy. Nie pozwala to na prześledzenie pełnego rozwoju znaków cechowych na Pomorzu i stanowiło dodatkową trudność w doborze źródeł z wyznaczonego przez Autorkę okresu. Granica górna recenzowanej książki jest trudniejsza do wyznaczenia. We własnej pracy, zbliżonej tematycznie do recenzowanej, wskazałem na zmiany, które zasadniczo dotknęły cechy w pierwszej połowie XIX w. Kluczowe było wprowadzenie wolności przemysłowej ustawami w 1810 i 1811 r., a także wydanie ustaw o rzemiośle w 1845 i 1849 r., obejmujących zasięgiem całą monarchię pruską. Wpłynęło to na reorganizację prawną cechów, m.in. zarządzono rewizję dotychczas obowiązujących statutów i nakazano wprowadzenie nowych rozporządzeń. W konsekwencji, jak zaobserwowałem, cechy stopniowo wycofywały z użycia dawne pieczęcie². Granica końcowa pozostaje jednak płynna, gdyż część zabytków pozostawała w użyciu również w drugiej połowie XIX w. Przyjęcie w recenzowanej książce cezury bliższej przynajmniej połowie tego stulecia wydaje się bardziej uzasadnione.

Agnieszka Pawłowska wyszczególniła również źródła, które wykorzystała w pracy. Uwzględniła zabytki cechowe znajdujące się w Muzeum Narodowym w Szczecinie oraz źródła przechowywane w Archiwum Państwowym w Szczecinie, w Koszalinie i jego oddziale w Słupsku. Na pochwałę zasługuje sięgnięcie do zbiorów zagranicznych. Wykorzystano bowiem materiały znajdujące się w Landesarchiv w Greifswaldzie. Szkoda, że nie podjęto próby przeprowadzenia kwerendy w Geheimes Staatsarchiv Preußischer Kulturbesitz w Berlinie. Przykładowo w tamtejszych kolekcjach pieczęci, według mojego rozeznania, znajdują się pieczęcie miejskie Szczecina. Warto w przyszłości zbadać ten zasób pod kątem pieczęci cechowych. W zebranym przez A. Pawłowską materiale źródłowym przeważają pieczęcie. Według katalogu zamieszczonego w drugiej części pracy na 412 obiektów tylko ok. 50 to zabytki cechowe (m.in. kubki, kufle, skrzynki, wilkomy, wywieszki), a pozostałe to właśnie pieczęcie. Przewaga zgromadzonych źródeł na rzecz sfragistyki jest zauważalna w części analitycznej oraz w katalogu. Z tych względów warto było recenzowaną pracę poświęcić przede wszystkim pieczęciom, a pozostałe znaki potraktować jako dopełnienie narracji.

We wstępie A. Pawłowska dokonała również przeglądu literatury. Zestawienie nie odnotowuje jednak ważnych prac dotyczących pieczęci cechowych wydanych po 2010 r. Wymienić należy przede wszystkim obszerny katalog zawierający kilkadziesiąt tłoków cechowych z Wielkopolski ${ }^{3}$. Z prac obcojęzycznych zwraca uwagę dwutomowa publikacja głównie czeskich pieczęci ${ }^{4}$.

W pierwszym rozdziale ukazano najpierw kontekst, w którym funkcjonowały cechy pomorskie. Autorka przedstawiła m.in. szereg cennych uwag dotyczących regulacji państwowych wobec cechów w XVIII w. Poprawnie omówiła także struktury istniejących cechów. Wyróżniła cechy pojedyncze, złożone (połączone), rozproszone i działających wolnych mistrzów. W zestawieniu rodzajów organizacji cechowej zbędne jest wyróżnianie cechów rozproszonych (s. 36). Były to zapewne cechy naczelne, sądząc z przytoczonego przykładu kotlarzy pomorskich, którzy założyli cech w 1624 r. Tego typu organizacje zrzeszały przymusowo mistrzów lub cechy z większego obszaru, np. danego księstwa lub ziemi, i posługiwały się własnym statutem ${ }^{5}$. Autorka przedstawiła także zwięźle strukturę wewnętrzną cechu. Interesujące są przykłady regulacji liczby mistrzów, czeladników i uczniów w wybranych cechach pomorskich. Kompetentnie zaprezentowano wszechstronne funkcje cechów dotyczące kształcenia, a także działalności gospodarczej (pozyskiwanie surowca, produkcja, sprzedaż), wojskowej, społecznej, w tym samopomocowej (pomoc chorym i potrzebującym członkom cechu, a także wędrownym czeladnikom) oraz religijnej (udział w uroczystościach kościelnych i pogrzebach członków cechu, utrzymywanie w miejscowych kościołach ołtarzy, tworzenie bractw). Dopełnieniem tych rozważań są ustalenia dotyczące sfery obyczajowej cechów. Zwrócono uwagę na rolę przedmiotów opatrzonych znakami (skrzynki cechowe oraz wilkomy) w czynnościach podejmowanych przez członków cechu (zebrania kwartalne, uczty). Inne obiekty zostały tylko wymienione, jak przykładowo pieczęcie, kubki i chorągwie. Szkoda, że nie omówiono szerzej ich funkcji.

W drugim rozdziale A. Pawłowska podjęła zagadnienie genezy godeł cechowych. W poszukiwaniu źródeł kształtowania się tych znaków sięgnęła do dawnych poglądów, sugerujących wywodzenie się godeł cechowych z chorągwi. Takie spojrzenie jest widoczne w pracach heraldyków niemieckich i czeskich, którzy koncentrowali się jednak na okolicznościach tworzenia herbów cechowych. W nauce polskiej zostało ono przejęte przez część badaczy, którzy stosowali ten termin na różne znaki ${ }^{6}$. A. Pawłowska wskazała również inną drogę uzyskania godeł przez cechy, tj. „decyzję władcy nadającego im godło” (s. 55). Ponownie została zatarta różnica między godłem i herbem. Badaczka ma bowiem na myśli dokumenty herbowe nadawane najczęściej przez cesarza lub króla. Ostatecznie stwierdziła, że cechy przeważnie wzorowały się na godłach cechów już istniejących. Wskazała ponadto, że na początku „były to po prostu jednoczące znaki wspólnotowe, umieszczane przykładowo na

\footnotetext{
2 T. Kałuski, Pieczęcie cechów na ziemiach księstwa głogowskiego do połowy XIX wieku. Geneza i symbolika, Warszawa 2013, s. 12, 24.

${ }^{3}$ Zbiór tłoków i stempli pieczętnych w zasobie Archiwum Państwowego w Poznaniu, red. P. Pokora, współpr. M. Hlebionek, Poznań 2015.

${ }^{4}$ M. Milec, Cechovní pečetě, t. 1-2, Brno 2011-2013.

${ }^{5}$ E. Borkowska-Bagieńska, Cechowe prawo gospodarcze w miastach Wielkopolski w XVII wieku, Poznań 1977, s. 42-45; T. Kałuski, Pieczęcie cechów,

s. 28 (w tej ostatniej pracy zebrana została literatura przedmiotu).

${ }^{6}$ Ostatnio E. Bimler-Mackiewicz, Znaki cechowe i ich funkcje na ziemiach polskich. Studium źródłoznawcze, Warszawa 2004, s. 156 n.
} 
wspomnianych chorągwiach czy pieczęciach” (s. 57). Podała też, że najstarsze znane pieczęcie cechowe z ziem niemieckich pochodzą z XIII w. - niestety nie opatrzyła tego stwierdzenia przypisem. Na podstawie dotychczasowych badań ich pojawienie przyjmuje się jednak dopiero w XIV w. Autorka wskazała natomiast prawidłowo metrykę pieczęci z ziem polskich. Z Pomorza wymieniła najstarsze pieczęcie kowali i szewców szczecińskich z XIV w. W dalszej części stwierdziła, że z upływem czasu „znaki widniejące w polach pieczęci nabrały funkcji godeł herbowych, choć nigdy nie stały się herbami de facto" (s. 58). Powyższe spostrzeżenia nie pozwalają jednak na przejrzyste wyjaśnienie, w jaki sposób tworzono znaki organizacji cechowych w ich początkowym okresie oraz czy cechy faktycznie nie posługiwały się herbami. Na podstawie dotychczasowych badań mogę stwierdzić, że podstawą przy tworzeniu znaków były głównie narzędzia produkcji oraz wyroby, które umieszczano najwcześniej na pieczęciach. Niewykluczone mogło być zaczerpnięcie wyobrażeń z pieczęci innych cechów. Herby przeważnie kształtowały się stopniowo. Przykładowo na Śląsku rozpowszechniły się, podobnie jak herby miejskie, w XVI i XVII w. Najczęściej miały zastosowanie na pieczęciach. Powstawały na drodze heraldyzacji wizerunków napieczętnych lub uzyskania znaku na mocy stosownego dokumentu herbowego ${ }^{7}$.

W dalszej części rozdziału A. Pawłowska postawiła sobie za cel omówienie godeł cechowych według uprawianego rzemiosła (posłużyła się tutaj także współczesnym terminem „branża”). Uczyniła to, zestawiając je z materiałem porównawczym z innych terenów. Był to punkt wyjścia do analizy ikonologicznej, którą postanowiła przedstawić w ostatnim, trzecim rozdziale. W omówieniu wyobrażeń wyszczególniła trafnie takie elementy jak surowce, wyroby, narzędzia oraz świętych (św. Eligiusz w cechu złotników). Wątpliwości budzi podział rzemiosł i zakwalifikowanie do nich części profesji. Cech cieśli został omówiony w rzemiośle drzewnym, mimo że rzemieślnicy z tych organizacji zajmowali się również konstrukcjami budowlanymi. Można było zatem stworzyć grupę rzemiosł drzewno-budowlanych. Należy także poczynić uwagi do grupy rzemiosł różnych. Warto było w odniesieniu do rzemieślników określonych mianem cyrulików, balwierzy, chirurgów i łaziebników - zaliczonych przez Autorkę niezbyt precyzyjnie do branży medyczno-pielęgnacyjnej - dokonać pewnej systematyzacji. Na podstawie źródeł i literatury można wskazać bowiem dwie grupy zawodowe, tj. chirurgów nazywanych często balwierzami oraz łaziebników. $\mathrm{Ci}$ ostatni próbowali z większym lub mniejszym powodzeniem współuczestniczyć w uprawianiu chirurgii ${ }^{8}$. Trudno wyjaśnić rozważania poświęcone ikonografii organizacji kupieckich, ponieważ Autorka w pracy koncentruje się na związkach rzemieślniczych. Kolejny wniosek, który wypływa z drugiego rozdziału, dotyczy doboru źródeł. Są to w większości przypadków pieczęcie cechowe, na co Badaczka zwraca uwagę w podsumowaniu tego rozdziału (s. 118). Analizą objęto zatem wyobrażenia napieczętne oraz herby. Autorka konsekwentnie unika wskazania herbów cechowych na badanej części Pomorza. Zaznacza jednak, że w części organizacji występuje tarcza, która ulega podzieleniu, ponadto wyszczególnia hełm, labry i klejnot (s. 79, 86, 89). A. Pawłowska wymienia również cechy wrocławskie jako przykłady z terenów sąsiednich. Przy opisie pieczęci cechu nożowników wrocławskich poprzestaje na stwierdzeniu, że wyobrażenie występowało „z pełną oprawą heraldyczną” (s. 84). Tymczasem pieczęcie przedstawiają herby w pełnym ujęciu heraldycznym, a ponadto wskazano to w legendzie 9 . Zauważyć należy również, że analiza znaków cechowych zawartych w tym rozdziale obejmuje szerszy okres czasowy, niż zostało to zapowiedziane we wstępie. Autorka przytacza kilka pieczęci z XVI oraz z początku XVII w. (s. 99 n., 109, 113, 118), a zamyka rozważania na drugiej połowie XIX w. (s. 99, 106, 113, 116).

W trzecim rozdziale A. Pawłowska podjęła się analizy godeł cechowych. W tym celu zaproponowała w pierwszym podrozdziale sześć grup, według których omówiła wyobrażenia: ,godła związane z warsztatem pracy, godła związane z gotowym już produktem lub obsługą, godła ze scenami narracyjnymi obrazującymi wykonywanie pracy, godła z motywami religijnymi, godła z elementami herbów miejskich lub państwowych, godła z elementami symbolicznymi” (s. 122). Wymieniona typologia odnosi się do strony ikonograficznej znaków. Niniejsze rozważania powinny zatem znaleźć się w drugim rozdziale jako punkt wyjścia. W ramach poszczególnych grup można było wskazać charakterystyczne motywy, uwzględniając przy tym podział na rzemiosła. Zdarza się, że interpretacja genezy niektórych elementów jest powierzchowna. Przykładowo, rozpowszechnienie wizerunku papugi występującej w cechach łaziebników zawdzięczamy dokumentowi herbowemu Władysława Jagiellończyka z 1509 r., który otrzymali prascy łaziebnicy. Motyw ten następnie pojawił się m.in. w cechach śląskich ${ }^{10}$. A. Pawłowska zastanawia się również nad funkcją dodatkowych elementów, jak gwiazdy czy motywy roślinne. Podstawą rozważań są ponownie pieczęcie (s. 139). Należałoby zatem postawić w tym miejscu pytanie o wpływ warsztatu złotniczego na stylizację pieczęci, w tym na wymienione elementy. Można w ten sposób uniknąć symbolicznego wyjaśniania tego typu motywów (przykładowo pieczęcie rzeźników, s. 142). Prowadzić to może do nadinterpretacji wizerunków napieczętnych.

W kolejnych podrozdziałach Autorka scharakteryzowała znaczenie znaków cechowych oraz kwestie heraldyczne (s. 143-159). Trafnie zauważyła, że najczęściej znaki odnosiły się do aktywności zawodowej rzemieślników (narzędzia i wyroby). Podkreślały przez to najważniejsze zadania, jakie wypełniali w cechach. Badaczka zwróciła przy tym uwagę na realizm wyobrażeń, szczególnie wyrobów. Kolejną cechą znaków była nie tylko ich trwałość, ale i powszechność, niezależnie od regionu. A. Pawłowska dostrzegła, że zbliżone wizerunki pojawiały się w cechach m.in. w drodze recepcji. Obok tego występowały niekiedy

\footnotetext{
7 T. Kałuski, Pieczęcie cechów, s. 62-65.

8 S. Gniatczyńska-Głowacka, Cech cyrulików poznańskich (1517-1780), „Studia i Materiały do Dziejów Wielkopolski i Pomorza”, 5, 1959, nr 1, s. 23; S. Sokół, Historia chirurgii w Polsce, cz. 1: Chirurgia okresu cechowego, Wrocław 1967, s. 8-20; T. Kałuski, Struktur und Berufsaktivität der Chirurgen im Fürstentum Glogau vom 16. bis zum 18. Jahrhundert, „Mitteilungen des Instituts für Österreichische Geschichtsforschung”, 124, 2016, cz. 1, s. 150

9 B. Marcisz, Cechowe pieczęcie i tłoki pieczętne, w: Zabytki cechów śląskich, red. M. Korżel-Kraśna, Wrocław 2002, s. 89 n., nr $231-233$.

10 T. Kałuski, Chirurdzy z księstwa glogowskiego w świetle pieczęci w okresie wczesnonowożytnym, „Сфрагістичний щорічник”, 5, 2015 , s. 396 n.
} 
bardziej zindywidualizowane znaki o charakterze regionalnym. Autorka zwróciła uwagę również na symboliczne znaczenie znaków w życiu jednostki i wspólnoty. Ostatnią kwestią podjętą w rozdziale trzecim była „heraldyzacja godła cechowego" (s. 153). Jednym z najważniejszych elementów w tym procesie była według Badaczki „oprawa herbowa/heraldyczna”. A. Pawłowska zwraca uwagę, że godła otrzymywały oprawę, na którą składała się tarcza, czasem trzymacze i korona, a rzadko hełm z klejnotem i labry. Przedstawiony opis można rozumieć tak, że proces heraldyzacji polegał na wzbogaceniu dodatkowymi elementami ukształtowanych godeł cechowych. Zdaniem Autorki godła nie przekształciły się jednak w herby. Zaciera się przez to moment pojawienia się herbów w organizacjach cechowych i sposoby ich powstawania, o czym pisałem wcześniej. W trzecim rozdziale A. Pawłowska podjęła się przede wszystkim interpretacji ikonologicznej. Należy zatem odnieść się również do zastosowanej metody, o której wypowiedziała się niezwykle oszczędnie. Interpretacja ikonologiczna jest jednym z elementów metody wypracowanej przez Erwina Panofsky’ego, która miała doniosły wpływ na historię sztuki w połowie XX w. Znalazła ona również zastosowanie w badaniach z zakresu nauk pomocniczych historii w Polsce. Autorka ten etap interpretacji rozumie przede wszystkim jako badanie znaczenia symbolicznego znaków cechowych. Jest to jednak nadal analiza ikonograficzna ${ }^{11}$.

Część analityczną pracy zamyka podsumowanie, w którym treściwie zestawiono wnioski dotyczące znaczenia godeł na poziomie odbioru dosłownego oraz symbolicznego. Badaczka zwróciła również uwagę, choć bez odniesienia w rozdziałach, na poziom artystyczny zabytków, który świadczył o pozycji cechów. W kolejnej partii książki - pod nieścisłym nagłówkiem odnoszącym się do literatury - zestawiono wykaz źródeł archiwalnych oraz opracowań.

Drugą część recenzowanej pracy stanowi katalog, w którym, jak wskazała A. Pawłowska, „zebrano wszystkie znalezione przez autorkę godła" (s. 19). W większości przypadków dokonano edycji pieczęci. Na kolejnym miejscu znalazły się inne zabytki. Należało się zatem zastanowić, czy korzystniejszą opcją nie byłoby stworzenie jednorodnego katalogu, który dotyczyłby pieczęci cechowych. Warto dodać, że Badaczka nie wskazała żadnej literatury przedmiotu w tej kwestii. W konsekwencji nie odniesiono się do rozwiązań wypracowanych w różnych współczesnych edycjach, szczególnie sfragistycznych.

Układ katalogu składa się z kilku poziomów. W poszczególnych notach katalogowych obiekty zostały uporządkowane według rzemiosł ułożonych alfabetycznie z podaniem numeru bieżącego. Na kolejnym poziomie uszeregowano je chronologicznie w ramach zestawionych alfabetycznie miast. Taki układ pozwala na prowadzenie badań porównawczych wizerunków danej profesji z różnych ośrodków miejskich - jest zatem dobrym rozwiązaniem. W nocie podana jest datacja tłoka według ustaleń Autorki, następnie sposób wykonania odcisków (określony we wstępie do katalogu jako „forma odcisku”), w przypadku zachowanego tłoka pieczętnego dokonano jego opisu, potem umieszczono wymiary pieczęci, w dalszej kolejności podano edycję legendy i opis wyobrażenia. Obok noty zamieszczono barwną lub czarno-białą fotografię (czasem jednak jej nie ma, przykładowo: s. 186, nr 17; s. 205, nr 55; s. 306, nr 260) ${ }^{12}$. Pod zdjęciem podano informacje dotyczące konkretnych odcisków. Składają się na nią sygnatury oraz chronologia dokumentów, przy których znajdują się pieczęcie. W przypadku pieczęci wskazano też literaturę.

Struktura opisu pieczęci wymaga uporządkowania. Autorka dążyła zapewne do wyszczególnienia najważniejszych danych dotyczących poszczególnych pieczęci. Można było zatem wyraźnie rozdzielić cechy wspólne pieczęci oraz cechy indywidualne odcisków wykonanych z konkretnego typariusza. Kolejną generalną kwestią jest datacja pieczęci. Autorka oparła się głównie na elemencie chronologicznym zawartym w legendzie lub w polu pieczęci. Wskazanie go należy zawsze opatrzeć komentarzem. Jest to bowiem zawodna metoda, gdyż daty umieszczone na pieczęciach cechowych nie muszą zawsze odnosić się do momentu sporządzenia typariusza. Spotykaną praktyką było np. przenoszenie tej samej daty ze starszego tłoka na nowy. Daty mogły zatem upamiętniać ważne wydarzenia w życiu cechów ${ }^{13}$. Wniosek ten wspiera również wydana w recenzowanej pracy pieczęć ciesielska z Kamienia Pomorskiego. W polu pieczęci na osobnych tarczach wyryto dwie różne daty, które nie odnoszą się z pewnością do momentu wykonania tłoka (s. 202, nr 48). Autorka zresztą dostrzegła, że daty nie zawsze muszą odpowiadać sporządzeniu tłoka. Pieczęć garncarzy z Kołobrzegu ma w polu pieczęci datę „14/22”. Cechy stylistyczne pieczęci wskazują, że typariusz został jednak wykonany w okresie nowożytnym. Autorka podała ze znakiem zapytania XVII w. (s. 211, nr 68). W podobny sposób postapiła przy pieczęci piekarzy z Dąbia, która w polu ma date „16/07”. Badaczka datowała pieczęć na pierwszą połowę XVIII w. (s. 282, nr 212). W niektórych przypadkach nie jest jasne, co było podstawą datacji tłoka (np. s. 181, nr 7; s. 226, nr 98; s. 296, nr 241). Kolejna kwestia dotyczy edycji zachowanych tłoków. Sposób reprodukowania ich wizerunku w negatywie utrudnia analizę tego, kto był odbiorcą. Brakuje również fotografii całego tłoka wraz z uchwytem, o ile się zachował. Najważniejszy jednak jest zbyt skrótowy opis typariusza. Brakuje czasem informacji o materiale, $\mathrm{z}$ jakiego został wykonany tłok, nie wykonano też pomiaru rantu tłoka. Błędnie określono przeznaczenie typariuszy wyłącznie do laku, podczas gdy stosowano tego typu tłoki również do innych materiałów pieczętnych. Edycja legend napieczętnych została dokonana bez zastosowania rozwiązań wykorzystywanych w różnych opracowaniach sfragistycznych. Transkrypcji napisów napieczętnych dokonano w formie zachowanej na pieczęciach. Nie rozwiązywano zatem skrótów oraz nie uzupełniano zniszczonych fragmentów (np. s. 181, nr 7; s. 270, nr 189; s. 379, nr 411). Wprowadzono jednak znaki na wskazanie położenia poszczególnych członów legendy (np. s. 194, nr 34; s. 353, nr 360) oraz niekiedy opisano słownie początkowe elementy dekoracyjne (np. s. 204, nr 52; s. 344, nr 340).

11 J. Białostocki, Metoda ikonologiczna w badaniach nad sztuka, w: tenże, Pięć wieków myśli o sztuce, Warszawa 1976, s. 254-260; A. D’Alleva, Metody i teorie historii sztuki, tłum. E. i J. Jedlińscy, Kraków 2008, s. 25-31.

12 Technika wykonywania części zdjęć pod kątem, wbrew intencjom Autorki, utrudnia analizę odcisków pieczętnych, przykładowo: s. 193, nr 31 i s. 286 , nr 220 .

13 T. Kałuski, Pieczęcie cechów, s. 91 n. 
Z kwestii szczegółowych zwrócę uwagę, z braku miejsca, tylko na kilka elementów. Pierwszy dotyczy stosowanego przez organizacje cechowe materiału pieczętnego, a także techniki wykonania odcisków. W katalogu nie wskazano barwy wosku, laku ani tuszu (np. s. 178, nr 1; s. 350, nr 353). Błędnie czasami nazwano sposób wykonania odcisków pieczęci. Autorka posługiwała się konsekwentnie terminem „pieczęć opłatkowa” - jednakże na załączonych fotografiach dostrzegalny jest wosk, a nie ciasto. Stąd poprawną nazwą jest określenie „pieczęć odciśnięta przez papier na podkładzie z wosku” (np. s. 296, nr 241; s. 313, nr 277). W katalogu zdarzają się również niedokładne odczyty legend (np. s. 231, nr 108) oraz opisy wyobrażeń napieczętnych (np. s. 199, nr 43). Ponadto wkradł się tu jeszcze błąd związany z mylnym wskazaniem dysponenta pieczęci. Na s. 316, nr 283, opublikowano pieczęć rzeźników, która została już wcześniej wydana i - wbrew opisowi - nie dotyczy cechu w Gryfinie, ale Głogowie ${ }^{14}$.

$\mathrm{Na}$ koniec należy wskazać, że w pracy miejscami zauważalny jest brak dokładnej korekty. Przykładowo, w jednej z not katalogowych dodano sformułowanie o nieczytelnej legendzie, które jest powtórzeniem zapisu z wcześniejszej noty (s. 302, nr 253). Zdarzają się również pominięcia czy nieścisłe sformułowania.

Recenzowana praca pozostawia spory niedosyt. Wątpliwości budzi przede wszystkim sformułowanie przedmiotu badań. Szerokie rozumienie terminu „godło" należało zawęzić do kwestii heraldycznych i omówić je na tle innych znaków cechowych. Dobór źródeł skłania jednakże do wniosku, że najlepszym rozwiązaniem mogło być skoncentrowanie się na pieczęciach cechowych. Tym samym można było pogłębić ustalenia związane z funkcjonowaniem pieczęci w organizacjach cechowych. Zastrzeżenia wywołują również zbyt ogólnikowe zasady edycji przyjęte w katalogu. Należy jednak na koniec docenić trud, jaki Autorka włożyła w zebranie często niepublikowanych dotąd źródeł. Wykazała się również dobrą znajomością narzędzi i wyrobów, które stanowiły podstawową stronę działalności organizacji cechowych, a ich wyobrażenia pojawiały się na różnych zabytkach cechowych.

Tomasz Kałuski

Uniwersytet Śląki w Katowicach

\section{Pažaislio kamaldulių vienuolyno XVIII-XIX a. vizitacijų aktai, wyd. Mindaugas Paknys, Lietuvos istorijos šaltiniai, t. 14, Lietuvus kultūros tyrimų institutas, Vilnius 2019, ss. XXII + 244}

Akta wizytacji, poprzez mnogość zawartych w nich informacji, są jednymi z najważniejszych źródeł do badania dziejów duchowieństwa i kościołów. Doskonale wiedzą o tym litewscy badacze, którzy w 2019 r. wydali w Wilnie kolejną, czternastą część znanej serii Fontes Historiae Lituaniae (lit. Lietuvos istorijos šaltiniai), tym razem poświęconą fundowanemu w 1664 r. klasztorowi kamedułów w Pożajściu. Mindaugas Paknys, jego monografista, zebrał w omawianym tomie wizytacje tego eremu z lat: 1718-1725, 1731-1735, 1739, 1740 (dwukrotna), 1742, 1744, 1746, 1748, 1750, 1756, 1797, 1804, 1819,1821 i 1831. Wydawnictwo to zaplanowano pierwotnie na 2014 r., gdy obchodzono jubileusz 350-lecia klasztoru'. Edycja źródłowa poprzedzona została wyczerpującym wstępem w języku litewskim i jego dwoma streszczeniami po polsku i angielsku. We wstępie omówiono znaczenie akt wizytacji, kontekst powstania klasztoru w Pożajściu, model przebiegu wizytacji przed rozbiorami i później, a także stan zachowania i miejsce przechowywania źródeł. Następnie skupiono się na wyszczególnieniu i opisie publikowanych wizytacji oraz charakterystyce ich przydatności w badaniach. Szkoda, że o dalszych losach klasztoru (skasowanego po powstaniu listopadowym) wspomina się dopiero w streszczeniu ostatniej wizytacji, jednak niestety bez doprecyzowania chronologicznego (s. 201). Całość wieńczą indeksy osób i miejsc.

Omawiane akta wizytacji okresu przedrozbiorowego pochodzą w większości z jedynej znanej księgi protokołów kapituły klasztornej, przechowywanej w odległym Gruzińskim Narodowym Centrum Rękopisów w Tbilisi, gdzie została przewieziona na początku XX w. przez patriarchę Kiriona II. Wizytacja z 1797 r. znajduje się w Bibliotece im. Wróblewskich Litewskiej Akademii Nauk w Wilnie, a najpóźniejsze (1804, 1819 1821, 1831) należą do zbiorów Litewskiego Państwowego Archiwum Historycznego i Kowieńskiego Archiwum Okręgowego (1831). Należy wspomnieć, że nie są to wszystkie wizytacje/raporty o stanie eremu z tego czasu. M. Paknys we wstępie podkreśla, że brakuje wizytacji z XVII i pojedynczych z XVIII w. (s. XI n.). Szkoda, że w dziele, które miało być w zamierzeniu jak najpełniejszym zbiorem akt wizytacji, nie wykorzystano ani nie wspomniano o przekazach znajdujących się w Rosyjskim Państwowym Archiwum Historycznym w Petersburgu, których sygnatury podał w druku Marian Radwan (f. 822, op. 12, d.: 2945: lata 1796-1798, 2947: 1818 r. ${ }^{2}, 3758: 1803$ r., 3762 : 1805 r., 3763: 1812 r. $)^{3}$.

14 Tamże, s. 159 n., nr 43.

${ }^{1}$ R. Witkowski, Pažaislio kamalduliu vienuolyno ir bažnyčios 1797 metu rugpjūčio 3 dienos vizitacija, „Bažnyčios istorijos studijos”, 7, 2014 , s. 196. 2 We wstępie Edytor wspomina, że wizytacja z 2 I 1818 nie jest znana, a tylko wspominana w późniejszej, z 1821 r. (s. XVI, 186). Trudno mi stwierdzić, czy znajdująca się w Petersburgu wizytacja jest tożsama z tą, o której pisał M. Paknys.

${ }^{3}$ M. Radwan, Repertorium wizytacji kościołów i klasztorów w archiwach Petersburskiego Kolegium Duchownego (1797-1914), Lublin 1998, s. 79, 103; zob. też katalog internetowy na stronie archiwum: <https://rgia.su/> [dostęp: 18.09.2020]. 
Akta wizytacji z lat 1718-1756 zostały sporządzone w języku łacińskim, pozostałe - po polsku. Przeprowadzali je wizytatorzy najwyższej rangi - wikariusz generalny z dwójką asystentów (s. XXI), a w okresie rozbiorów - wyznaczeni przez biskupa wileńskiego wizytatorzy (s. XV). Każde źródło poprzedzone zostało krótkim wstępem, w którym niejako wprowadza się czytelnika w kontekst powstania aktu wizytacji oraz wyjaśnia treść tekstu. Akta wizytacji po łacinie nie są obszerne, zwykle nie przekraczają dwóch stron. Instruowano w nich zakonników co do reguł obowiązujących mieszkańców klasztoru. Z kolei wizytacje z czasów zaborów bardziej koncentrują się na gospodarczej sferze działalności eremu. Spośród wszystkich wizytacji jedynie ta z 1797 r. została już wydana w 2014 r. przez Rafała Witkowskiego ${ }^{4}$. Źródła te zawierają wiele cennych informacji o wyglądzie kościoła i klasztoru, budynków folwarcznych i najbliższego otoczenia eremu. Nie pominięto także w późniejszych wizytacjach wyszczególniania osób mieszkających w klasztorze czy pracujących na jego rzecz, co może być bardzo przydatne dla badaczy spoza kręgu historii sztuki.

W edycji zrezygnowano z objaśnień trudniejszych terminów historycznych czy historyczno-artystycznych. W przypisach podano jedynie proweniencję dokumentów, dopiski notowane na marginesach źródła (s. 34) oraz odwołania do prac Wydawcy (s. 33, 36). Nieco szkoda, że nie skorzystano z rozwiązań R. Witkowskiego, który tłumaczył słowa mogące sprawiać trudność czytelnikowi, zwłaszcza obcojęzycznemu. Należy też wyrazić ubolewanie, że nie skolacjonowano przepisanego tekstu z 1797 r. (lub zrobiono to niestarannie) - ten wydany wcześniej przez R. Witkowskiego wydaje się bowiem dużo staranniej przygotowany. Nie zdecydowano się również uatrakcyjnić wydania przez dodanie jakiegokolwiek zdjęcia źródła, co praktykowano w poprzednich tomach, np. 7, 11 i 12.

Przeszkadzać czytelnikowi mogą zdarzające się od czasu do czasu lapsus calami, np. Ilustrissilma zamiast Illustrissima (s. 23), nosras zamiast nostras (s. 35) czy mnogość zwykłych literówek i niekonsekwencji interpunkcyjnych w tekstach polskich, szczególnie w wizytacji z 1797 r. Wyrazy zapisane w sposób niezrozumiały dla Wydawcy lub te, w których znajdują się błędy rzeczowe, zostały przepisane w formie źródłowej, z oznaczeniem: (sic) (s. XVIII). Zrobiono to jednak bez konsekwencji, w niektórych miejscach te kłopotliwe wyrazy oznaczając, w innych zaś nie. Czasem też dziwią słowa, które zostały uznane przez Edytora za warte oznaczenia, np. zakordonowanie, possydowanie, lub miary: dlużyni, szerzyni, wyżyni (s. 215), bo przecież było to słownictwo często używane, odnotowane choćby w słowniku Samuela Bogumiła Lindego 5 .

Skróty używane w źródłach zostały rozwinięte w ostatnim przypisie we wstępie (s. XVIII), choć nie do końca wiadomo, dlaczego nie ułożono ich alfabetycznie i nie umieszczono tam wszystkich skrótów występujących w tekstach. Zabrakło np.: oo. - ojcowie, ww. - wielmożni, WJ - Wielmożny Jegomość, JP - Jegomość Pan oraz skrótów stosowanych na określenie Wielkiego Księstwa Litewskiego (WK, WX). Dodatkowo skrót JW został rozwinięty jako Jego Wieliebny (rusycyzm!) (zamiast: Jaśnie Wielmożny), W zaś jako Wieliebny (!) (zamiast: Wielmożny; s. XVIII). Niewątpliwie słowo „wielebny” odnosi się do osoby duchownej i - jak podpowiada Korpus języka polskiego - jeśli tak odczytywalibyśmy skrót JW, to winien być on raczej rozwinięty jako Jego Wielebność. Dochodzi bowiem do dziwnej sytuacji, w której opisując sumy kapitalne klasztoru w Pożajściu, osobom świeckim przypisano przynależność do stanu duchownego: „Summa dorobkowa zabezpieczona [...] za obligiem [...] przez Wielebnego Stanisława Gieysztora sędziego ziemskiego kowieńskiego wydanym” (s. 225). Na szczęście ten błąd jest chyba tylko omyłką w druku, znalazł się bowiem tylko we wstępie i na s. $225 \mathrm{n}$.

Wskazane niedociągnięcia nie umniejszają wartości tego wydawnictwa, które umożliwia wielowątkową analizę akt wizytacji jednego miejsca, co sprzyja badaniom źródłoznawczym, a także z zakresu historii lokalnej, gospodarczej, geografii historycznej, socjohistorii i na wielu innych obszarach. Należy wyrazić radość, że badacze zarówno klasztoru kamedułów w Pożajściu, jak i całego zakonu po pięciu latach od jubileuszu 350-lecia eremu wreszcie otrzymali cenny i trudno dostępny materiał źródłowy do historii klasztoru zgromadzony w jednym tomie. Szkoda jednak, że nie poświęcono wystarczającej uwagi, by zadbać o szczegóły edytorskie, przede wszystkim o korektę tekstu źródłowego.

Jan Bulak

Uniwersytet Papieski Jana Pawła II w Krakowie

\footnotetext{
${ }^{4}$ R. Witkowski, Pažaislio, s. 193-290.

5 Zob. Senujų Lietuvos Didžiosios Kunigaikštystès kelių aprašymai, oprac. A.A. Baliulis, T. Čelkis, Vilnius 2018; S.B. Linde, Stownik języka polskiego, t. 1, Warszawa 1807, s. 432 (dlużyna, dtużyzna); t. 5, Warszawa 1812, s. 538 (szerzyna, szerzyzna); t. 6, Warszawa 1814, s. 554 (wyżyna).
} 